UNIVERSIDADE DE SÃO PAULO

FACULDADE DE FILOSOFIA, LETRAS E CIÊNCIAS HUMANAS - FFLCH

DEPARTAMENTO DE FILOSOFIA

PROGRAMA DE PÓS-GRADUAÇÃO EM FILOSOFIA

JULIANO GARCIA PESSANHA

\title{
Peter Sloterdijk:
}

virada imunológica e analítica do lugar

Versão corrigida

São Paulo

2017 
JULIANO GARCIA PESSANHA

\author{
Peter Sloterdijk: \\ virada imunológica e analítica do lugar
}

Tese apresentada ao programa de Pós-Graduação em Filosofia do Departamento da Faculdade de Filosofia, Letras e Ciências Humanas da Universidade de São Paulo, para obtenção do título de Doutor em Filosofia sob a orientação do Prof. Dr. Ricardo Fabbrini.

Versão corrigida

São Paulo

2017 
Autorizo a reprodução e divulgação total ou parcial deste trabalho, por qualquer meio convencional ou eletrônico, para fins de estudo e pesquisa, desde que citada a fonte.

Catalogação na Publicação

Serviço de Biblioteca e Documentação

Faculdade de Filosofia, Letras e Ciências Humanas da Universidade de São Paulo

\begin{tabular}{|c|c|}
\hline \multirow[t]{3}{*}{ Pp } & $\begin{array}{l}\text { Peasanha, Juliano Garcia Peananha } \\
\text { Peter sloterdijk: virada imunol6gica e analitica do } \\
\text { lugar / Juliano Garcia Peananha Peananha ; } \\
\text { orientador Ricardo Namcimento Fabbrini Fabbrini. - } \\
\text { Säo Paulo, 2016. } \\
\text { f. }\end{array}$ \\
\hline & $\begin{array}{l}\text { Teae (Doutorado) - Paculdade de Filoaofia, Letras } \\
\text { e Ciencias Humanas da Univeraidade de Säo Paulo. } \\
\text { Departamento de Filomofia. Area de concentraçăo: } \\
\text { Filomofia. }\end{array}$ \\
\hline & $\begin{array}{l}\text { 1. Filosofia contemporsinea. 2. Imunidade. } 3 \text {. } \\
\text { sloterdijk. 4. Heidegger. } 5 \text {. Epaço. I. Fabbrini, } \\
\text { Ricardo Nascimento Fabbrini, orient. II. Titulo. }\end{array}$ \\
\hline
\end{tabular}


PESSANHA, Juliano Garcia. Peter Sloterdijk: virada imunológica e analítica do lugar. 2016. Tese (Doutorado) - Faculdade de Filosofia, Letras e Ciências Humanas. Departamento de Filosofia, Universidade de São Paulo, São Paulo, 2016.

Tese apresentada ao programa de Pós-Graduação em Filosofia do Departamento da Faculdade de Filosofia, Letras e Ciências Humanas da Universidade de São Paulo, para obtenção do título de Doutor em Filosofia sob a orientação do Prof. Dr. Ricardo Fabbrini.

Aprovado em:

Banca examinadora

Prof. Dr. Instituição:

Julgamento: Assinatura:

Prof. Dr. Instituição:

Julgamento: Assinatura

Prof. Dr.

Julgamento: Instituição:

Prof. Dr. Julgamento: Instituição: Assinatura:

Prof. Dr. Instituição:

Julgamento: Assinatura: 
Dedico este trabalho à obra de Peter Sloterdijk, que me curou do romantismo do aberto e me fez olhar para o mundo de um modo mais lúcido. 


\section{Agradecimentos}

A meu orientador Ricardo Fabbrini, pelo desafio proposto de deslocar-me do terreno filosófico trabalhado literariamente para o filosófico com pressupostos acadêmicos.

A Ângela Rocha, minha amiga e professora da FAU-USP, leitora entusiasmada de Peter Sloterdijk, com quem travei árduos debates sobre a obra do filósofo alemão e longas leituras conjuntas nos últimos cinco anos.

A Cláudia Vasconcellos, interlocutora há duas décadas, ao José Feres Sabino, amigo e germanista, a quem devo a partilha de seminários filosóficos presenciais e telefônicos, e a Jucimara Tarricone, pela leitura atenta deste trabalho. E também a Rafael Ranalli, colega e interlocutor desde os tempos de graduação em filosofia na USP.

A Oneide Alves Martini e Paulina Ghertman, minhas mães ontológicas, a primeira índia e a segunda judia, que me deram amparo e dividiram comigo a compreensão do pensamento de Sloterdijk. E a Claudio Fernandes e Nele Azevedo, que também fazem parte de minha família de adoção.

A Carla Koch, minha professora, pela leitura conjunta de Esferas I em alemão.

Agradeço também aos amigos e alunos, com quem pude digerir e expor - não sem conflitos e resistências - os livros de Sloterdijk, entre eles, e espero não estar esquecendo alguém importante: Andréa Bernardelli Iamaguchi Sherzer; Arthur Tufolo; Beto Gabrilli; João Augusto Paiva; Lucas Nakandacare; Luciana Necchi R. Dallari; Luiz Carlos Garcia Vieira; Márcia Rosenfeld; Marcelo Rocha; Marcos Salém Vasconcelos; Paulo Germano Marmorato; Regina de Barros Carvalho; Patrícia Brandstatter; Vivian Montag; Wagner Batista Bezerra e William Wagner Winkler.

A Márcio Suzuki e Valter José Maria Filho, pelo encorajamento em momentos difíceis, sobretudo quando a saúde declinou.

A meu pai, Antonio Luiz Serpa Pessanha, pelos dias silenciosos na chácara de São Roque, e a minha prima Denise Nunes Garcia, pelo empréstimo do apartamento no Guarujá, onde várias dessas páginas foram escritas.

A Luciana Araujo Marques, minha companheira, que testemunhou, não sem grande perplexidade, a conversão e a queda do poeta aristocrático do pedestal do negativo para o chão do pesquisador comum. 
PESSANHA, J. G. Peter Sloterdijk: virada imunológica e analítica do lugar. 2016. 147 f. Tese (Doutorado) - Faculdade de Filosofia, Letras e Ciências Humanas. Departamento de Filosofia, Universidade de São Paulo, São Paulo, 2016.

\section{Resumo}

No Brasil, ainda são poucos os estudos sobre o pensamento do filósofo alemão Peter Sloterdijk, que é, certamente, o maior herdeiro da linhagem filosófica de Friedrich Nietzsche e Martin Heidegger. Um herdeiro heterodoxo, que, mantendo o pensar no mesmo patamar de seus mestres, os corrige e desafia. Esta tese, que privilegia a discussão de Sloterdijk com Heidegger, apresenta resumidamente o Projeto Esferas, composto por três volumes (Esferas I, II e II), e sugere que esta obra representa uma virada paradigmática com consequências muito férteis e desafiadoras para a filosofia contemporânea. O fio condutor da leitura empreendida é a ideia dos receptáculos conformadores de mundo e a apresentação sucessiva das principais morfologias (Bolha, Globo, Espuma), que correspondem a cada um dos volumes dessa trilogia, e respondem à pergunta: "onde estamos quando estamos no mundo?". Se a microesferologia equivale a uma analítica do lugar íntimo (Bolha), problematizadora do ponto de partida da psicanálise tradicional, a macroesferologia (Globo) procura desvendar a forma do mundo na era metafísica. Já a dissolução da superimunidade ideal e a correlata crise da forma política imperial abrem o campo da modernidade como uma era na qual o "onde" é esclarecido pela forma da espuma. A analítica da espuma, enquanto ontologia de nós mesmos (pois somos onde estamos!), oferece um diagnóstico relevante do nosso lugar atual: o palácio de cristal e suas imunidades técnicas, a residência na superinstalação do interior capitalista.

Palavras-chave: Sloterdijk; Heidegger; espaço; imunidade; filosofia contemporânea. 
PESSANHA, J. G. Peter Sloterdijk: Immune Turn and Analytics of the Place. 2016. 147 f. Tese (Doutorado) - Faculdade de Filosofia, Letras e Ciências Humanas. Departamento de Filosofia, Universidade de São Paulo, São Paulo, 2016.

\begin{abstract}
The works of German philosopher Peter Sloterdjik are attracting growing worldwide interest. To date, Brazil has produced very few critical essays on this thinker who is unquestionably the major heir of the philosophical tradition inaugurated by Friedrich Nietzsche and Martin Heidegger - a heterodox heir who, while keeping thought on the same basis as his masters, dares to correct and challenge them. This thesis, which gives priority to the discussion between Sloterdijk and Heidegger, provides a brief introduction to three-volume Sphären (Spheres I-III) and suggests that it represents a paradigm shift with highly challenging and fertile consequences for contemporary philosophy. The common thread running through his investigations is the notion of world-forming receptacles and the successive presentation of the major morphologies (Bubble, Globe, Foam) comprising each of the volumes of this trilogy in response to the question: "Where are we when we are in the world?" If microsphereology is equivalent to an analytics of intimate space (Bubble) which casts doubt on the cornerstone of traditional psychoanalysis, macrosphereology (Globes) unveils the morphology of the world in the metaphysical era. In turn, the dissolution of the ideal super-immunology and the associated crisis in the imperial model of politics pave the way for modernity, an era in which the answer to "where" is clarified by the foam. The analytics of the foam as an ontology of our own selves (since what we are starts from where we are!) offers a relevant diagnosis of our current location: the palace of crystal and its technical immunities, the dwelling in the super-installation of the capitalist interior.
\end{abstract}

Keywords: Sloterdijk; Heidegger; space; immunity; contemporary philosophy. 


\section{Sumário}

Introdução.....................................................................................................................................9

Capítulo 1: Analítica das Bolhas.........................................................................13

1.1 Esferologia e paradigma imunológico............................................................... 14

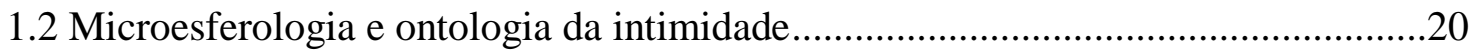

Adendo I: sobre a diferença entre estar exposto e estar incluído...................................35

1.3 Outras considerações microesferológicas.............................................................43

Capítulo 2: Analítica de Macroesferas................................................................48

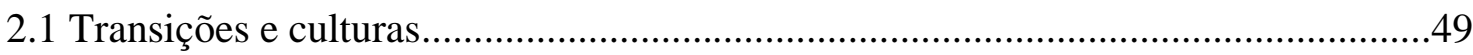

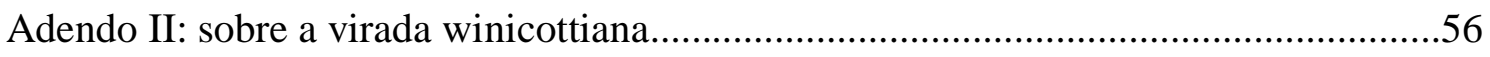

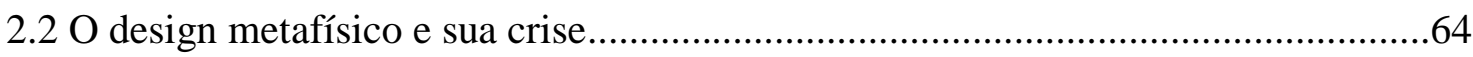

Capítulo 3: Analítica das Espumas....................................................................72

3.1 Explicitação crescente e ontologia da atualidade.................................................73

Adendo III: sobre os extremismos de Heidegger lidos por Sloterdijk ...........................81

3.2 Explicitação sloterdijkiana do acontecimento ontológico........................................90

Capítulo 4: Era Histórica e Pós-histórica............................................................103

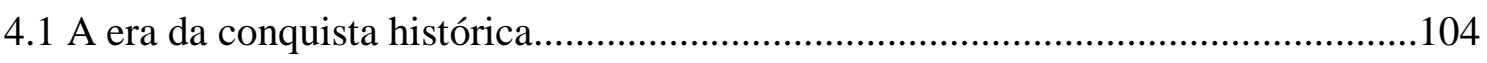

Adendo IV: sobre normalidade, situação-limite e decisão......................................119

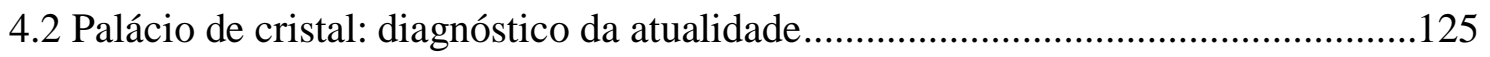

Conclusão.

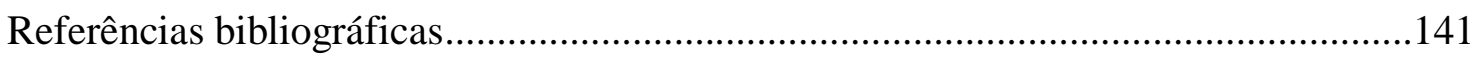




\section{Introdução}

Sloterdijk é um filósofo que conta uma história abrangente do acontecer humano e a chave desta é o espaço. A trilogia Esferas busca responder a questão de como é que os seres humanos conformaram suas casas-mundo desde os primeiros grupos até os dias de hoje. A resposta a esta pergunta e a correlata obsessão morfogenética nela contida obrigam o filósofo de Karlsruhe a constituir narrativas que retrocedam até os eventos mais primitivos. Diferentemente da obra da maioria dos filósofos, a sloterdijkiana não começa pela Grécia, mas pela "pré-história” (embora Sloterdijk não utilize este termo), e por isso a quantidade de materiais e fontes que ela reúne é tão colossal que aqui se optou por uma exposição abreviada da esferologia, privilegiando a interlocução de Sloterdijk com Heidegger. Essa escolha não é arbitrária, pois o pensador da Floresta Negra é de fato a figura central com a qual os três volumes (Bolhas, Globos, Espumas) dialogam constantemente. O único filósofo que se poderia equiparar a Heidegger na importância que tem para o pensamento sloterdijkiano é Nietzsche, mas a presença deste na esferologia é mais discreta, e uma tese que versasse sobre o autor de Assim falou Zaratustra e Sloterdijk teria de focar mais nos livros de juventude deste último como Crítica da razão cínica (1983) e O pensador em cena: o materialismo de Nietzsche (1986), e em posteriores ao projeto Esferas, caso de Ira e tempo (2006) e Deves transformar tua vida (2009), nos quais o diálogo com Nietzsche é mais intenso.

Se a discussão com Heidegger pontua estrategicamente a exposição sintética que esta tese faz deste "romance dos espaços" (SLOTERDIJK, 2009a, p. 191), outra linha organizadora assumida foi a de privilegiar algumas das críticas que Sloterdijk dirige aos principais pensadores do século XX. Esse procedimento foi adotado não para salientar o caráter polêmico das intervenções de Sloterdijk, mas para enfatizar como uma nova maneira de colocar as questões modifica e problematiza a leitura de vários autores, obrigando, assim, os leitores de filosofia ao esforço de releituras. Tais esforços são penosos, pois muitas vezes eles agem contra nós mesmos, ao retirar o amparo e a tranquilidade que julgávamos ter encontrado em algum grande autor da filosofia ou mesmo em alguma constelação de tais autores. O modo como Peter Sloterdijk responde às questões “o que é estar dentro?”, “o que é estar no mundo?”, “onde estamos quando estamos no mundo?" é forte e inovador o suficiente para ocasionar esse tipo de reviravolta problematizante. Não há dúvida que há uma certa resistência à sua obra entre os brasileiros, dado o seu caráter ousado e também pela maneira renovadora de articular 
as epocalidades e o diagnóstico do presente. No que tange este último tópico, o diagnóstico da atualidade e o acerto do relógio epocal - ambos constituem o terceiro leitmotiv desta tese -, a leitura sloterdijkiana é instigante e geradora de disputa, pois muitos pensadores que ainda hoje comandam o debate filosófico são vistos por Sloterdijk como pertencentes ao ambiente já superado do extremismo do entre guerras.

Essas palavras preliminares servem para situar este trabalho como uma modesta contribuição à tarefa de recepção do pensamento do ex-reitor da Holschule für Gestaltung, de Karlsruhe, no Brasil, onde até agora vigora um certo silêncio. É, portanto, com fim introdutório que este trabalho foi dividido em quatro capítulos. Se os três primeiros acompanham parte do conteúdo dos volumes da trilogia Esferas, o capítulo 4 não visa mais que apresentar os principais tópicos abordados em Palácio de cristal: para uma teoria filosófica da globalização, uma vez que as primeiras 170 páginas deste livro constituem um apêndice ao Esferas II (Globos) e as outras 110 restantes podem ser lidas conjuntamente com o volume III (Espumas), como um complemento ao diagnóstico da atualidade. Em termos puramente quantitativos, esta tese, que prima pela concisão e privilegia o recorte das três linhas citadas acima, sintetizou mais detidamente cerca de 1400 páginas das 2300 que perfazem a trilogia e o livro sobre o palácio de cristal, embora a totalidade da obra de Sloterdijk estivesse o tempo todo no horizonte da pesquisa. Procurou-se nesse sentido, abordar os núcleos mais filosóficos, deixando de lado certas exposições históricas, mas é o leitor quem poderá julgar se isto foi bem logrado.

Uma das dificuldades de se escrever sobre Sloterdijk é que ele escreve muito bem e dispõe de uma admirável inteligência narrativa cuja peculiaridade de estilo é formular uma mesma questão de várias maneiras e com muitas expressões sinonímicas. Diante disso, o seu leitor e comentador sente-se muitas vezes reduzido à tarefa de selecionar os melhores momentos e recortar as expressões mais felizes. Foi para diminuir o risco desta tese se tornar apenas uma suma das pérolas aforísticas, encontráveis nos longos parágrafos sloterdijkianos, que se optou por aliar à reconstrução de alguns momentos da obra, adendos nos quais se ousa algumas hipóteses e teses que não são apenas tautológicas em relação ao já escrito pelo próprio Sloterdijk. Assim, o adendo I sugere que certas posições da filosofia francesa padecem de um radicalismo que se tornou envelhecido; o adendo II afirma que o nome de Donald Winnicott pode servir de senha para a compreensão do que está envolvido na virada esferológica em relação às obras anteriores de Sloterdijk; o adendo III expõe com certa 
liberdade a posição de Heidegger a fim de lhe delatar o extremismo; o adendo IV retoma o tema da situação-limite (extrema) para reforçar a discussão com Heidegger tratada no adendo III, estendendo-a a Carl Schmitt. Em todos eles, trata-se de tomar alguma distância da obra estudada para evitar uma leitura muito colada ou simbiótica. Nos adendos arrisca-se, portanto, o dizer de alguma coisa que o próprio autor já não tenha dito em várias obras de entrevista e de esclarecimento, nas quais ele se autocritica, se autointerpreta e se inscreve ou rompe com determinadas filiações.

Se todos os filósofos repetem sempre aquelas seis ou sete palavras básicas que constituem o vocabulário das grandes filosofias - e o jargão não é apenas um problema de Heidegger, como pensava Adorno -, Sloterdijk foge à regra, porque ele amplia e traduz em imagens, narrativas e ilustrações o que seria o jargão-chave imunológico. $\mathrm{O}$ escopo desse jargão no grande "romance dos espaços" é apresentar a conformação dos mundos e acompanhar o seu surgimento a partir de experiências decisivas. Nada menos especulativo e menos abstrato que o dizer desses acontecimentos numa linguagem abridora da filosofia à compreensão do não iniciado e que corrobora o dito com imagens. Daí o problema do comentador: ele corre o risco de virar copista ou aparecer com lanternas para iluminar páginas que já estão sob a luz do meio-dia.

Feitas essas ressalvas, pode-se então enunciar o conteúdo básico de cada um dos capítulos. O capítulo I, incluído o adendo, expõe o repertório filosófico básico da microesferologia e defende a tese de que esse novo ponto de partida equivale a uma quebra paradigmática, que reposiciona as filosofias precedentes. Daí a insistência nas divergências com Heidegger e Freud, além de Lacan, Blanchot, Levinas, Deleuze e outros autores franceses, bem como uma breve apresentação de uma crítica da teoria crítica na figura de Adorno. ${ }^{1}$

Se o capítulo 1 apresenta a arquitetura dos mundos pequenos, o segundo o faz com a passagem para o desenho do mundo grande e expõe sucintamente a morfologia do amparo metafísico. O adendo sobre Winnicott retoma as críticas sloterdijkianas a Freud e a Lacan e a antropologia da carência.

\footnotetext{
${ }^{1}$ É certo que a natureza das discordâncias em relação a cada um dos autores citados varia muito. O caso paradigmático de Heidegger, criticado e aproveitado, mostra que Sloterdijk muitas vezes se apropria de aspectos de um pensamento, rejeitando outros. Se a teoria crítica é criticada em suas bases, como se procurará mostrar nos capítulos 1 e 4, pensadores como Deleuze são simultaneamente questionados e elogiados. Para ficar apenas no exemplo deste último, a correção sloterdijkiana esboçada em Esferas I, tratado no capítulo 1 desta tese, acerca do teorema do rosto, é compensada com o elogio, extensivo a Nietzsche, à posição do filósofo francês, no que diz respeito a uma antropologia não miserabilista da existência exuberante, no final de Esferas III.
} 
Já o capítulo 3 trata da forma do mundo após a implosão do design metafísico e expõe a nova forma poliesferológica e os desenhos técnicos de imunidade, privilegiando a discussão com Heidegger. No adendo sobre este último, e para além dele, mostra-se a diferença entre o pensador da negatividade e do resguardo da condição mistérica e aquele que acompanha a marcha explicitante e desencantadora da modernidade sem nenhum lamento ou desejo de resistência. Aliás, termos como esses desaparecem no vocabulário sloterdijkiano, pois o processo de objetivação explicitante é lido como facultador de próteses que aumentam a leveza da vida humana, permitindo um repertório maior de mimos e de conforto.

O quarto e último capítulo reconstrói, em linhas gerais, o livro Palácio de cristal: para uma teoria filosófica da globalização. Se o subcapítulo 4.1 narra as peripécias da globalização da terra e as aventuras da desinibição agressiva do europeu, a parte 4.2 trata da globalização consumada e do declínio da práxis. Nele retoma-se a discussão com Heidegger em torno dos motivos leveza e peso ou superabundância e facticidade, e indica-se a direção de uma crítica ao pensamento de Walter Benjamin. Essa crítica - como é o caso de todas as outras recolhidas nesta tese - mostra o esforço de Peter Sloterdijk para se afastar do radicalismo e da hermenêutica dos extremos, bem como de todas as variantes do pessimismo ontológico, e formular as bases de uma antropologia não miserabilista e uma relação mais afirmativa com a modernidade e o regime das espumas. Acrescenta-se neste capítulo um adendo sobre normalidade, situação-limite e decisão, no qual são apresentadas críticas a Heidegger e Carl Schmitt. 
1. ANALÍTICA DAS BOLHAS 


\subsection{Esferologia e paradigma imunológico}

Peter Sloterdijk nasceu em 1947 na Alemanha. Veio ao mundo, portanto, no imediato pós-guerra. Nascido nessas condições, com o indescritível "às costas e tatuado com um horror incondicional" (SLOTERDIJK, 2006, p. 49), ele era um ótimo candidato a realizar na filosofia uma espécie de virada imunológica. Quem nasce em meio a uma tradição de destruição está existencialmente apto a levantar questões topológicas em torno do habitável: onde estão os homens? Em que consiste, afinal, este oxigênio que denominamos cultura no interior do qual existimos e respiramos? Em que condições um ser humano floresce e vem ao mundo ou fracassa e fica detido nos espaços infernais?

Nesse sentido, Sloterdijk é talvez o herdeiro da concepção nietzscheana do filósofo como médico da cultura: um médico hiperlúcido, que olha as culturas do exterior e que "possui o dom obscuro dos vampiros" (SLOTERDIJK, 2007, p. 175), e que, embora parta metodologicamente de uma melancolia radical, não toma o partido da exterioridade. Ao contrário de grande parte das filosofias do século XX, Sloterdijk está interessado em pensar os espaços interiores, sua arquitetura, seu design e sua conformação, e isto pela simples razão de que os seres humanos, desde que temos notícias deles, sempre existiram no interior desses espaços.

Seres humanos são arquitetos de espaços interiores. Jamais viveram numa "relação imediata com a natureza ou na proximidade dos fatos" (id., 2003, p. 52), mas

sempre no interior de receptáculos autogerados, onde tudo o que é encontrado está submetido a climatizações simbólicas, calibragens semiológicas e atmosférico-afetivas. A cultura como "forma imunológica" nasce precisamente de um pacto contra a exterioridade, e a tarefa que Sloterdijk se impõe é a de descrever esses receptáculos. Tal descrição levada a cabo na trilogia Esferas oferece uma narrativa filosófica poderosa. Esse relato permite que localizemos nosso endereço epocal em termos de morfologia imunológica. Ele é poderoso, pois o pensador de Karlsruhe diferencia morfologias prémetafísicas, metafísicas e a da modernidade, o que significa dizer que o relato sloterdijkiano abrange desde os primeiros hominídeos na savana africana a erguer suas primeiras tendas-mundo, passando pelo sábio grego a contemplar a maravilha da ordem cósmica na aurora da primeira globalização até um homem introduzido numa cápsula astronáutica ou em um aparelho de tomografia computadorizada. 
Em termos da história da filosofia mais recente, a descrição dos receptáculos imunológicos equivale à realização de uma analítica existencial do lugar. Uma analítica do ser-em. Sloterdijk paga assim uma nota promissória que Heidegger havia deixado pendente por causa de sua excessiva alergia ao mundo estabilizado e aos espaços domados. ${ }^{2}$ Como Hannah Arendt, Sloterdijk olha estrábica e complementarmente para Heidegger e, reivindicando a herança bachelardiana, mostra que o pensador da Floresta Negra não pôde discriminar entre o pequeno e o grande. O homem não é um ser jogado no mundo para dentro de uma única grande esfera impessoal, mas alguém que é parido, chega ao mundo e transita de um espaço a outro. No início sai do calor sonoro da piscina amniótica e da sustentação do íntimo placentário para encontrar o colo e o berço. Descrever essa transição do pequeno ao grande é a tarefa da Esferologia. As esferas comandam as migrações e o que é transferido do mundo miúdo (microsfera) ao imenso (macrosfera).

Esferas I tem o subtítulo Bolhas e se detém nos espaços microsféricos, o que equivale a desenvolver uma ontologia do íntimo e das relações simbióticas. Esses espaços jamais são ocupados por um só elemento. Se eu conto a alguém que vi um bebê entrar no mar, imediatamente o meu interlocutor perguntará quem o carregava, quem estava com ele, pois não se vê um bebê sozinho por aí. Ora, a analítica sloterdijkiana pretende fazer jus à radicalidade e à intensidade desse com. Esse com é, na verdade, um estar em, um estar dentro. Ele é uma espacialidade peculiar, e quem não a adentrou não pôde se sentar à mesa dos humanos. Definhou ou abortou de susto. Rasgou-se na exterioridade. Ninguém precede seus animadores, aliados e sustentadores. Descontados alguns pastores do ser, corpos sem órgãos e outros tipos de seres oco-abismais, a maioria daqueles que são infans recebe animação e preenchimento ao incorporar e canibalizar o sossego e o calor benfazejo dos sustentadores. Também a intimização e a familiarização com o mundo dependem da zona imunológica entre os aliados, pois é somente aí que aquilo que chega e vem ao encontro não emerge numa indomável fulguração alética, mas na hospitalidade do "como se tivesse sido criado por mim" (leiase: "criado" entre os aliados).

\footnotetext{
${ }^{2}$ Heidegger é um pensador do movimento originário e, exatamente por pensar nessa posição, ele é um "pouco cego" para o mundo instituído. "Seu pensamento originário ou o que vem a ser quase sua proeza (Tathandlung) é o salto ou o lançar-se em uma circunstância na qual não encontra nem em si mesmo nem sob seus pés, outra coisa a não ser mobilidade. No seu caso, a cinética precede a lógica, ou se se permite o giro paradoxal, o movimento é seu fundamento. O impulso de sua palavra é expressar a mobilidade, ou melhor, alcançar com a palavra-movimento a mobilidade verdadeira e inevitável. Consequentemente, merece ser caracterizado como nenhum outro filósofo antes dele, pela incomum e não bem esclarecida fórmula: o pensador no movimento" (apud CORDUA, 2008, p. 48).
} 
Sloterdijk é um pensador do Dentro e dos espaços interiores. Para ele, o próprio nascimento é passagem de um interior mais estreito a outro mais amplo. No começo, como já dito, o Dasein concretamente qualificado sai do líquido onde está acompanhado e sustentado pelo primeiro com, a placenta, para, ao sair, encontrar o abraço da mãe. Transita-se, assim, de um primeiro estar-dentro íntimo para um outro, uma mãe pensada aqui como um "lugar, uma forma-receptáculo, uma estrutura imunitária espacial" (id., 2007 , p. 136). Se muitos veem no umbigo a marca de uma orfandade radical, para a Esferologia ele é o rastro de um outro que nos sustentou, o sinal de sua retirada causadora da individuação. Todo o individualismo moderno se fundamenta na mentira de que nascemos sós, quando, na verdade, sempre chegou um outro junto conosco. Nosso acompanhante, nosso pré-objeto mais íntimo, é destruído e dispensado, ao contrário das culturas nas quais a placenta é guardada na casa, transformada em amuleto ou colocada sob árvores específicas, assinalando assim a lembrança contínua do primeiro aliado.

A partir do corte do primeiro com, perco a comunhão de sangue para nascer no ar e ganhar respiração e voz para pedir o leite. Como se vê, migramos de dentro de uma esfera íntima para uma outra, a mãe, na condição de recipiente imunológico de proteção contra o exterior. Esse é o ponto decisivo: se o ser humano é hiperexposto ao exterior e ao estranho, ele enlouquece. A psicose é a marca de uma mudança de envoltório fracassada. Se não há um outro que na condição de anfitrião nos dê as boas-vindas e faça um "bilu-bilu" na aletheia, nos inserindo paulatinamente no mundo, ficamos resfriados no susto e no pavor do exterior. As esferas acontecem entre os seres humanos como "criações espaciais, imunologicamente eficientes para seres como nós em que opera o exterior" e o estranho (id., 2003, p. 37). Esse pensamento central já não abandona Sloterdijk e é a partir dele que se poderá redescrever as culturas e a própria filosofia como ensaios de arquitetura e design imunológico: elas visam conseguir no grande algo da proteção obtida no pequeno.

Começar do pequeno é começar do começo. É substituir o estar-lançado (Geworfenheit), um tanto abstrato de Heidegger, pela temperatura e cor do berço da criança. É lançado onde? Como é o berço? Há umidade e mofo naquele quarto? Como é seu aliado? Sloterdijk toma a sério a crítica bachelardiana ao Ser e tempo ${ }^{3}$ e desloca a

\footnotetext{
${ }^{3}$ Antes de ser "jogado no mundo, como o professam os metafísicos apressados, o homem é colocado no berço da casa. E sempre, nos nossos devaneios, ela é um grande berço. Uma metafísica concreta não pode deixar de lado este fato, esse simples fato, na medida em que ele é um valor, um grande valor ao qual
} 
atenção para o nascimento, frequentemente esquecido na filosofia, que opta por ressaltar a mortalidade. ${ }^{4}$ Começar pelo início implica se lembrar de que todos fomos bebês, nascemos frágeis e precários, e que não chegaríamos a nós mesmos e ao mundo sem a intermediação de outros seres humanos que nos complementam e nos sustentam. Esferas I mergulha no mar matriarcal pré-subjetivo e pré-objetivo a fim de iluminar os passos - e os "passos" aqui são sopros, mergulhos extáticos no mais próximo e incorporações produtivas - já necessariamente acontecidos quando reivindicamos o título de sujeito ou nos declaramos cidadãos do mundo. Ao contrário de seu mestre (Heidegger), que começa sua analítica por uma cotidianidade na qual adultos já se encontram pretensamente inseridos e familiarizados em um sentido público, Sloterdijk recua até o quilômetro zero a fim de mostrar quais são os processos de enraizamento que possibilitam a familiarização e a intimização com o mundo: a descrição fenomenológica desses "processos" é o tema da microesferologia Bolhas.

Já Esferas II tem o subtítulo Globos, e nele Sloterdijk estuda a grande época metafísica e o seu projeto imunológico específico, a saber, que o ente no seu todo, incluídos nós mesmos nele, está Dentro: tudo o que é se encontra protegido e amparado sob o império de uma forma organizada. Tudo está localizado, contido e envolvido por uma periferia máxima, e o centro irradiador persiste vinculando e nutrindo tudo o que é. Como escreve Sloterdijk,

com a imagem da esfera se estende o evangelho da inclusão total: nada real pode estar verdadeiramente fora, nenhuma coisa existe separada do corpus e continuum do uno, a meditação filosófica do envolvente deixa claro [...] que um universo, por maior que se suponha, pode ser representado como espaço interior e como esfera compartilhada de força e sentido (SLOTERDIJK, 2004a, p. 107).

Para o homem da era metafísica, estar no mundo equivale a um estar-em-Deus. Platão é o designer dessa nova situação, ele é o "imunólogo chefe da era metafísica" e o seu desenho perdurará bimilenariamente. Esferas II descreve ao longo de mais de novecentas páginas as vicissitudes da forma imunológica globo, desde sua aurora na

voltamos nos nossos devaneios. O ser é imediatamente um valor. A vida começa bem, começa fechada, protegida, agasalhada no regaço da casa" (BACHELARD, 2012, p. 26).

4 "Intimidados e fascinados pela sua mortalidade, passam por cima do ter-nascido como por cima do que há de mais casual. O cogito da morte sufocou mesmo o mínimo começo de um cogito do nascimento... até a Heidegger e até hoje" (SLOTERDIJK, 2002a, p. 146). Uma das exceções neste longo percurso do esquecimento da natalidade encontra-se em Hannah Arendt cujo pensamento pode ser lido em muitos aspectos como resposta aos déficits e pontos-cegos de Heidegger. Cf., por exemplo, "A crise na educação" em Entre o passado e o futuro. 
primeira religião do logos, passando pela elaboração do cristianismo nos termos prévios da ontologia da esfera - afinal, a forma omni-envolvente da esfera, objeto da veneração dos sábios gregos, já lograra o seu objetivo imunológico de exorcizar a exterioridade bem antes da vinda de Cristo - até a tragédia morfológica, resultante de um processo de infinitização de Deus e do universo, que conduz à modernidade.

Para nós, modernos, é difícil recuperar a experiência do que seria estar amparado por um todo envolvente e por abóbodas celestes. Há mais de 450 anos que o universo fechado deu lugar ao mundo infinito, e a palavra cósmico perdeu a letra "s". Nós compensamos essa perda com a construção de um mundo artificial civilizador (recentemente uma empresa telefônica se apresentava na TV como um toldo envolvente para a humanidade) e com a tecnificação da imunidade. Com o colapso da esfera, o homem moderno é expulso de Deus e encontra uma exterioridade generalizada. Ele já não está mais Dentro, mas na superfície rugosa do globo terrestre e é ele mesmo quem deverá construir seus sistemas imunológicos. Essa nova situação, esse ex-centrismo não satânico que constitui a modernidade, liberou os homens do imobilismo e os lançou no movimento e na ação. O cálculo e o seguro entram no lugar de Deus, e a palavra fundamental da era moderna é descobrimento, algo que designa o "superacontecimento da tomada e registro da Terra e que se refere ao conjunto de práticas mediante as quais o desconhecido se transforma em conhecido, o não representado em representado ou registrado" (id., ibid., p. 781).

Com a morte da esfera abrangente, e sua geometria de segurança, começa a entrar em cena o planeta Terra e o processo de globalização propriamente terrestre. Isso significa que para Sloterdijk a primeira globalização é grega e

reside na racionalização da estrutura do mundo pelos antigos cosmólogos, que, pela primeira vez, com seriedade conceitual, melhor dizendo, com seriedade morfológica, construíram a totalidade do ente sob forma esférica, tendo oferecido essa imagem ordenada à consideração do intelecto (id., 2008b, p. 18).

Já a globalização terrestre equivale, grosso modo, ao período que vai de 1492 até 1945, e que Sloterdijk considera terminado. Essa globalização não é mais um tema para geômetras e sábios, mas problemas "a ser resolvidos pelos cartógrafos e aventura a ser vivida pelos marinheiros" (id., ibid., p. 26). A essa segunda globalização segue-se a eletrônica e o envolvimento da órbita terrestre por satélites. Esse último período (terceira globalização), que é aquele em que vivemos hoje, Sloterdijk chamará de 
“palácio de cristal”, expressão cunhada por Dostoiévski em 1862, ou global age ou ainda pós-história. Em termos imunológicos, o palácio de cristal é a transposição do "mundo exterior enquanto todo para uma imanência mágica, transfigurada pelo luxo e cosmopolitismo" (id., ibid., p. 185). Nesse estágio palaciano, o que vigora não é assunto para geômetras nem cartógrafos e marinheiros ousados, mas climatólogos, ecólogos e economistas políticos competentes.

Seguindo a obsessão morfológica que Sloterdijk conta ter herdado de Spengler, Esferas III trata do nosso próprio endereço epocal e por isso leva o subtítulo Espumas. Essa imagem diz de um mundo onde já não estamos mais reunidos e conectados com um reator central do ser e muito menos que pudéssemos constituir uma confraria de coanimados pelo sustentador nuclear. Não. Na espuma nos movemos por pequenas bolhas descentradas, maiores ou menores, e tanto já não podemos acessar uma visão clara do todo quanto aquilo que nos sustenta e nos anima - conformando um espaço interior - será sempre pura exterioridade para o vizinho e para o outro. Há ainda o risco de resfriar e virar um "ponto depressivo isolado" por falta de força conformadora de espaço psíquico.

O regime das espumas é poliesferológico e ele se inicia após a implosão do globo e a morte de Deus. Ele implica uma ontologia pluralista e uma espécie de nova modéstia, pois o existir em espumas ou ser-nas-espumas diz de uma situação na qual as supervisões não são mais possíveis. As espumas são co-isoladas, vizinhas, mas inacessíveis umas às outras. Há multiplicidades espaciais e cada uma dessas multiplicidades constitui-se autorreferencialmente e não consegue assimilar a exterioridade do vizinho. Embora o vizinho esteja colado, ele está isolado e separado. E não há nada comum exceto uma "infiltração mimética de normas e estímulos e mercadorias contagiosas" (id., 2009a, p. 52).

Esferas III contém a analítica mais instigante e fecunda do que é estar-no-mundo na era do construtivismo agressivo e da explicação como ofensiva contra o oculto e a latência. O exemplo mais extremo desse construtivismo é a astronáutica tripulada. Fazer uma estação orbital não é colocar algo no meio ambiente, mas instalar o próprio ambiente no qual o existir e o "poder permanecer no mundo se torna plenamente dependente de doadores técnicos de mundo" (id., ibid., p. 246). É o caso de uma estação orbital como de máquina de imanência. Para que um astronauta respire e viva nessa máquina é necessário que a respiração, a água, o ar e os excrementos estejam inteiramente tematizados e esclarecidos. Se para produzir uma prótese de braço, o ente 
braço precisa estar dominado, do mesmo modo, a astronáutica mostra que o próprio mundo da vida pode ser protetizável. Assim, Espumas dá à pergunta "onde estamos quando estamos no mundo de hoje?" uma resposta contemporânea forte e consistente: estamos em "espaços humanamente habitados, simbolicamente climatizados" (id., ibid., p. 35) produzidos, e construídos de maneira artificial, a partir do desencadeamento dos processos de objetivação.

Sloterdijk não apenas reposiciona a filosofia mais recente, mas também, com sua abordagem imunológica, modifica tanto a maneira de fazer filosofia quanto a de contar sua história. Ele nos força também a desenvolver mandíbulas de sucuri para sermos capazes de abocanhar e digerir uma erudição e uma obra gigantesca, paradoxalmente tão clara, que prescindiria de comentário.

\section{2 Microesferologia e ontologia da intimidade}

Esferas I inicia-se com a descrição fenomenológica de dois aliados em uma comunidade insuflada: um menino na sacada brinca com as bolhas de sabão que sopra para o alto. Encantado, ele acompanha o trajeto da bolha e é como se o percurso dela, o seu manter-se no voo, dependesse da atenção extasiada dele. Fora de si e longe de sua base corporal, acompanha extaticamente a bolha, garantindo que ela não estoure prematuramente. A atenção do menino derramada e embebida na bolha a anima na mesma medida em que o voo sustentado da bolha o anima. Esse "ser-um-no-outro", esse dois em um, diz de uma relação específica em que crio alguma coisa na mesma medida em que sou criado pela coisa que crio. Esse tipo de relação paradoxal e surreal é impossível de ser descrita em termos do repertório da filosofia moderna. A gramática sujeito-objeto, herdeira da metafísica grega da substância, impede que se nomeie o espaço íntimo. Se nomeio o menino como "um sujeito cartesiano que permanece no seu ponto sem dimensão de pensamento enquanto observa um objeto [a bolha de sabão] com dimensão no seu caminho através do espaço" (id., 2003, p. 28), então eu teria ficado cego para o que se passa ali entre aqueles dois.

Ao lado da situação do menino e da bolha de sabão, Sloterdijk elege a relação entre Deus e Adão, tal como aparece na narrativa bíblica, como um segundo paradigma de relação íntima. Segundo esse relato, Deus aparece em um primeiro momento como 
um ceramista que produz um boneco oco. Apenas em um segundo tempo, revela-se que o oco, a natureza vascular de Adão, o constitui em canal para um inspirador. Deus sopra nas narinas de Adão e, do ponto de vista desse pacto pneumático, Deus também depende da animação do insuflado para se animar. Nas palavras de Sloterdijk, acerta quem percebe que "o chamado ser originário criador não é preexistente à obra pneumática, mas que se gera a si mesmo sincronicamente como íntimo-em-frente de seu igual" (id., ibid., p. 47). Trata-se de uma aliança ressoante, exercendo-se originariamente, e não há um primado ou uma antecedência ontológica de Deus.

Esses dois paradigmas de relação íntima (o menino e a bolha; Deus e Adão) bastam para notar que, para Sloterdijk, o primeiro, o mais elementar, aparece desde o início como dualidade correlativa; o início é consubjetivo, e não intersubjetivo conforme as fenomenologias predecentes. O originário é pensado sempre como teoria dos pares. A ontologia sloterdijkiana parte do dois e não do um. Sem esse dueto prévio dos mimos animadores não há ebulição nem nascença do um. Ninguém existe antes do seu animador. A natureza vascular (oca) do homem exige o soprador vivificante.

Para Sloterdijk, o ser humano é um canal oco e penetrável e, se ele não for visitado e preenchido por hóspedes duradouros, pode contrair um "catarro ontológico incurável” (id., 2007, p. 176) e não adquirir a dimensão da interioridade. O que chamamos de interioridade é o resultado de expropriações apropriadoras, mergulhos extáticos e gestos canibalizadores. Pensar a intimidade é pensar a área dessas ações e adentrar nesse tráfego de gestos incorporadores: a intimidade, essa imersão abissal no mais próximo, constitui uma região vedada a todos aqueles que permanecem reféns da linguagem sujeito/objeto. Paradoxalmente, a psicanálise freudiana, porque aprisionada nessa linguagem objetivante e ancorada numa "dogmática individualista e numa ontologia da coisa de base" (id., 2003, p. 420), não consegue nomear o espaço matriarcal e tem uma relação fóbica com o território vago e pastoso das misturas simbióticas. Uma das virtudes de Esferas I é que nele o ontologista do íntimo logra uma semântica adequada para adentrar nesses campos do início e consegue realizar uma síntese filosófica de vários achados clínicos pós-winicottianos. ${ }^{5}$ Se Heidegger já havia removido o entulho objetivante presente na psicanálise vienense sem, no entanto, plantar nada de positivo no terreno desconstruído, Sloterdijk, seu sucessor e

\footnotetext{
${ }^{5}$ Examinaremos a dívida pouco confessada de Sloterdijk com Winnicott no adendo II desta tese.
} 
complementador, encontrou a semântica adequada para adentrar o território misterioso da antropogênese.

Em uma representação possível, partir de sujeito e objeto equivale a partir de dois círculos inteiriços e consistentes. Começar dessa relação, entretanto, seria iniciar do "quilômetro quinze", pois um bebê humano não é ainda um sujeito dotado de psiquismo e capaz de se relacionar com objetos. A representação teria de ser a de um círculo dentro de outro e mostrar como só pouco a pouco o bebê emergirá como um ser separado a ter a consistência do círculo inteiriço. A linguagem sujeito/objeto falsifica o campo das dualidades arcaicas. Nesse, o dueto ressoante tem de tocar junto por muito tempo até que o repertório tenha entranhado numa das partes a ponto de ela conseguir tocar sua peça em outras circunstâncias e sem a presença do complementador. Só então, somente após muita "musculação" conjunta, o sujeito em devir poderia desempenhar sua parte sozinho em outros contextos. Sozinho aqui significa exatamente o contrário de solidão; o ter sido acompanhado, ter incorporado um repertório no encontro com o outro. A analítica sloterdijkiana é uma analítica do estar-acompanhado, enquanto a de Heidegger, existencialista no sentido problemático da palavra, é a da solidão.

Outra das virtudes de Esferas I é abrir os olhos do leitor para as várias legalidades esferológicas e suas semânticas específicas. Assim, se estamos no espaço inicial, onde o infante vai ser animado e dotado de alma, devemos falar apenas de nãoobjetos e pré-sujeitos. Nos duetos pré-objetivos e formativos - constitutivos da vida, o outro é o complementador íntimo e o gênio aliado, mas nunca um objeto. Objeto é aquilo cuja "deixabilidade" não afeta a consistência do sujeito. Já a perda do complementador íntimo é de outra natureza, pois ela é simultaneamente a perda do sujeito em vias de constituição. Essa mutação semântica concernente à discriminação da legalidade esferológica esclarece, por exemplo, uma questão como a da melancolia. Falar da perda do objeto no caso da melancolia é um exemplo de equívoco de legalidade esférica: o melancólico não é alguém que "perdeu um objeto", mas alguém de quem foi arrancado demasiadamente cedo o não-objeto complementador. Para Sloterdijk, o “desarranjo depressivo-melancólico é a resposta adequada do indivíduo, amputado do não-objeto, à atrofia do seu campo psíquico" (id., ibid., p. 422).

Se o um emerge do dois, e a própria interioridade humana é o precipitado de escavações e do mergulho de outros em mim, é mais apropriado não falar de indivíduo, mas de divíduos. O divíduo seria o mais originário e, nesse sentido, o ser humano não coincide com a unilateralidade do Dasein heideggeriano solitário e vazio de qualquer 
intimidade. Se a questão de Sloterdijk com Freud está ligada ao caráter objetificante da sua linguagem, com Heidegger, seu mestre decisivo e antecessor imediato, a questão fundamental da qual surgiu o próprio projeto Esferas tem a ver com o caráter abstrato da proposição do ser-no-mundo. De fato, Heidegger não consegue qualificar o ser-em (In-sein): o ser ou estar dentro do mundo. Ele pensa a irrupção originária na qual estamos suspensos dentro do nada, mas não o continente de pertencimento a partir do qual podemos dizer onde estamos quando estamos no mundo. Para Heidegger, e para muitos de seus seguidores no romantismo do aberto e do evento, é como se algo de essencial se perdesse quando nos localizamos mundanamente. Sloterdijk mostra de forma clara, contrariando a doxa propalada em manuais, teses e artigos, que Heidegger, embora tenha colocado seriamente a questão do ser-no-mundo e insistisse tanto no tema do enraizamento no mundo, nada sabia dos modos como esse enraizamento se realiza. A incitação filosófica de Heidegger aponta sempre para o ser-na-fronteira e para a experiência do acontecer original do mundo. Quer se tome Ser e tempo ou o pequeno opúsculo Que é metafísica? ou ainda outro texto, sempre leremos que é apenas quando a familiaridade escorre para o ralo e o ente emerge na estranheza, que se pode apreender a situação originária e o quem do Dasein. “[...] ser aí quer dizer: estar suspenso dentro do nada!” (HEIDEGGER, 1979, p. 41). Estar suspenso dentro do nada ou "estar entre (Das Zwischen) a essenciação do seer ${ }^{6}$ e a entitude do ente" (id., 2015, p. 17). Nada disso diz do estar no mundo calmo e sossegado. Para o pensador de Freiburg, o estar caído e apoiado no ente equivale a um estar-em-pecado ${ }^{7}$ e o homem que coincide com a sua determinação mundana é para Heidegger sempre alguém suspeito de não ter percebido que se encontra sequestrado. É apenas quando ele descoincide e difere da de terminação mundana que pode ganhar a si novamente.

Para Sloterdijk, não há motivos para desconfiar da determinação mundana, pois ela nasce criativamente no encontro com aliados íntimos. É nas relações fortes, completamente ausentes da analítica de Ser e tempo, e nas experiências de ressonância radical, nas quais o encontrado é uma criação minha, que simultaneamente me constitui e me cria, que emerge o repertório existencial e o si mesmo. É como no exemplo já

\footnotetext{
${ }^{6}$ Cf. sobre esta grafia a nota 91 , no capítulo 4 .

${ }^{7}$ Quem acompanhou a primeira onda da recepção heideggeriana no Brasil, formada pelos estudiosos Ernildo Stein, Emanuel Carneiro Leão e João Augusto A. Amazonas Macdowell, sabia disto, pois este último já mostrara em A gênese da ontologia fundamental de Martin Heidegger, sua dissertação defendida e publicada na Pontificia Universitas Gregoriana, Roma, em 1969, e editada no Brasil no ano seguinte, que os principais existenciais heideggerianos tinham protótipos cristãos e eram resultantes de laicizações da teologia.
} 
dado no convívio do menino com sua bolha de sabão. Se ele ali adquire consistência e se expande é exatamente porque a bolha de sabão é uma criação sua e não uma exterioridade qualquer. Se usasse a linguagem objetal da psicanálise, dir-se-ia que a bolha de sabão é um objeto-eu-mesmo, um (ob)je, em francês, e é apenas no mimo desse espaço de ressonâncias onde o menino é um mago-criador que ele adquire a musculatura vertebrada do si mesmo e escapa do vazio invertebrado da desterritorialização. Se o si mesmo cresce no calor da amizade e do encontro, não há razão para que esse si-mesmo (Selbst) não coincida consigo próprio ou para se supor que ele está alienado. Não há também porque desfazer ou desconstruir o que surgiu a partir da incorporação produtiva daquilo que se ofereceu à altura do gesto canibalizante.

O Ser e tempo de Heidegger desconhece a esfera íntima e a dimensão do acompanhamento. Ao encabeçar a xenofilia das ontologias contemporâneas, Heidegger e a grande maioria dos filósofos do século recém-encerrado não poderiam descrever ou soletrar o que acontece no jogo do menino e da bolha de sabão, esse belo jogo demiúrgico no qual o mundo é criado. Estariam cegos para acontecimentos decisivos. As análises de Ser e tempo sobre o ser-com cotidiano, olhadas retrospectivamente à luz de Esferas I, espantam pela insuficiência. Não há irmãos juramentados, casais apaixonados e muito menos bebês mamando nos peitos de mães. Na analítica heideggeriana, encontramos sapateiros, marceneiros e leiteiros, mas nunca uma mãe ou uma namorada. Os outros, para Heidegger, vêm ao encontro "a partir do mundo em que o Dasein se mantém, de modo essencial, empenhado em ocupações guiadas por uma circunvisão" (HEIDEGGER, Ser e tempo, \$26, 2006, p. 175). Vale dizer que é o caráter utensiliar da mundanidade do mundo que dá o tom à analítica do com, quando, na verdade, a operação está invertida, pois é apenas a partir de um certo tipo de estar-com (o ser-um-no-outro) e da estada na estufa imunológica que posso adentrar o mundo e nele me enraizar. É na discussão do enraizamento no mundo que Sloterdijk se autocompreende como um continuador e um crítico de Heidegger:

somos da opinião de que pela teoria dos pares, dos gênios e da existência complementada se faz justiça ao interesse de Heidegger pelo enraizamento, e este é recuperado tanto quanto é possível (SLOTERDIJK, 2003, p. 312).

$\mathrm{O}$ enraizamento no mundo é assunto inter-humano. O pensamento da diferença ontológica ao se deter no rasgo da eventualização do ser no ente não tem repertório 
suficiente para pensar a diferença entre o estar exposto, o estar no puro exterior e o estar ocupando um espaço interior. Essa é para Sloterdijk a diferença fundamental. Para pensar o adentramento no espaço interior, é preciso entender de aliados, acompanhantes e ressonâncias. $\mathrm{O}$ exterior e a perplexidade seriam nosso endereço permanente, e o enigma, nossa única matriz se o ente jamais chegasse até nós convidativamente e numa área de hospitalidade. É uma área de hospitalidade aquela em que o "bilu-bilu" dito pelo anfitrião complementador realmente nos convence de que aquilo que tomamos para nós, longe de ser uma mera coisa diante dos olhos ou um utensílio é uma criatura nossa viva e pulsante. $\mathrm{O}$ abraço do aliado delimita a fronteira de um ovo, um envoltório protetivo no interior do qual aquilo que vem ao encontro adquire uma feição familiar e uma digital humana. Se estamos Dentro, já não estamos soltos ao "pé das coisas e ao pé das pessoas" (id., 2008a, p. 164). A delimitação do abraço opera uma transfiguração, pois o que surge nesse espaço, longe de ser uma simples coisa no jorro estranho de uma fulguração alética, passa a ser, na medida em que nomeados e tocados pelo aliado, uma coisa-amiga, uma entidade-benigna, que se derrama sobre mim, me povoando e me retirando lá de Fora. Ser resgatado da exterioridade é experimentar alguma coisa como um demônio benigno que me possui e me toma no mesmo momento em que eu a tomo como é o caso do leite materno. Sloterdijk diz que se a dose de leite materno fosse um sujeito e não um ente, se fosse um demônio benigno, se poderia dizer sem exagero que ele toma posse do seu consumidor e se instala como um ocupante que pensa ficar por longo prazo.

Sem dúvida este seria um método correto de derivar a animação do infans do seu trato com demônios. Receber uma alma não significaria então outra coisa que cair sob uma obsessão benigna graças ao contacto com espíritos e a uma incorporação produtiva. (id., 2003, p. 95)

Adentrar no mundo não coincide, portanto, com o nascimento biológico, mas tem que ver com a participação em relações de proximidade no interior de receptáculos autogerados, que paradoxalmente contêm a si mesmos. Nesse sentido, "um par 'consistente' é um contentor autógeno deste tipo, um autorreceptáculo" (id., 2007, p. 119). Se um "par consistente" é uma espacialidade, há de se descrever fenomenologicamente esse espaço a fim de realmente compreendermos "onde estamos quando estamos no mundo". Estamos na própria casa ou no aeroporto? Estamos no interior da placenta, no berço ou em uma reunião de executivos da era globalizada? 
Mais importante: chegamos a ter alguma feição ou ficamos desenraizados sem saber quem somos e quem são os outros? A principal deficiência da analítica heideggeriana de Ser e tempo diz respeito à questão da espacialidade existencial. Heidegger faz anúncios e assina promissórias que não pagará. Para Sloterdijk, Heidegger acerta ao falar negativamente e mostrar que não estamos no mundo feito bonecas russas (o que equivale a destituir o reino plurimilenário da metafísica e da física dos receptáculos), mas ele decepciona o seu leitor quando tenta explicitar positivamente o estar-no-mundo no sentido do poder-estar-em-casa e do habitar. A semântica existencial heideggeriana é deficitária quando trata de dar conta da familiaridade e das suas matrizes. Se as análises heideggerianas da filosofia cartesiana também apontam para o esquecimento do ser-em e do ser-no-mundo no pensamento moderno, quando Heidegger, por sua vez, formula seus próprios enunciados positivos sobre a espacialidade do Dasein, não temos mais do que poucas páginas ou mesmo alguns parágrafos sobre o desdistanciamento (Entfernung) e a direção (Ausrichtung). Para Sloterdijk, a sinfonia prometida nos acordes da abertura fica interrompida, e o leitor sente-se fraudado. É precisamente para preencher esse déficit que a palavra Esferas toma a cena.

Pode-se, portanto, formular sinteticamente que se Heidegger pensa o movimento e o salto mundo adentro, evocando "o modo de ser de uma entidade que na mesma medida em que está no mundo, está no salto para o mundo" (id., 2008a, p. 90-91), o exreitor de Karlsruhe, menos refratário aos caseiros e aos amigados, logra pensar o instalar-se em um Interior. É essa relação positiva com o instalar-se que transparece no termo-guia Esferas. Não se trata apenas de que é difícil existir suspenso num salto sem apoio, mas de constatar que Heidegger não consegue pensar a aterrissagem a não ser como uma perda e uma narcotização. Para pensar a aterrissagem ou o mergulho para o interior, a analítica heideggeriana não poderia compreender o ser-aí a partir de "um suposto impulso essencial para a solidão" (id., 2003, p. 311). "A analítica do onde existencial exige que se coloque entre parênteses todas as sugestões e estados de ânimo de solidão essencial, para assenhorar-se das estruturas profundas do ser-aí acompanhado e complementado" (id., ibid.). Para Sloterdijk, no que diz respeito a este tipo de tarefa,

o primeiro Heidegger segue sendo, no sentido problemático da expressão, um existencialista. $\mathrm{O}$ rápido deslocamento de Heidegger para a pergunta pelo quem deixa atrás um sujeito existencial solitário, débil, histérico-heroico, que pensa ser o primeiro a morrer e vive na incerteza, queixando-se a respeito dos traços mais escondidos de sua inclusão em intimidades e solidariedades (id., ibid.). 
O interessante nessas passagens é que Sloterdijk não está falando de opções teóricas abstratas, mas do umbigo do pensador Heidegger e das consequências políticas da sua incapacidade de enxergar micro e macroesferologicamente. Um homem desenraizado sonha intimizar-se com o povo mais próximo da mesma maneira que um menino desencontrado da periferia sonha tornar-se um líder de torcida organizada ou de alguma gangue. São nos movimentos de mergulho e de absorção que o sujeito busca ilusoriamente uma participação. Para Sloterdijk, "quem cai na força de absorção do torvelinho, embora pareça estar aqui, vive em outra esfera, em um cenário longínquo, em um aí interior não compreendido" (id., ibid., p. 312).

Se Heidegger reprovava na fenomenologia husserliana o fato de ela ser cega tanto para o ser dos instrumentos quanto para o ser-para-a-morte, Sloterdijk mostra que Heidegger é cego para os fenômenos esferológicos. A esfera certamente não é algo constatável empiricamente, mas ela está presente, ao seu modo, sempre que nos deparamos com seres humanos. Trata-se apenas de conquistar o olhar para esse realissimum e para o mais notório que é o arredondamento espontâneo que acontece entre seres humanos. ${ }^{8}$ A cegueira heideggeriana para o fenômeno esferológico impediuo não só de pensar a estabilidade do habitar (que não tem nada a ver com a inquietante extimidade da habitação no Heidegger tardio), mas também o impediu de esclarecer a diferença entre o "onde" da política e o "onde" matricial do ponto de partida. Para Sloterdijk, a obra tardia de Heidegger vive da ressaca do revolucionário frustrado após a tentativa de aterrissagem no colo do povo mais próximo. Desfeito o delírio de grande líder de movimento, Heidegger retira-se dos empreendimentos políticos e

busca sua salvação em exercícios de proximidade ainda mais íntimos. Aposta tenazmente na sua província anárquica e organiza visitas à casa do ser e da linguagem guiadas por conselheiros completamente mágicos, providos de chaves pesadas e sempre dispostos a advertências significativas (id., ibid.).

Para Sloterdijk, Heidegger jamais voltou ao ponto que precisaria ter voltado, a saber, o de recolocar a pergunta pela disposição originária do mundo. Se o filósofo de

\footnotetext{
${ }^{8}$ A espacialidade interior animada é um redondo não geométrico, conforme as palavras de Bachelard na epígrafe de Esferas I: "A dificuldade que tivemos de vencer ao escrever este capítulo foi a de afastar-nos de toda evidência geométrica. Noutras palavras, tivemos de partir de uma espécie de intimidade do redondo" (BACHELARD, 2012, p. 22).
} 
Karlsruhe se encaminhou na direção de pensar o ser humano como um tipo de migrante que chega prematuramente do interior materno e que depende, por isso, de mecenatos biológicos e mimos de seres que emprestem seus próprios corpos para que esses, como pequenas arcas e escudos íntimos, controlem inclusive o quantum, o volume de mundo que pode entrar no interior da célula de intimidade, o pensador de Freiburg fincou estaca na exterioridade e no clarão inquietante da experiência do acontecimento do ser. Como Sloterdijk dirá na entrevista concedida a Hans Jürgen Heinrichs e publicada em livro com o título $O$ sol e a morte, Heidegger fundou uma religião da clareira e para essa religião o mais decisivo é que os homens já não decidam nada a não ser a "meditar sobre esse clarão luminoso e aprender a temerem-se à luz desse clarão como Unheimliche, estranhos inquietantes" (id., 2007, p. 94).

Se o retiro de Heidegger e seu finca-pé na afeição pela inicialidade nua faz dele um mestre religioso comparável a Lao-Tsé ou Nargajuna, Sloterdijk, pensador dos trânsitos e passagens, é alguém que pode pensar a política. Só pode ter repertório e competência para pensar a política aquele que é capaz de compreender as migrações do pequeno ao grande e o transporte ou "transferência" de familiaridade e confiança desde os pequenos espaços até as estruturas macrossociais. Se os humanos são seres da familiaridade - e o são efetivamente! -, o pensamento de Heidegger será sempre minoritário e jamais fará época. ${ }^{9}$

Como escreveu Hannah Arendt na sua famosa apologia comemorativa do aniversário de oitenta anos de Heidegger, há sempre um poder de se espantar diante do simples, mas algo bem diferente disso é "aceitar esse espanto como morada" (ARENDT, 1987, p. 231). Sloterdijk, reconhecidamente um continuador em muitos aspectos das reflexões de Arendt, apesar de também criticá-la, diria que é impossível residir no espanto. Já uma simples casa humana é precisamente, como mostra Esferas III, uma máquina de rotinas e hábitos. Para morar no espanto seria necessária a paradoxal acomodação mística na catástrofe esferológica, o que é assunto para minorias religiosas e seitas poéticas. Ao invés do delírio, segundo o qual o pastor do ser possa inaugurar uma nova clareira epocal com o seu chamado (que, na verdade, não é seu, mas do próprio ser) para fora do regime metafísico de experiência, seria mais sensato inverter sloterdijkianamente a questão e saber como conseguem sobreviver e ganhar

\footnotetext{
9 Como escreve ironicamente Sloterdijk, o pensar heideggeriano é ótimo para uma "época pósmissionária, pós-científica, pós-universalista e pós-voluntarista. Mas uma época assim não existe" (SLOTERDIJK, 2011, p. 38).
} 
alguma proteção os poucos pastores do ser que vivem no interior do construtivismo agressivo da modernidade. Quanto de herança ou de renda eles teriam que ter? Como organizar uma proteção jurídica para os pastores legítimos? E quem faria o RH palaciano dos candidatos a pastor do ser?

A ideia nutrida por Heidegger em Beiträge, de que haverá um dia uma época alética, um novo (outro) começo no qual o estremecer do Dasein reesquentasse a história sob a figura do evento, é uma ideia religiosa reveladora de ignorância em matéria antropológica. Sloterdijk considera não só que não haverá algo como uma superação da metafísica e da técnica, mas também a lucidez no trato dos assuntos humanos nos obriga a reconhecer que o homem é, antes de tudo, um animal familiar, e a questão decisiva é compreender os processos de transmissão da confiança dos mundos pequenos para os grandes. Para um culturólogo e pensador político, tanto a questão do além-homem nietzscheano $^{10}$ quanto a da quebra do sentido possibilitadora do habitar à luz do desamparo são questões extremamente minoritárias e mais aparentadas com o heroísmo romântico das vanguardas artísticas do século XX do que com a maioria dos homens, que vive assentada no sentido e na continuidade sustentadora de descontinuidades. $\mathrm{O}$ enaltecimento unilateral da descontinuidade pelas filosofias da diferença também mostra ignorância quanto à importância da continuidade para o ser humano.

O fenômeno da catástrofe esferológica e do estresse espacial na microesfera, segundo Sloterdijk, conduz mais a figuras da psicose do que a figuras do pensamento. Quando o "ponto de partida para transferências positivas e criativas [...] já está comprometido, as simbioses estão contaminadas, os espaços familiares de proteção e o biótopo da familiaridade estão atrofiados" (SLOTERDIJK, 2007, p. 152), surgem os "desequilíbrios de filiação" nos quais o indivíduo desenraizado já não tem noção de quem ele é e do que leva ou não leva para o mundo. Se um menino brincou com o seu pai e seus olhos brilharam ao jogar futebol, e esse pai, então, presenteou esse menino com várias bolas de futebol cada vez mais bonitas em aniversários e sucessivos natais, e o menino se alegrou e voltou a se alegrar, pois o jogo com a bola não era uma imposição paterna, mas um gesto brotado no corpo desse menino, então quando o menino em questão (a propósito, um menino não em questão) chegar ao mundo escolar,

\footnotetext{
${ }^{10}$ Nietzsche "contrapôs o ideal socialdemocrata da satisfação universal de necessidades humanas básicas à autoelevação dos poucos que são criativos em sua obra, e que vivem sob tensões grandes e máximas, embora a sociedade à sua volta há muito tenha decretado a palavra de ordem 'deixe estar'. Faz tempo que não é mais possível termos dúvida do caráter minoritário e cultural e politicamente sem perspectivas dessa opção" (SLOTERDIJK, 2002b, p. 70).
} 
oriundo do mundo familiar, poderá dizer que gosta de futebol e o professor de educação física o reconhecerá como um jogador, e o menino, provavelmente, durante o período da educação infantil chamará este professor de tio. ${ }^{11}$ Todavia, quando o espaço familiar está atrofiado e a estufa implodiu, o menino passa despercebido ${ }^{12}$ e, fora de qualquer relação, tentará se constituir com heróis virtuais ou figuras de desenho animado. Assim parece ter sido o caso do jovem tornado famoso pela mídia brasileira, morto recentemente de câncer em Uberlândia, que havia se convertido no boneco Ken, namorado da Barbie. Como esse exemplo, os psicanalistas atuais contam de vários outros jovens pacientes que, por meio de cirurgias plásticas continuadas, procuram desenhar-se e constituir-se a partir de heróis e personagens virtuais. Foram meninos desse tipo que, nascidos há cerca de cem anos, no início do século $\mathrm{XX}$, se agruparam “atrás desse vulgar anjo da morte que foi Hitler" (id., ibid., p. 153). É nesse sentido que a esferologia e a analítica microesferológica revelam todo o seu potencial de análise política e permitem compreender a gênese dos indivíduos fascistas ou "com pendor para atitudes de extrema direita" (id., ibid.) mais profundamente do que os filósofos, como aqueles da última geração da escola de Frankfurt, que trabalham com a categoria hegeliana do reconhecimento. ${ }^{13}$

Vimos até agora que Sloterdijk se esforça para liberar-se do "fetichismo da substância" e do "individualismo metafísico" na análise das relações humanas. Sua teoria acerca das dualidades arcaicas pretende colocar em questão a blindagem individualista bem como o primado da ocularidade e da imagem decorrentes da gramática sujeito/objeto. Para escapar desse repertório habitual, Sloterdijk recorre à noção de não-objeto de Thomas Macho ${ }^{14}$ e tenta conceber as dualidades iniciais menos oticamente e mais como duetos musicais, uma vez que as experiências acústicas não se deixam descrever em termos de relações objetais com algo situado em frente, mas em

11 Chamar ou não um professor de "tio" é uma discussão esferológica. Paulo Freire, em seu livro Professora, sim; tia, não: cartas a quem ousa ensinar (2013), por exemplo, defende que o educador profissional, por não pertencer ao ambiente familiar, não pode ser chamado assim. Para ele, a escola situa-se já em outro regime de legalidade esferológica.

12 Trabalhei o tema do "menino em questão" e da catástrofe esferológica na heterotanatografia "Esse menino aí, em Testemunho transiente (PESSANHA, 2015, p. 161-185).

${ }^{13}$ É o caso de Axel Honneth em Luta por reconhecimento: a gramática moral dos conflitos sociais. Stoterdijk não se utiliza dessa noção em suas análises do universo microesférico. Microesferolegicamente falando, de nada adiantaria um reconhecimento sem acompanhamento e ressonância. Foi Lacan quem introduziu a categoria hegeliana de reconhecimento na psicanálise por meio de Kojève. Sloterdijk considera que a introdução deste elemento timótico (de Thymós) da luta pelo reconhecimento, no interior da erótica psicanalítica, faz implodir o "edifício doutrinário freudiano" (SLOTERDIJK, 2012b, p. 30).

14 Thomas Macho é filósofo da cultura e antropólogo dos meios. É um dos autores contemporâneos mais citados por Sloterdijk ao lado de alguns outros como: Dieter Claessens, Gotthard Günther e Heiner Mühlmann. 
termos de ser-introduzido-na covibração musical. Com esse deslocamento, a esferologia pode afirmar que "toda animação é um acontecimento medial e que todo transtorno anímico é uma distorção da participação, enfermidade medial” (id., 2003, p. 277). Isso quer dizer que se os duetos iniciais vibraram apaixonadamente em mútua devoção, no momento da quebra esferológica e do migrar desenraizador para novos mundos estranhos, não mais arredondados pela presença do aliado, o indivíduo pode seguir e ir para diante exatamente porque está carregado e dotado de recordações capazes de, como um pequeno Midas, integrar e amansar a exterioridade. Para a esferologia, o divíduo pode agora "perder" a mãe e seguir para mundos maiores, porque ela ou o aliado-chave já foi incorporado e faz parte dele. Entende-se aqui a crítica do pensamento esferológico à "antropologia trágica idiossincrática”, que é o pensamento de Jacques Lacan, na medida em que proclama a perda da mãe como um destino geral para o ser humano. Segundo o pensamento esferológico, são apenas alguns "azarados", mas não todos os seres humanos, os que ficaram desatendidos e amputados da mãe. Se esses poucos bebês abandonados e tomados por terríveis tensões de aniquilamento sentem-se reconfortados pela completude da autoimagem no espelho, a grande maioria dos bebês humanos não encontra nada demais na imagem especular ou pelo menos nada que já não estivesse delineado nele "há muito tempo no nível dos jogos de ressonância vocais, táteis, interfaciais e emocionais e seus sedimentos internos” (id., ibid., p. 480). Um menino não abandonado " "sabe' muito bem e muito exatamente o que significa ser uma vida invulnerável no interior de um dueto continente suportador" (id., ibid.), e ele não precisa da própria imagem para saber disso. Aquele que encontrou mamilos eudaimônicos e fadas bebíveis a velar seu berço e que foi escavado por invasões proveitosas (id., ibid., p. 97) não depende de certezas imaginárias e eidéticas para sustentar sua integridade. A certeza pré-imaginária do poder ser-integro emana da gruta de amor e do clube de associados que habitam o menino como o precipitado resultante da ressonância entre bons aliados. Para Sloterdijk, todo o drama humano é que nem sempre o aliado é bom ou atento e se

o jogo de ressonâncias entre o menino e o seu em-frente complementador estiver viciado por ambivalências, desatenções, sadismos naturalmente se abrirá a possibilidade no menino para uma inclinação a se ater aos breves momentos de experiência positiva de complementação: sejam amabilidades precárias das pessoas com as quais se relaciona, sejam sonhos autoeróticos de retirada ou desdobramento sobre si mesmo, sejam identificações com os heróis invulneráveis de contos e mitos (id., ibid., p. 481). 
Pode até mesmo acontecer que algum menino psicótico fuja do monstro que ele pressente sob a pele despedaçada para a ilusão figurativa de inteireza, que reina na imagem, mas isso é apenas um caso particular possível e jamais um teorema universal. Sloterdijk considera que Lacan universaliza a situação desse menino e transforma a instabilidade paranoica, que é uma característica da conformação do eu no imaginário, em algo central. Para alguém cuja inteireza depende da imagem, apenas a sujeição à "lei simbólica libera de uma psicose constitutiva" (id., ibid., p. 482). Sloterdijk acredita que Lacan se entregou ao dogmatismo da protopsicose e isso porque ele estava comprometido "com interesses não psicanalíticos, mas criptocatólicos, surrealistas e para-fílosóficos" (id., ibid.).

Se a crítica da esferologia à psicanálise vienense era fácil de ser adivinhada, uma vez que os trabalhos de Freud ${ }^{15}$ estão marcados pela tendência objetivante, no que diz respeito a Lacan - que no curso A ética na psicanálise cunhou a expressão "a coisa" (la chose) para nomear um objeto psicológico pré-objetivo -, a crítica incide na ideia de que a perda da mãe apareça como um destino geral humano.

As geniais explicações de Lacan sobre la chose - em cujo conceito ressoa toda uma série de tons concomitantes, que vai desde o conceito de Deus do Mestre Eckhart até a coisa em si de Kant - estão repletas de ambiguidades insolúveis, de modo que fica impossível discriminar com clareza o que é que aproxima de uma análise das comunhões não objetivas e o que é que se avizinha da edificante, psicanalítica e psicohigienicamente renovada doutrina paulina da proibição possibilitadora de desejo. Mas segue sendo inaceitável o abuso com o qual o reforço de Lacan da proibição do incesto, em cuja exposição salta aos olhos seu catolicismo, se transforma em uma antropologia trágica idiossincrática. (id., ibid., p. 423)

A afirmação de que todos somos órfãos de la chose implica, para Sloterdijk, um nivelamento dos males neuróticos e psicóticos. Se a solidão começa mesmo no berço e ela é inevitável e universal, então não há porque oferecer ajuda em catástrofes psíquicas. Melhor fundar uma schola filosófica para seres fortes e acostumados com a solidão uma escola de tipo neoantigo -, ou fazer parte de uma equipe de heideggerianos nadificados. Pode-se dizer resumidamente que, para Sloterdijk, o desejo de Lacan de aliar-se às rupturas do vanguardismo estético empobreceu sua psicanálise: a ideia de que

\footnotetext{
${ }^{15}$ A crítica mais forte ao espírito do pensamento freudiano encontra-se em Ira e tempo, obra na qual Sloterdijk afirma que Narciso e Édipo jamais poderiam ser tomados como "emblema da conditio humana" (SLOTERDIJK, 2012b, p. 27).
} 
o "eu" é lugar de alienação e que, portanto, a cura implicaria uma dissolução do "eu" algo muito próximo de Bataille e Blanchot, por exemplo - é algo que pode transformar alguém em amigo de Salvador Dalí, mas, certamente, não traz muito para quem busca ajuda terapêutica, porque já se encontra despersonalizado e vivendo ansiedades psicóticas.

Sloterdijk considera que a psicanálise é excessivamente ótica e orientada pelas noções de imago, objeto e espelho. Essas noções nada dizem do mundo primário, pois neste não há espelhos, mas jogos de ressonância e ecos afetivos. No mundo primário, não se pode falar de objetos e de relações subjetivas/objetivas, uma vez que tanto no interior pré-natal quanto no começo do mundo do recém-nascido os "sujeitos reais [...] sangue, líquido amniótico, vozes, tenda de sons e ar para respirar - são meios de um universo pré-ótico" (id., ibid., p. 295). Quanto aos espelhos, foi só muito tardiamente, nos séculos XIX e XX, que eles saturaram os lares. Durante milênios, não havia autocomplementação possível, e os seres humanos não se viam a si mesmos. Sem este instrumento egotécnico de autocomplementação, ${ }^{16}$ os teoremas pseudoevidentes de Freud e seus sucessores "sobre o chamado narcisismo e sobre o suposto autoerotismo primário, oticamente mediado" (id., ibid., p. 182), não teriam se tornado populares.

No estado inicial microesférico, há uma integração bipolar e ela nada tem a ver com a discreta reflexão especular de superfícies vítreas. Na unicidade dupla do espaço mãe-filho não há também que soletrar a gramática psicanalítica do objeto. Quando o ser-aí humano encontra-se na coabitação fetal, as "coisas" que o circundam - líquidoamniótico, cordão e membrana umbilical etc. - não têm o modo confrontador do objeto. O primeiro lugar é o aí placentário e ele funciona como nutridor e acompanhante. A placenta não tem o modo do "em frente" e tampouco o feto é já um "em frente" (ele é ainda um pré-sujeito). Nesse aí inicial, concretamente qualificado, ${ }^{17}$ o feto flutua e recebe o sangue placentário e, para descrever esta flutuação comum no meio fluido, é necessário aprender a linguagem dos não-objetos. Sloterdijk considera que uma linguagem teórica medial deve substituir as descrições feitas em termos de relações objetais. O sangue, nesse sentido, é o primeiro "médium material entre dois indivíduos"

\footnotetext{
${ }^{16}$ Esferas III desenvolverá uma teoria do individualismo e do estar só complementado e amparado por meios. O espelho é apenas o começo de um regime no qual progressivamente se substituem os complementadores humanos por meios egotécnicos e aparelhos de autocomplementariedade. Quando esse regime predomina, estamos numa "sociedade" moderna.

${ }^{17}$ As passagens de Esferas I referentes à placenta esclarecem bem o empreendimento sloterdijkiano de uma analítica do espaço radicalmente concreta e antiespeculativa. Parte do aí no espaço intrauterino até o estar nas espumas do homem contemporâneo no mundo globalizado.
} 
(id., ibid., p. 274). Também os acontecimentos sonoros no interior da mãe só se dão como não-objetos uma vez que

as presenças sonoras não têm substrato coisal [...]. A fisiologia do ouvir como ser-introduzido-em-covibração torna evidente que no caso das experiências acústicas se trata de fenômenos mediais que é impossível representar em linguagens de relação de objeto (id., ibid., p. 275).

Escutar é estar possuído pelo som. A teoria medial da intimidade deve muito às investigações de Alfred Tomatis e Thomas Macho no campo da pré-natalidade. Embora Sloterdijk seja crítico do "idealismo matriarcalista do sistema de Tomatis" (id., 2004a, p. 188), esses dois autores ajudam a compreender a limitação dos conceitos fundamentais da psicanálise. Se esta última não encontrar uma linguagem mais apropriada para falar da proximidade humana, o aprisionamento no idioma filosófico do objeto faz da própria prática psicanalítica um "sistema de defesa contra as experiências de proximidade" (id., 2003, p. 271). O ser humano não começa sua vida num panóptico de objetos parciais e imagens, mas participando em circunstâncias mediais de animação. Já o líquido amniótico transmite ondas sonoras através dos ossos do feto e quanto às experiências do recém-nascido, foco da atenção do antropólogo dos meios, Thomas Macho, o uso da voz no meio aéreo "assegura a conexão com a mãe fora da cavidade corporal" (id., ibid., p. 275). A troca de sons entre mãe e filho, a escuta mútua da díade equivale a um cordão umbilical acústico. A esfera bipolar inicial é acústica e não tem caráter objetal. O mesmo deve ser dito do ar respirado: ele é uma magnitude medial que não tem qualidade objetiva.

Como se manifesta já na primeira experiência, o ar possui qualidades não objetivas inequívocas já que proporciona ao sujeito em devir uma primeira possibilidade de autoatividade em autonomia respiratória sem aparecer jamais [...] como uma coisa ou objeto com o qual pudesse entabular-se uma relação. (id., ibid., p. 276-277)

O complexo fundamental ar-respiração-eu também aponta para a indigência do léxico psicanalítico. Espera-se que novos pensadores esferológicos atentos aos acontecimentos mediais de animação possam contribuir e alargar a semântica póskantiana da psicanálise que prende até psicanalistas considerados inventivos. 


\section{ADENDO I}

\section{Sobre a diferença entre estar exposto e estar incluído}

Neste breve acréscimo, pretende-se esclarecer a diferença antropológica fundamental, a saber, a diferença sloterdijkiana entre estar exposto e estar incluído. No aforismo intitulado "Passageiro", Kafka escreve:

Estou em pé na plataforma do bonde elétrico e totalmente inseguro em relação à minha posição neste mundo, nesta cidade, na minha família. Nem de passagem eu seria capaz de apontar as reivindicações que poderia fazer, com direito, na direção que fosse. Não posso de modo algum sustentar que estou nesta plataforma, que me seguro nesta alça, que me deixo transportar por este bonde, que as pessoas se desviam dele ou andam calmamente ou param diante das vitrines. É claro que ninguém exige isso de mim, mas dá no mesmo.

$\mathrm{O}$ bonde se aproxima de uma parada, uma jovem se coloca perto dos degraus pronta para descer. Aparece tão nítida para mim que é como se eu a tivesse apalpado. Está vestida de preto, as pregas da saia quase não se movem, a blusa é justa e tem uma gola de renda branca fina, ela mantém a mão esquerda espalmada na parede do bonde e a sombrinha da mão direita se apoia no penúltimo degrau mais alto. Seu rosto é moreno, o nariz levemente amassado dos lados termina redondo e largo. Ela tem cabelos castanhos fartos e pelinhos esvoaçando na têmpora direita. Sua orelha pequena é bem ajustada, mas por estar próximo eu vejo toda a parte de trás da concha direita e a sombra da base.

Naquela ocasião eu me perguntei: como é que ela não está espantada consigo mesma, conserva a boca fechada e não diz coisas desse tipo? (KAFKA, 1991, p. 37-38)

Esse fragmento kafkiano é interessante como documento sobre o não estar incluído e a exterioridade. O narrador em primeira pessoa diz da condição desassossegada de quem não tem lugar e nem familiaridade com o mundo. É como se alguém que ao começar a redigir algumas linhas visse o sentido das palavras desaparecer e sua materialidade crescesse com a brancura do papel, até que a pessoa em questão já não soubesse mais situar-se em relação à tarefa que estava realizando. Uma experiência desse tipo é aquela descrita por Heidegger como a da visita da angústia. Na visita da angústia, a familiaridade do sentido se esvai e o ente emerge na estranheza. $O$ filósofo de Freiburg dignificou essa posição e deu a ela uma cidadania filosófica na mesma medida em que mostrou que nascia aí uma outra relação com a linguagem. Na sua esteira, pensadores como Blanchot se detiveram nesse espaço do desastre. Um 
espaço de pura exterioridade onde está ausente qualquer intimidade. Para Blanchot, aí nesse lugar, de onde Kafka diz, já não é o "eu” que fala e se exprime, mas o ser: "Aí onde ele está, só fala o ser - o que significa que a palavra já não fala mais, mas é, mas consagra-se à pura passividade do ser" (BLANCHOT, 1988, p. 21). Esse lugar é um outro de qualquer mundo e o poeta é aí conduzido pela exigência da obra. A exigência da obra arranca o escritor do mundo e o coloca fora, num lugar exterior e distante daquele onde vigora a digital e a pertença ao sentido (província da cultura).

Para a esferologia sloterdijkiana, entretanto, a superação da posição antropológica pela visita do ser ou pela exigência da obra depende da catástrofe e do desencontro antropológicos: "Man's calamities are Being’s oportunity" (SLOTERDIJK, 2011, p. 28). Sloterdijk considera que não há superação da posição antropológica, mas apenas diferença antropológica, e a diferença importante é aquela entre o residir no partilhado e a catástrofe esferológica, ${ }^{18}$ afinal, quem é o habitante desta região "onde a impossibilidade já não é privação, mas afirmação"? (BLANCHOT, 1988, p. 296). Quem é o rapaz do bonde, o perplexo com a janela escancarada? Ali onde o porta-voz da exterioridade diz de uma insegurança radical de sua posição neste mundo e de um não saber qual reivindicação fazer, a moça do bonde cuja presença é motivo de uma indagação sem fim por parte do rapaz, poderia dizer que está tranquila, ruminando a última conversa com seu noivo e algumas exigências que faria no trabalho. Se o rapaz está desprovido de mundo e de interioridade é porque seu gesto primeiro foi vomitar e recusar o leite materno. Seu gesto foi um gesto-não! ${ }^{19}$ Já para ilustrar com a moça a posição incluída, a posição de quem se "instalou buscando segurança, como mansa habitante da normalidade e como inquilina de seus centros de tranquilidade e sossego" (SLOTERDIJK, 2003, p. 92), pode-se afirmar que ela teria interioridade e localização porque, quando bebê, ao tomar o leite tivera o corpo tomado por ele e incluíra-se no interior de um outro que lhe ofertara lugar, tendo podido assim ganhar território e "uma certa comodidade distendida" (id., ibid.). Desse modo, enquanto o rapaz na falta de teto e de chão, na falta dessa imersão na ambiência do outro, se pergunta o que se passa com a moça e como é que ela não está espantada consigo mesma, a moça, incluída "extaticamente com outros [...] no comum habitat do mundo" (id., ibid., p. 86), se

\footnotetext{
18 "Só nas catástrofes, quando todos os habitats explodem e se torna patente a nudez do exterior é que os mortais talvez possam ser 'contidos no nada', como diz Heidegger, mas, regra geral, o que se lhes aplica é a lei da residência no espaço partilhado, o princípio de que as esferas formam a sua própria espessura" (SLOTERDIJK, 2007, p. 119).

${ }_{19}$ Veremos, no adendo II, como a psicanálise winnicottiana traça a gênese da profundidade e da interioridade humana.
} 
perguntaria por que aquele rapaz que tanto olha para ela não está sossegado e por que é que está assim tão espantado e com a janela escancarada?

Ao se tomar o fragmento kafkiano como um informe sobre o não estar incluído e a exterioridade, surpreende que essa posição extrema tenha se tornado quase paradigmática na filosofia francesa do pós-guerra. Este exemplo seria dignificado por Deleuze como o de um desterritorializado sem órgãos; o de alguém que corre por uma linha de fuga numa movimentação anômala, que difere de qualquer determinação identitária. Já para Lacan, o mesmo fragmento tornaria claro o que é estar fora da posição subjetiva e desconhecer a consistência ilusória do eu (Moi): é a posição de um dizente "fala-ser", pois, tocado pela extimidade e exposto ao abismo, diz sem a gordura do sentido. É alguém "no limiar do silêncio e da letra”, conforme o título de um livro de Maria Lúcia Homem (2012), teórica lacaniana, sobre Clarice Lispector. Já Bataille leria a posição de alguém efetivamente abandonado ao não-saber. E é na angústia do nãosaber, "na ruptura de qualquer possível” (BATAILLE, 1992, p. 66), que o homem aberto se descobre uma súplica. Quanto a Foucault, pode-se até esquecer do seu fascínio por Blanchot e Bataille na sua fase formativa. Basta lembrar que sua posição nietzscheana faz da exterioridade o lugar por excelência do pensador genealógicodesconstrutivo. Se por meio de Foucault, "o Dionísio se tornou arquivista" (SLOTERDIJK, 2012c, p. 107), é porque a exterioridade garante a possibilidade de enxergar os acontecimentos, os clarões contingentes que abrem os horizontes "das ordens possíveis" (id., ibid., p. 108). Não seria difícil explorar um pouco mais os tópicos desta lista e mostrar que todos eles remetem a Heidegger e a Nietzsche. Cumpre notar apenas que a obsessão constante por esvaziar o "sujeito" e ultrapassar a herança da filosofia da modernidade acaba conduzindo ao elogio semibudista do self negativo. Essas filosofias acabam por recomendar posições nas quais é impossível e impraticável viver a não ser para quem seja um escritor vanguardista, mas, ao mesmo tempo, produtivo academicamente. Tais posições tornaram-se hoje assunto de guetos e de especializações acadêmicas, maiormente na subcultura teatral e psi. $\mathrm{O}$ interessante em Sloterdijk é que em sua obra ele joga fora o sujeito moderno, mas não cai na dignificação do vazio, da desterritorialização, da impessoalidade poética ou da exterioridade, pois coloca no seu lugar o conceito de self ou de si mesmo ${ }^{20}$ revigorados pela tradição da psicanálise inglesa do grupo do meio (middle group). Essa operação

\footnotetext{
${ }^{20}$ Por outros caminhos, penso que um movimento semelhante se dá nas obras de Charles Taylor e de Paul Ricouer. Ambos utilizam-se da noção de self e de si-mesmo.
} 
sloterdijkiana é dotada de grande relevância, pois, com ela, o mais francês dos filósofos alemães supera e põe em xeque seus predecessores franceses. Não há dúvida de que a esferologia, ao trazer para o interior da filosofia fenômenos e conceitos inteiramente novos, logra circunscrever e relativizar o âmbito da experiência filosófico-literária francesa. Essa circunscrição é superadora, pois os fenômenos esféricos e a inclusão do nascimento e dos bebês no interior do discurso filosófico é algo inconcebível para as crianças de Heidegger e os meninos de Nietzsche.

Sloterdijk inaugura assim um novo paradigma para a filosofia do século XXI e renova as bases da conversação filosófica. Uma conversação mais ampla, mais aberta, mais complexa e menos extremista, aristocrática e vanguardista. Visto de hoje, o programa francês parece um tanto ingênuo e mal se entende como é que homens inteligentes podiam realmente acreditar que se mudaria de época ou de homem numa única década. A operação sloterdijkiana de transição paradigmática pode ser denominada de passagem ontotopológica de um lado para o outro do entre (Zwischen). Essa viragem é responsável por um deslocamento sui generis na filosofia contemporânea. Ela inibe o acento dominantemente ontomaníaco das filosofias recentes, que, na sua devoção ao evento (Ereignis), tendem a desprezar a continuidade do mundo instituído, seu "barulho" e falta de intensidade. Para o pensamento do evento, é como se o mundo estivesse em estado terminal e carecesse de revolução e de superação, e os filósofos fossem os heroicos guardiões de novas lufadas epocais. Se o chamado ético de Heidegger arrastou muitos para o outro lado do entre, em que o fundamental é expor-se ao descontínuo e ao incessante da irrupção do ser - o que envolve uma posição extravagante no limiar e na borda das culturas (o acontecimento do ser equivale ao grau zero da hermenêutica) -, a obra de Sloterdijk realiza uma migração para o outro lado do entre, o que implica uma virada de Stimmung e em um maior amigamento do mundo. Pensar os vários mundos por dentro, os mundos nos quais o ser humano se sustentou e encontrou lugar, e ainda assim o segue fazendo, é o legado do culturólogo e mega-abraçador de mundos, Peter Sloterdijk. Após a sua descrição dos processos morfogenéticos implicados na formação dos vários mundos desde a "préhistória" até a pós-história, muito da filosofia anterior soará ultrapassado. A memória monstruosa e a visão hiperbólica situam as questões da modernidade e da experiência do presente a partir de quadros muito mais amplos e exigentes que os até hoje praticados. A analítica do espaço e da forma, empreendidas por Sloterdijk - a sua resposta exaustiva à pergunta: onde estamos quando estamos onde estamos? -, trazem 
para a filosofia "uma forma filosófica nova do pensamento, do mundo e até mesmo da existência" (WERNTGEN, 2009, p. 223). Ainda é cedo para avaliar o impacto da renovação sloterdijkiana da filosofia. Não se trata apenas do efeito óbvio sobre a Teoria Crítica alemã, como atestam as polêmicas tanto com Habermas em $1999^{21}$ quanto com Honneth em 2009. ${ }^{22}$ Tão interessante quanto este debate com os representantes das últimas gerações da Escola de Frankfurt é a questão do impacto sobre a filosofia francesa do pós-guerra. Na medida em que o pensamento imunológico reposiciona a obra de Heidegger e a de Nietzsche, e o pensamento francês é fundamentalmente uma operação a partir de leituras desses dois filósofos alemães, ${ }^{23}$ a virada esferológica termina por problematizar e mostrar o esgotamento de grande parte das questões que compõem o "programa francês", segundo a expressão de Alain Badiou (2015).

Nesse sentido, a lição de Sloterdijk é a de que a filosofia não pode se aliar apenas ao rapaz do bonde. É óbvio que ela pode e deve pensar a não integração e a desintegração em suas formas mais variadas, mas se ela escutar apenas os desertores, os artistas, certas crianças e as singularidades, nada poderá compreender do integrar-se aos espaços no mundo. Este não é uma democracia ontológica e as hermenêuticas filosóficas da singularidade são insuficientes até no campo psi. Cabe à filosofia não pensar apenas os espaços do acompanhamento microesferológico, mas o grande espaço do mundo globalizado. É preciso que surjam filósofos à altura das complexidades imensas do mundo contemporâneo. Esses filósofos aguardados por Sloterdijk são seres já curados tanto da deserção quanto do desejo de revolução. ${ }^{24}$ Filósofos capazes de transitar por vários mundos e épocas e que possam compreender e dialogar com os verdadeiros revolucionários na revolução cronificada da atualidade: designers, consultores e arquitetos. Assim sendo, a filosofia antropológica dos lugares - a esferologia sloterdikiana - despede-se tanto da rebeldia ingênua quanto do páthos da

\footnotetext{
${ }^{21}$ A reconstrução detalhada desta polêmica encontra-se no texto "Sobre as Regras para o parque humano de Sloterdijk", de José Oscar de A. Marques, que é também tradutor do livro comentado, bem como de outras obras do filósofo alemão.

${ }^{22}$ O livro Die nehmende Hand und die gebende Seite (2010) é resultado da polêmica com Honneth em torno da obrigatoriedade do fisco e da doação voluntária.

${ }^{23}$ Quem assim o coloca é um digno representante dessa tradição: Alain Badiou em A aventura da filosofia francesa no século XX (2015).

${ }^{24}$ Uma interessante discussão sobre o tema da revolução encontra-se em Essai d'intoxication volontaire (SLOTERDIJK, 1999c, p. 57-67). Nessa entrevista, Sloterdijk recorda o ambiente revolucionário nos seus anos de formação na Alemanha. Em $O$ sol e a morte, ele conta que "era um adepto mais ou menos típico da velha Escola de Frankfurt e da cena alternativa dos anos 70, tomava parte nesse complexo depressivo e agressivo que então se manifestava como esquerda" (id., 2007, p. 18). "Nessa época vivíamos na ilusão de que era fácil mudar o tom vital da sociedade ao abrigo de uma ética da amizade e da amabilidade. Era a época da ofensiva dos pequenos grupos sonhadores" (id., ibid., p. 17).
} 
Teoria Crítica. Isso se deve fundamentalmente ao fato de que Sloterdijk parte da topofilia bachelardiana. Começar topofilicamente é começar da vida bem posicionada e do lugar alcançado. Como a instalação "de lugares para um estar-consigo logrado" (SLOTERDIJK, 2009a, p. 408) depende de encontros sintônicos com o aliado, o fenômeno da alienação não tem prioridade temporal nem lógica sobre o fenômeno do bom posicionamento. Nas palavras de Sloterdijk:

O escândalo de uma teoria da consciência feliz em meio ao culto à infeliz se dilui enquanto se admite que uma teoria positiva da posição íntegra é toda uma dimensão mais rica que uma teoria crítica, que adquire forma como sintoma de um transtorno da capacidade de participação. (id., ibid.)

É ao longo de Esferas II, ao reconstruir a história das formas de autoarredondamento e autoclimatização feitas por esses criadores de lugar que são os seres humanos, que Sloterdijk se depara com o momento em que surgem as experiências de alienação e distanciamento. De início, a experiência de estar contido em um interior, em uma magnitude uterotécnica e autoprotetiva, prescinde de muros e paredes. Inúmeros grupos criaram incubadoras sem paredes de solidariedade esférica. Os muros e as paredes surgem como magnitudes vivas que trabalham pela animação do espaço interior. Mas quando

as paredes se tornam estranhas, monumentais, quando não sugerem nada, e sua coordenação com um espaço interior próprio já não é conseguida por todos, mas apenas por alguns privilegiados, então aparece a necessidade de distinguir os muros (id., 2004a, p. 198).

Essa experiência acontece tanto em relação ao muro dos outros, dos inimigos, quanto aos intramuros, isto é, os muros no interior da própria cultura, como é o caso das grandes sociedades hierárquicas. Nesse contexto, alguns dos que estavam juntos dentro começam a experimentar um estranhamento em relação às "próprias paredes" (id., ibid., p. 199). O envoltório antes animador e próprio desaparece e a vida que se experimentava como viva e consigo mesma naquele interior passa a sentir-se num cárcere ou numa "cápsula estranha" (id., ibid., p. 200). Ao não se sentir mais amparada e protegida, a vida começa a sonhar com uma evasão e articulará em esquemas gnósticos toda sua reserva "frente ao ser no mundo" (id., ibid., p. 199). 
O sentimento de estranheza radical e de que a alma é uma exilada caída no cárcere do mundo é a equação gnóstica fundamental. A compreensão do mito gnóstico que diz dessa alma que anseia por algo "outro" é um capítulo importante na obra de Sloterdijk, ${ }^{25}$ pois as "teses gnósticas" servem como chave hermenêutica para decifrar o páthos do par abandono-redenção presente em vários discursos filosóficos que não se apoiam no "cantus firmus do Ser" (id., 2011, p. 161). É o caso da primeira geração da Teoria Crítica. Enquanto na gnose antiga há narrativas que contam deste ser-jogado e práticas ascéticas que reconduzem a alma à alegria e à liberação, a gnose moderna encarnada no pensamento de Adorno se contenta

em confirmar constantemente o caráter lúgubre do cenário do mundo, no qual os aspectos da felicidade perdida e esperada só podem pintarse de escuro. Ela pinta um quadro de grande austeridade [...] dominada pelos arcontes modernos, os malignos administradores do mundo sem vida: a abstração da troca, o despotismo, a frieza burguesa (id., ibid., p. 159).

Se estar no mundo equivale a estar em um corredor polonês ou em um campo de concentração, então o verdadeiro só brilha no instante em que a individualidade escapa das garras da máquina do todo. Para Sloterdijk, Adorno repete ad nauseam o mantra gnóstico e põe todos os seus "operadores lógicos" a serviço de uma "cena invariável" (id., ibid., p. 167). O ferrão crítico da Teoria Crítica é apenas um outro nome para o elemento messiânico. ${ }^{26} \mathrm{Na}$ Teoria Crítica, Jerusalém e Atenas entram num arranjo no qual a salvação se torna capítulo da epistemologia. Enquanto teorias tradicionais fixam os indivíduos na grelha do universal, a teoria que se apresenta "como crítica pretende invalidar as identificações existentes e resgatar as coisas singulares das garras da razão registradora" (id., ibid., p. 157).

$\mathrm{O}$ interessante é que nessa versão adorniana do Ge-Stell heideggeriano, o mundo criticado, o existente, ao invés de aparecer como algo cada vez mais mobilizado

\footnotetext{
${ }^{25}$ Sloterdijk publicou com Thomas Macho Weltrevolution der Seele: Ein Lese- und Arbeitsbuch zur Gnosis von der Spätantike bis zur Gegenwart (1993). O livro contém "algo como uma dedução metafísica do 'princípio da esquerda' e, ironicamente, também uma pré-história da Escola de Frankfurt, uma linha fina e intrincada que vai de Alexandria ao Instituto de Investigação Social e passa pelo Auditório VI da Universidade Johann Wolfgang Goethe" (SLOTERDIJK, 2007, p. 26).

${ }^{26}$ Um dos exemplos que comprovam o elemento messiânico é a famosa passagem citada por Sloterdijk do último aforismo de Minima Moralia. Cita-se aqui seu trecho inicial: "Da filosofia só cabe esperar, na presença do desespero, a tentativa de ver todas as coisas tal como se apresentam do ponto de vista da redenção. Não tem luz o conhecimento senão aquela que se irradia sobre o mundo a partir da redenção: tudo mais se esgota na reprodução e se limita a peça da técnica. Caberia construir perspectivas nas quais o mundo se ponha, alheado, com suas fendas e fissuras à mostra tal como alguma vez se exporá indigente $\mathrm{e}$ desfigurado à luz messiânica" (ADORNO, 2008, p. 245).
} 
e desrealizado, aparece sempre descrito com imagens de solidez, petrificação e rigidez. Esse é um dos exemplos dados por Sloterdijk, que mostra que a Teoria Crítica envelheceu e que a sua síntese particular de sociologia, messianismo e estética radicalizada já não serve mais como relógio epocal. A ideia do todo como fortaleza dura, a "jaula de ferro" weberiana de cujos tentáculos devemos salvar o individual, caducou, porque as formações modernas são elas próprias caóticas e intangíveis. Não há muito a ser quebrado quando se lida com estruturas

disparatadas, como redes e espumas, com turbulências e derivas indeterminadas, com tentativas de ordenação cindidas por grandes forças centrípetas e em estado de crônica excitação devido aos riscos imanentes de sofrer catástrofe (id., ibid., p. 166).

Sloterdijk considera que, quando Adorno e Horkheimer adotavam o termo "o existente", mesmo para o mundo tendencialmente virtual e flexível, é porque usavam o idioma gnóstico e praticavam a "metafísica negativa como crítica do mundo" (id., ibid., p. 165). Falavam mais como gnósticos redivivos do que "como sociólogos" e "homens do seu tempo" (id., ibid.).

Essas breves considerações sobre a Teoria Crítica não podem ser concluídas sem a lembrança de que Sloterdijk só acertou o seu relógio epocal ao longo do percurso e que ele próprio se utilizou do termo crítica e usou conceitos como o de alienação para referir-se a processos inquietantes (é importante lembrar que Sloterdijk começou sua vida intelectual imerso nas obras de Adorno e Bloch!). Um exemplo disso é o livro $A$ mobilização infinita, de 1989, no qual Sloterdijk tenta ainda uma crítica da cinética política, o que representa uma tentativa de Teoria Crítica alternativa. Nessa obra, a modernidade é compreendida como um ser-para-o-movimento sem fim, o que equivale a um ser-para-a-aniquilação. Ele propõe então uma crítica da mobilização em termos de exercícios de desmobilização. A resposta à pergunta: "Há sequer para nós uma possibilidade de resultar das energias do sujeito alguma outra coisa que não seja aceleração, enriquecimento, pesquisa e aquisição de poder no mundo exterior?" (id., 2002a, p. 65). Responder positivamente a essa pergunta é estar implicado na diferença entre movimento para mais movimento e movimento autêntico. Como escapar da catástrofe mobilizadora? A alternativa metafísica, com suas receitas imobilistas e eternizantes não oferecem antídotos contra a aceleração da cultura histórica no seu deslocamento de Titanic até o iceberg Tchernobyl, mesmo porque é a própria cinética 
da metafísica que se converte em cinética moderna. "A antiga metafísica, enquanto paixão pela imobilização e pela autoconcentração, é a acumulação originária da subjetividade que, na modernidade, se atira à frente como mobilização passional" (id., ibid., p. 99).

Não é difícil imaginar que o diagnóstico da modernidade em termos cinéticos leva a um amigamento maior com a escola de Freiburg do que com a de Frankfurt, apesar do uso do termo crítica. Para Sloterdijk, a teoria frankfurtiana não é desmobilizadora porque, como estética negativa,

ela se desencontra do fator crítico, porquanto argumenta de maneira latente sem referência ao mundo; como teoria da ação, renuncia à diferença em relação ao seu objeto, na medida em que o procedimento comunicativo atua, manifestamente, como princípio de mobilização (id., ibid., p. 98).

Já com essas poucas palavras dirigidas a Adorno e Habermas, Sloterdijk, o então autointitulado "heideggeriano de esquerda", antecipa as polêmicas futuras com Habermas e Honneth, tão previsíveis quanto às de Luckács com Nietzsche e de Adorno com Heidegger. ${ }^{27}$

\section{3 Outras considerações microesferológicas}

A esferologia slotedijkiana é uma contribuição filosófica que realiza um afastamento tanto da xenofilia das ontologias contemporâneas quanto uma saída para a famosa equação do poeta Gottfried Benn: “Ao olhar para mim mesmo, eu percebo dois fenômenos, a sociologia e o vazio" (apud SLOTERDIJK, 1999c, p. 80). Se, no primeiro caso, o elogio da estranheza esquece que fomos bebês dependentes, bebês cujo próprio lugar-para-ser ou lugar-de-ser foi possibilitado por úteros e colos, e que nem sequer chegaríamos a ter relações com as coisas, se antes não tivéssemos sido capazes de brincar - e que teríamos ficado despedaçados se a estranheza imperasse desde o início e as mães fossem levinasianas -, já no caso da sentença do poeta Benn, a esferologia abre

\footnotetext{
${ }^{27}$ Sobre tal questão remeto ao texto de Jean-Pierre Couture "A Public Intellectual", no qual é feito um "mapa das colisões intelectuais no céu da Alemanha" (COUTURE, 2012, p. 103).
} 
os olhos para o terceiro elemento. ${ }^{28}$ Nem o completo disforme "quase budista [...] do budismo made in Germany (id., ibid., p. 22), nem a figura ou forma morta. É estranho que esta dupla alternativa, conversora da filosofia num mero gueto de desconstrucionistas ou de meninos desencontrados, tenha ganho tanto terreno. ${ }^{29} \mathrm{De}$ qualquer modo, a esferologia surge após o esgotamento do páthos analítico nos anos 1930 e torna possível "formas sintéticas mais livres" (id., ibid., p. 86). A experiência base da esfera é a de que saímos de nosso próprio vazio e mergulhamos extaticamente em ambiências de simpatia e participação. Esse lugar, ainda que invisível, é o mais real. É o "ar no qual nós temos a vida" (id., ibid., p. 83), o oxigênio no interior do qual respiramos. A sociologia e o vazio nada dizem desse êxtase essencial, do anseio de mergulho naqueles que acabam de chegar ao mundo. Vale dizer que o caroço surreal, o núcleo mágico e abundante, é o próprio fenômeno da imersão convivial $^{30}$ completamente não formulado pela filosofia e inacessível ao olhar fenomenológico de Husserl, Merleau-Ponty e Heidegger.

Um dos exemplos mais interessantes da força calórica convivial é a emergência da facialidade; a protração do rosto. É espantoso compreender que o próprio vir à luz e o revelar-se do rosto estejam ligados aos mimos luxuriantes - o olhar-se uns aos outros - no interior das ilhas incubadoras que são as primeiras cápsulas culturais. Foi por meio de altas temperaturas de irradiações recíprocas nos namoros mútuos dos sapiens que a clareira do ser abriu-se no rosto e o homem se tornou aberto ao próximo. O rosto faz rosto, eles "se criam de uma certa maneira reciprocamente; florescem em um círculo oscilante de abertura luxuriosa recíproca" (id., 2003, p. 157). Nossos ancestrais se plasmaram mutuamente no denso microclima de atenções e mimos cujas temperaturas afetivas podem ser lembradas ainda hoje naqueles momentos em que paramos para sorrir e simpatizar com lindos rostos de bebês e de crianças miúdas.

Para Sloterdijk, a abertura da facialidade, a migração dos focinhos que se cheiram em direção à clareira do ser no rosto é possibilitada por esse ir e vir do jogo

\footnotetext{
${ }^{28}$ No livro em que cita a passagem de Gotfried Benn, Sloterdijk esclarece: "Eu creio, de minha parte, que quando se olha em si, é, entretanto, uma outra coisa que aparece, uma terceira experiência. Não é a sociologia, não é o vazio, é um contexto esférico" (SLOTERDIJK, 1999c, p. 80)

${ }^{29}$ No livro Estranhamento do mundo, Sloterdijk escreve: "Parece-me plausível ver nas excessivas linguagens do mundo de expressão moderna algo mais do que uma tendência a longo prazo para a psicotização do espírito do tempo. Manifestam simultaneamente uma experiência de profunda liquidação do ímpeto terapêutico de homens contemporâneos" (SLOTERDIJK, 2008a, p. 166).

${ }^{30}$ É apenas à luz das catástrofes do convívio que proposições como: "não sou um homem, sou dinamite; não sou cidadão, sou lixo; não sou sujeito, sou uma máquina desejante; não tenho congêneres, sou um meteoro" (SLOTERDIJK, 2008a, p. 166) podem ser compreendidas e colocadas sob suspeita.
} 
interfacial, sendo que o núcleo mais amistoso e alegre dele é o "terno entretenimento do mútuo iluminar-se do rosto de mães e filhos no período do bonding pós-natal" (id., ibid., p. 163). A protração do rosto, a emergência da facialidade, é uma condição universal e é apenas sobre ela que se assenta a semântica fisionômica e a inscrição do tipo rótulo-facial. Assim como, heideggerianamente, a verdade em sentido originário, isto é, a manifestabilidade de uma coisa, possibilita a verdade no sentido derivado da correspondência (adequação) da proposição com essa coisa manifestada, Sloterdijk também diferencia o caso universal da facialidade de suas variações culturais específicas. Deleuze e Guattari, por não terem feito esta distinção básica, dizem que o rosto é Cristo e condenam o rosto como uma cédula de identidade e fichamento. ${ }^{31}$ Entretanto, esse tipo de predomínio do rosto caracteriológico-delator só acontece muito tardiamente, na época da formação de povos e de agrupamentos maiores. ${ }^{32}$ É apenas em grandes grupos que é necessário remodelar as "orientações cognitivas em um entorno composto de uma maioria de não familiares e desconhecidos (id., ibid., p. 163). Por outro lado, nas grandes culturas há ícones-tipo de facialidade, e se o rosto dos europeus foi moldado ao longo de gerações pelas representações do Cristo, o mesmo acontece, por exemplo, no mundo hindu, chinês e japonês, no qual a modelação fisionômica depende das imagens do Buda. Desse modo, se há rostos cristãos doloridos e abertos à transcendência, há também rostos búdicos flutuando em uma "disponibilidade de ressonância (id., ibid., p. 168) e também rostos poderosos de grandeza oriundos das efígies romanas.

Se é impossível ver um rosto de César em posição de lótus, isto é sinal de que o rosto não é só Cristo, e se Deleuze peca por não discriminar a protração do rosto e o rosto fisionômico semântico, o problema do pensamento de Levinas é partir de uma experiência do rosto que de modo algum tem qualquer tipo de confirmação ou validade a não ser na "ética dual judaica" (id., ibid., p. 206), que é a matriz do pensamento levinasiano. Como pensar, excluindo a demanda de intimidade de uma criança? Se o rosto do outro permanece "infinitamente transcendente, infinitamente estranho" (LEVINAS, 2008, p. 188); se o rosto do outro é intransponível e incompreensível e “recusa-se à posse, aos seus poderes" (id., ibid., p. 192), então certamente a alegria que é portadora da emergência do rosto daria lugar a uma catástrofe interfacial

\footnotetext{
31 "É isso ser identificado, fichado, reconhecido: um computador central funcionando como buraco negro e passando sobre um muro branco sem contornos" (DELEUZE \& PARNET, 1998, p. 26).

${ }_{32}$ No capítulo 2 desta tese há um elenco dos agrupamentos humanos segundo sua magnitude e as correspondentes morfologias imunológicas.
} 
desfiguradora e destruidora de rosto. Nesse sentido, parece que a ética levinasiana enquanto advoga uma alteridade radical sem misturas e contágios é um tanto mortífera.

Esferas I abandona tanto o páthos levinasiano das filosofias da alteridade estranhada quanto dos que partem (como Heidegger) da pseudoindependência do indivíduo para começar das situações misturadas de contágio e imersão comum. Quando um duo está compenetrado é até difícil usar o termo relação; se a fusão é bem sucedida, a própria percepção do outro como outro fica anulada. O divíduo é o fenômeno mais originário e por mais que analisemos e picotemos um indivíduo, os seus últimos átomos não serão seus, mas complexos polivalentes envolvendo misturas amalgamadas. Nesse sentido, como diz Gabriel Tarde, citado em Esferas III, cada indivíduo seria ele mesmo uma "sociedade". O topar-se com um outro radicalmente outro pressupõe imunizações mal sucedidas e narcisismos duais colapsados. Nesse contexto, vale notar que, no caso heideggeriano, ainda que a sua analítica saliente o caráter do ser-com (Mit-sein) do ser-aí humano, a análise efetiva deste redunda numa apresentação da tagarelice (Gerede). É como se os seres humanos só pudessem trocar entre si falas vazias. Tudo não passa de flatulência vocal quando o verdadeiramente importante é a antecipação existencial da possibilidade mais própria, a do morrer considerado do ponto de vista existencial em sua permanente iminência e eminência. A cotidianidade e o outro aparecem como barulho a ser vencido pela finitização rememorada e assumida. Não há declaração de amor ou de amizade, nem gestos ônticos de cuidados comparáveis ao gesto de remeter o outro ao estranho que habita nele.

Em uma analítica da existência desse tipo, explica Carla Cordua, não há lugares para a "intimidade, nem para a colaboração, nem para a solidariedade" (CORDUA, 2008, p. 191). Contrariamente à ficção individualista, Sloterdijk mostra em Esferas I que já no interior do ambiente pré-natal o ser-aí incipiente é acompanhado e nutrido por um "com" discreto e silente que é o íntimo placentário. No capítulo 5 de Esferas $I$, intitulado "O acompanhante originário", o pensador de Karlsruhe deixa claro que desde o início está também presente de um modo não objetivo uma espécie de “obscuro irmãozinho que nos foi colocado ao lado para que a noite fetal não fosse demasiadamente solitária [...], uma irmãzinha que está aí, à primeira vista, para dormir contigo no mesmo quarto" (SLOTERDIJK, 2003, p. 326).

O complementador originário ou o não-objeto-com é o aliado cuja marca está presente no umbigo de cada um. O umbigo é o desmentido da solidão e do clichê existencialista, pois ele aponta para o fato de que logo após nossa chegada ao mundo 
aéreo, sempre chegou também um segundo, o conformador do nosso primeiro espaço. Para além das consequências culturais do esquecimento do umbigo, ${ }^{33}$ o que a análise sloterdijkiana da placenta prova é que, desde a gênese, estamos envolvidos em duos contínuos e é o "com" (das Mit) que funciona como um primeiro localizador espacial de um nascente lá (o íntimo placentário) e um aqui (o pré-sujeito fetal). Esse vai e vem indica um primeiro posicionamento e mostra que o estar comigo já pressupõe um pluralismo de dois.

\footnotetext{
${ }^{33}$ O homem moderno é entregue diretamente às mães ou aos coletivos "sociedade" e "povo". O niilismo placentário impede a remissão ao gênio aliado e ao autêntico companheiro de cada um; uma Eurídice que desceu ao Hades do lixo hospitalar para que nós pudéssemos vingar.
} 
2. ANALÍTICA DE MACROESFERAS 


\subsection{Transições e culturas}

As microesferas iniciais precisam explodir em algum momento. Se retomarmos o pacto pneumático entre Javé e Adão (anteriormente mencionado como paradigma da intimidade cocriadora), logo percebemos que ele é desfeito no momento em que Adão se interessa por outras vozes como a da serpente e a da mulher. Ao ficar interessado nessas vozes acessórias, Adão "descobre o que os teólogos chamaram sua liberdade" (id., ibid., p. 55), o que significa "uma certa flexibilidade espontânea frente à sedução por parte de um terceiro" (id., ibid.). Surgem desejos e interesses múltiplos, e já desde o primeiro movimento de liberdade, o ser humano sai da dúplice-unidade da sonoridade pura que vigora entre Javé e Adão. A díade interdevocional na esfera comum de espaço interior se rompe. A expulsão do paraíso é o destino. Expulsão do paraíso é "um título mítico para a catástrofe esferológica primitiva, que em terminologia psicológica se transcreveria aproximadamente como o trauma geral do desmame" (id., ibid.). Sem o desmame, sem a catástrofe primitiva, não haveria psiquismo. O psiquismo é a presença do complementador inicial agora vivo em mim após a sua retirada.

Há uma corrupção inevitável do espaço bipolar dos copertencentes e a aparição do terceiro, quarto e quinto. Rompe-se a homeostase originária e a vibração comum na "câmara de ecos animada". A felicidade do dois-em-um e do um-no-outro dá lugar à infelicidade do enumerar. Quanto ao modo do estouro das bolhas, ele depende das culturas. Aos poucos, entre os aliados íntimos se

\footnotetext{
introduzem objetos de transição, temas novos, temas acessórios, multiplicidades, novos meios; o espaço antes íntimo, simbiótico, atravessado por um único impulso, abre-se à diversidade neutra, na qual a liberdade só vem dada com o estranhamento, a indiferença e a pluralidade (id., ibid., p. 57).
}

Se o interior simbioticamente oco de Adão passa a ser ocupado por preocupações e entretenimentos, o mesmo acontece com as crianças que ao abandonarem seus quartos de brinquedo encontrarão também usinas atômicas, coleguinhas indiferentes e uma série de outras coisas que não poderão ser animadas e convertidas em algo próprio e interior.

A abertura para a história é essa passagem do mundo da partilha íntima do espaço cocriado da ressonância esférica para o mundo multipolarizado dos adultos. Com 
a catástrofe da esfera primitiva, os adolescentes sofrem um "shock de transcolonização, um desenraizamento existencial: separam-se da sua condição infantil porquanto cessam de viver completamente à sombra do outro identificado e começam a ser habitantes de uma esfera psicossocial ampliada" (id., ibid., p. 59). Cresce o estranho e o exterior. Se o adolescente não estivesse dotado das recordações do campo simbiótico, ele não conseguiria integrar e superar o "trauma do intruso", nem se manter inteiro em lugares estranhos. O movimento de consolidação do espaço interior move os homens e as culturas. Assim como um adulto acaba por chamar um câncer intruso por um nome próprio, as culturas agem sempre na direção de domar e avizinhar o externo, o fora e o sem sentido. Em termos esferológicos, ordem é "sobretudo o efeito de uma transferência de interior ao exterior" (id., ibid., p. 61). Esse é o trabalho das culturas. Elas fazem uma espécie de "fagocitose" do estranho, incorporando-o ao mesmo, como o leopardo de Kafka, que, ao entrar no templo pela segunda vez, já começa a fazer parte do ritual.

Sloterdijk escreve que as "imagens metafísicas do mundo da velha Europa e da Ásia são, de fato, os recolhimentos ascéticos mais vivos do estranho, morto, exterior no círculo dos grandes mundos interiores animados de sentido e entretecidos de escritura" (id., ibid.). Os arquitetos de espaços interiores, que somos nós, precisam desde o início exorcizar o fora e congregar no interior animado desde a minhoca até a estrela. As grandes culturas são arredondamentos simbólicos de sínteses gigantescas. É por isso que Sloterdijk considera Hegel "o último monumento europeu desta vontade de recolher toda negatividade e exterioridade no interior de uma catedral redonda logicamente reunida" (id., ibid.). Mas um culturólogo sabe que as grandes sínteses do tipo filosófico dependem de sínteses militares, políticas e arquitetônicas. Esferas II mostrará que ali onde os arquitetos mesopotâmicos terminaram a construção de muralhas e de centros monumentais, os filósofos gregos podiam começar suas construções especulativas. De certo modo, a construção arquitetônica foi um a priori material da filosófica. Como para o culturólogo a questão central é de design imunológico, a filosofia é para ele um tipo de design presente num certo tipo de cultura, mas o seu ineditismo imunológico vai residir apenas na morfologia e no fato de que ela - a filosofia - dependerá do compasso dos geômetras a conceber a cidadela do ser e não mais do braço dos escravos para construir a cidade das muralhas empíricas.

Se os arquitetos mesopotâmicos experimentaram morfologicamente "a possibilidade de edificar um grande mundo como mundo próprio e interior autoincubante" (id., 2004a, p. 272), Sloterdijk lerá nas arquiteturas monumentais 
amuralhadas do velho oriente um primeiro murmúrio daquilo que um dia será o sujeito transcendental, pois a cidade amuralhada "se recolhe em si mesma como condição autossuficiente da possibilidade de um mundo compreendido, autorregulamentado, autossuficiente e autossustentante" (id., ibid., p. 270). Milhares de homens durante milhares de anos e de gerações "foram empregados apenas para o trabalho no cercamento do receptáculo da totalidade" a fim de "testemunhar que tudo o que é pode ser contido em uma forma" (id., ibid.). Vale dizer que, na questão da forma do todo, a arquitetura mesopotâmica "pensou" aquilo que a filosofia apenas posteriormente enunciará.

Foi a catástrofe política de Atenas, como mostra Esferas II, que levou os gregos no "acontecimento Platão" a pensar uma imunidade em uma cidade invulnerável aos ataques empíricos. A filosofia traz assim uma nova equação de residência: não mais a cidade empírica onde o homem grego pode ser morto e sua família estuprada e frita pelos persas ou pelos piratas, mas a casa cósmica e o residir no ser, uma residência imunizada contra os tumultos da vida, residência tão iluminada e plena, que nela a exterioridade é impossível. O filósofo aparece então como um "expert em outros lugares" (id., ibid., p. 314) ou o "agente imobiliário [...] que faz propaganda entre seus concidadãos para que participem na mudança" (id., ibid., p. 313) da cidade-devir para a verdadeira cidadania no universo imorredouro. ${ }^{34}$ É nesse contexto que as asceses vão servir para o "fortalecimento deste sistema mental de imunidade" (id., ibid., p. 320).

Quer se trate da arquitetura na Mesopotâmia ou da filosofia grega, a questão é como habitar no grande. E de como o grande pode continuar sendo casa para os homens no mesmo sentido em que corpos maternos o foram. Essa é a questão da macroesferologia e do volume II da trilogia Esferas. Esferas II trata da transferência da segurança do "ventre" (Bolhas, Esferas I) para as "belezas racionais do volume geométrico" (Globos, Esferas II), segundo a expressão bachelardiana. Veremos a seguir qual é o projeto epocal de imunização que nasce na filosofia grega e se estende até o final da Idade Média e conhece um colapso irreversível na modernização do mundo. Mas antes de passar à discussão dessas questões ligadas ao grande (ao pensamento metafísico e o seu correlato político, a forma-imperial), é necessário acrescentar

\footnotetext{
${ }^{34}$ Se nos mundos pré-metafísicos a imunidade é guerrilheira e depende de combates constantes em vários flancos entre energias de ataque e energias de defesa, no mundo metafísico, essas "manadas de forças combatentes" (SLOTERDIJK, 2009a, p. 180) dão lugar a uma única defesa: alma, psiché é o nome para a segurança em uma forma inviolável. Incluir-se nessa forma é ganhar a imortalidade. Daí o problema da superimunidade metafísica: ela protege a vida apenas na medida em que a nega e a subordina ao morto e ao "espiritual, exatamente aquilo que não pode morrer porque jamais viveu" (id., ibid., p. 185).
} 
algumas considerações sobre as pequenas etnosferas que floresceram sobre a Terra antes desta enorme multiplicidade ter sido absorvida por formas maiores. Nos clãs, tribos e povos o que está em jogo para os seres humanos é já e sempre a questão de "desmentir seu desamparo na exterioridade" (id., ibid., p. 138) e fazer a passagem do exterior ao interior mediante gestos criadores de mundo.

A primeira e mais originária criação é a da climatização simbólica do espaço comum. Quem diz "clima", diz aqui do microclima, do tom e da afinação do ânimo entre aqueles que estão estreita e fortemente unidos. Este clima reinante Dentro, no interior do espaço comum, é a atmosfera. Ela é o primeiro "em" daqueles que estão imersos no mundo e é simultaneamente autogerada por eles e os ultrapassa. A atmosfera é uma "magnitude comunitária" (id., ibid., p. 130) e ela não é palavra nem coisa, mas "algo mais extenso, anterior e penetrante que ambas, é algo que não quiseram reconhecer nem as ciências positivas nem as teorias discursivas" (id., ibid., p. 129).

Substancialismo e logocentrismo não enxergam o realissimum daquilo que é o mais originário do convívio humano. Embora Sloterdijk esteja aqui desenvolvendo a climatologia existencial do jovem Heidegger, ${ }^{35}$ ele o critica na medida em que salienta o caráter comunitário da produção do clima comum. A produção da comunicação sutil endoclimática não é, de modo algum, assunto individual. O nicho endoclimático como lugar base para os seres humanos é a construção primeira desses mesmos seres humanos. Isso significa que o ser-aí só existe no interior de um espaço que ele mesmo cocriou. É um espaço insulflado e partilhado. A climatização é simbólica, pois enquanto o céu de um povo leva o nome de um deus inspirador, a árvore, para outro, não é sossego ou emboscada, mas residência de um espírito benfazejo. Isso mostra que o seraí jamais existiu na "imediatez da natureza" ou "junto aos fatos mesmos" (id., 2003, p. 52). Evidencia-se que os seres humanos dependem de "sentimentos partilhados e suposições comuns" (id., ibid.). Se no interior do continuum dos climas etnosféricos aparecessem muitos neofílicos ${ }^{36}$ ou muitos traidores-negadores, quebrar-se-ia o fluxo das transmissões e das inspirações comuns. Se Nietzsche e Cioran ou Beckett não fossem fenômenos modernos, as etnosferas entrariam em catástrofe climática e desapareceriam. Quem desfaz a suposição comum e o sentimento partilhado implode o

\footnotetext{
35 "Poder-se-ia considerar a obra precoce de Heidegger como a carta magna de uma climatologia não tentada até então" (id., 2004a, p. 129).

${ }^{36}$ Sobre neofílicos e neofóbicos cf. Has de cambiar tu vida (Deves transformar tua vida), de Sloterdijk (2013).
} 
"Dentro", no qual os que estão aliados tentam impugnar a vulnerabilidade e desmentir a imensidão do desamparo no exterior.

De acordo com a antropologia filosófica de Sloterdijk, que congrega a ontologia de Heidegger, a inversão da antropologia de Gehlen, com sua síntese de antropologia e etnologia empíricas, e questões trazidas por Max Scheler, os seres humanos são "criaturas do seu interior [...] na forma da imanência que lhes pertence" e "só crescem na incubadora de sua atmosfera autogerada" (id., ibid.). Sem o continuum dessa estrutura imunitária, os seres humanos veriam interrompidos os processos de transmissão geracional. É necessário que os eventos catastróficos e as ameaças possam ser incorporados de modo que as microesferas aumentem o âmbito do seu próprio raio. É nesse contexto que aparece o problema da morte: não tanto a minha própria morte, como queria Heidegger, mas a morte do outro, daquele que foi meu próximo e aliado. Ela não pode impor o fim e o desaparecimento de um mundo, mas deve ser integrada de modo que - ao ser assimilada no interior esférico - impulsione a ampliação da própria esfera. A morte provoca uma reação imunitária que é criadora de espaço, pois, já nas hordas arcaicas, a visão do morto adquire caráter ritual, e o destino do morto é ser colocado em um "grande anel em torno da esfera dos vivos". Surge o culto aos antepassados, e a localização dos mortos num "círculo de proximidade" (id., 2004a, p. 151) os mantêm separados e simultaneamente ali. Quando esses grupos arcaicos não se remetem mais apenas aos familiares que convivem, mas a uma esfera que inclui também os ausentes, Sloterdijk afirma que isso "constitui o contorno mínimo de uma cultura", pois culturas são para ele "conformações esferopoiéticas que alimentam as recordações dos mortos determinantes e os propagam através das gerações" (id., ibid.), e as esferas são receptáculos dinâmicos que se transformam e crescem. Dado que é necessário continuar a viver após a perda do aliado e que não se há de morrer junto com ele, é preciso preencher o vazio dessa ausência com substituições criadoras. É isso que significa ingressar em tradições: o ausente importante "permanece presente nas recordações como advertência, como fantasma, como missão, como saber" (id., 2003, p. 54). É nesse sentido que a morte - esse estressor de esferas - gera uma ampliação do espaço ao obrigar os enlutados a criarem uma espacialidade imaginativo-simbólica próxima e distante para os mortos. Quando isso acontece e surge uma coexistência de vivos e mortos "em comunhões rituais dentro de um horizonte conjurado" (id., 2004a, p. 152), então, para o filósofo de Karlsruhe, estamos no interior de um desenho de mundo 
em sentido forte. É aberto a este mundo e aos mortos ${ }^{37}$ que "se assenta o ser-aí genuinamente humano [...] gerador de espaço" (id., ibid.).

São os desenhos de mundo específicos, as variadas "casas do mundo", que a esferologia deve descrever. Assim, à fenomenologia microesferológica do primeiro volume segue a apresentação dos mundos dos pequenos conjuntos (clãs e tribos), passando por estruturas médias (povos) até a macroesfera de ordem superior em que a inclusividade atinge o todo. Pode-se formular isso de outra maneira e dizer que a obra de Peter Sloterdijk é uma espécie de hiperarmazém de mundos ou mega-armazém de morfologias imunológicas. Parte dos casais aliados para os mundos pré-metafísicos dos clãs, tribos e bandos passa pelos mundos metafísicos dos impérios até o mundo plural da modernidade. Essa exposição megalômana dos mundos não é apenas um exibicionismo de erudito, mas algo vivo que concerne e implica qualquer leitor de hoje, pois a narração das múltiplas casas do mundo ilumina o entendimento do local onde nos encontramos agora. Sloterdijk é um pensador do espaço. Com ele, já não perguntamos mais pelo "quem", como na tradição existencialista, mas pelo "onde". Filosofia para ele é descrição do lugar e das várias espacialidades.

Outra novidade do pensamento sloterdijkiano é que, para se aproximar e dar a ver as geometrias vitais das morfologias imunológicas, ele "abre o estilo teóricoacadêmico a uma polifonia de arquivos, formas, estilos e meios de discurso", contando com isso com a "reinvenção da figura do escritor-filósofo - a linhagem francesa do philosophe-écrivain" (WERNTGEN, 2009, p. 225-226). Esse tipo de escrita libera a filosofia do peso do jargão filosófico e permite, como acrescenta Werntgen, reconectar o pensamento ao contexto elementar de verdade e expressão. ${ }^{38}$

\footnotetext{
${ }^{37}$ Esferas III retomará ainda uma vez mais a discussão da morte ao apresentar as nove dimensões da antroposfera. Uma dessas nove dimensões é o thanatotopo, uma vez que a cápsula cultural da "ilha humana" é necessariamente visitada pelos mortos. Cf. p. 337-356.

${ }^{38}$ Nesse sentido, Sloterdijk não é herdeiro apenas de Heidegger e de Spengler, mas também de Thomas Mann e de Robert Musil. Prova disso é o romance A árvore mágica (1985) cujo subtítulo é "O surgimento da psicanálise no ano de 1785. Tentativa épica com relação à filosofia da psicologia". Nessa obra ficcional, Sloterdijk trabalha romanescamente os temas que integrarão o capítulo 3 de Esferas I: "Seres humanos no círculo mágico para uma história de ideias da fascinação da proximidade". Esse capítulo trata da magia nos inícios da modernidade e do magnetismo animal e mostra como a magnetopatia de Mesmer e seus discípulos interessou a filósofos como Fichte, Schelling e Hegel. Tanto as curas magnéticas quanto o encantamento da magia erótica dependem "da capacidade do lado passivo para alienar-se plenamente na relação com o polo ativo. Assim como a magia do amor está condicionada pela disposição a sucumbir ao influxo por parte dos fascinados, assim as curas mesmerianas pressupõem uma disposição sem limites por parte dos pacientes à subordinação ao fluído médico" (id., 2003, p. 239). Sobre a narrativa literária na obra de Sloterdijk, cf. o artigo de Efraín Kristal "Literature in Sloterdijk's Philosophy" (ELDEN, 2012, p. 147-164).
} 
Não são apenas os pequenos mundos que dependem da continuidade dos climas e das atmosferas etno-esféricas. Também os povos e os impérios dependem da manutenção de processos de autoinspiração. Se a autoinspiração resfria, um povo pode desaparecer em pouco tempo ou ser dominado pelo inimigo. A autoinspiração ou inspiração autogerada são as etnotécnicas e é através delas que "gerações se colocam de acordo unanimemente a dez mil, cem mil, às vezes milhões de indivíduos com respeito a espíritos superiores comuns e a ritmos, melodias, projetos, rituais e cheiros próprios" (SLOTERDIJK, 2003, p. 62). Desde a culinária até o que fazer com um cadáver, são suposições comuns e gestos partilhados pelo grande número dos reunidos e cocalibrados na mesma etno-esfera. Sem essas comunhões hermenêuticas de mundanidade, para usar termos heideggerianos, não se constituiria a cápsula cultural que é lócus e ilha de existência de um povo. Se povos que duram "demonstram seu gênio etnotécnico" (id., ibid., p. 64), povos que desaparecem conheceram crises de autoinspiração e quebra no continuum da climatização etno-esférica. Como exemplo de povos bem-sucedidos, não há outro melhor que o povo de Javé, que segue integrado em uma aliança de mais de três mil anos. Já o exemplo dado por Sloterdijk de povos em dissolução que se convertem em meros bandos sem filhos é o dos azanda na África Central cuja população decresceu incrivelmente após a tomada do país pelos europeus. O suicídio dos jovens Yanomami no Brasil é outro exemplo de situação semelhante, a não ser que antropologicamente haja algum sentido intrínseco de afirmação do Yanomami no ato do suicídio.

Se os povos são conjuntos médios que implicam na síntese e na absorção de milhares de hordas, Sloterdijk formula a equação simples segundo a qual onde há um povo há também "céus de deuses conformadores de povo" (id., ibid., p. 63). Isso quer dizer que um deus é aí um nome para um conjunto de calibramentos atmosféricosimbólicos; ele é tanto uma culinária quanto um cheiro e um ritmo específico.

Dos pequenos clãs de uma centena de pessoas às casas do mundo de magnitudes médias (povos) até os grandes impérios, o que está em questão é sempre a esfera e o aumento do seu tamanho. Do ponto de vista esferológico e da criação de "mundos interiores", um clã de setenta pessoas é tão digno quanto um império de milhões. Se a morte amplia originariamente as esferas, pois os enlutados imaginam um espaço circundado por mortos e espíritos, "o estresse injetado nas sociedades pela inveja e o mal atuam como consolidador de primeira instância" (id., 2004a, p. 163). Nas sociedades mais arcaicas, a diferença topológica entre o interior e o exterior é 
imunologicamente ativa e relevante porque os grupos buscam sempre se defender do mal, e toda sua ritualística violenta visa afugentá-lo do interior do grupo. "Os grupos primitivos se consolidam como juramentações contra o mal e se aglutinam, por assim dizer, como equipes para sua exclusão e expulsão" (id., ibid.). Os grupos arcaicos são acampamentos circulares que buscam a afirmação constante do "interior" frente aos "perigos exoesféricos". O grupo santifica o espaço-dentro em oposição à zona exoesférica onde vagam os perturbadores e os expulsos. Essas considerações de Sloterdijk coincidem, grosso modo, como ele mesmo o indica, com a tese central de René Girard, segundo a qual os grupos humanos no começo nada mais são do que "sistemas de inveja e ciúme - ou rivalidade -, animados por imperativos de imitação" (id., ibid., p. 165). Isso gera um stress endógeno e os grupos elegem então um bode expiatório, uma vítima coletiva cujo assassinato restitui a tranquilidade do pós-stress. Segundo Girard, a solda, o princípio-síntese de uma cultura, ancora-se no hiperestímulo do linchamento. $\mathrm{O}$ bode expiatório é integrador porque é "a expulsão do mal o que torna possível a autoinclusão dos não-maus em um espaço-nós pateticamente ocupado" (id., ibid., p. 166). Não há assim como viver sem inimigos e vítimas, e o objeto sacrificial ocupa o cerne do grupo. Ele é o próprio bode expiatório que impera numinosa e inquietantemente, ao enredar e estabilizar de modo religioso o grupo. Ele é o deus que outorga "coerência étnica" (id., ibid., p. 168). A substituição das imunidades sacrificiais com a sua violência característica e o acúmulo de sangue por sistemas imunes, em que Deus aparece como um protetor comum cujo cuidado abarca o todo e que pede discrição e menos ações violentas por parte dos homens, começam no Egito Antigo e têm precedentes na Babilônia. ${ }^{39}$

\section{ADENDO II}

\section{Sobre a virada winnicottiana}

Se as filosofias do século XX dialogaram sobejamente com a psicanálise de Freud e Lacan, parece que uma das novidades do pensamento de Sloterdijk é substituí-

\footnotetext{
${ }^{39}$ Sloterdijk comenta o livro sapiencial do Antigo Egito (1300 a.C), no qual encontram-se "antecipados" não só o Antigo, mas também o Novo Testamento. Trata-se da doutrina de Amenemope para seu filho Kar-nakht. Esse tipo de tendência já se manifestava em 1700 a.C no código de Hamurabi.
} 
los como mestres em assunto antropológico por D. Winnicott. Tal substituição acarreta uma mudança de acento e uma virada de Stimmung, pois o tom trágico e agônico dos dois psicanalistas primeiramente mencionados dá lugar a um pensamento mais centrado nas figuras do amparo e da sustentação. A aliança com o autor inglês é compreensível também à luz da rejeição sloterdijkiana das antropologias da carência e da "síndrome pessimista" (id., 2009a, p. 531) do século XX. Nesse sentido, Winnicott não só aparece no lugar de Freud e Lacan, mas contra esses dois autores e outros como Gehlen, Schmitt e Adorno.

A questão central da psicanálise winnicottiana é a do florescimento do self por sustentação ambiental ou de sua aniquilação por falha nessa sustentação. As mães são pensadas como estufas criadoras do si mesmo dos bebês. Estes precisam do cuidado materno como se fossem fogareiros em que o verdadeiro si mesmo é cozido no fogo lento e brando das atenções e cuidados. A falta da presença da mãe ou uma mãe "morta" e deprimida, que não se relaciona com seu bebê, ou ainda uma mãe hiperpresente, mas que é insensível ao que é próprio do seu bebê, todas essas mães ou esses aliados, na linguagem de Slotertijk, são fortes candidatos a aniquilar o self incipiente. O analista winnicottiano ao invés de decifrar o inconsciente reprimido, usando a técnica freudiana e o seu talking-cure, será alguém capaz de, pelo cuidado ofertado, retomar o processo do vir-a-ser e do amadurecimento do seu paciente lá onde ele estancou. É ali onde estancou a continuidade, que surgem as organizações defensivas e as patologias. ${ }^{40}$ Por isso, muitas vezes o analista winnicottiano - que é alguém que se deixa usar ${ }^{41}$ pelas necessidades do paciente - vai regredir até lugares de experiência em que aquele ficou congelado por falta de acompanhamento e de cuidado.

A psicopatologia winnicottiana tem mais a ver com o não acontecido, que deveria ter acontecido, do que com a hermenêutica do que aconteceu e foi jogado para fora da consciência. É nesse sentido que Winnicott representa em psicanálise uma ruptura no paradigma interpretativo e uma transição para o do cuidado. ${ }^{42}$ Essa transformação implica também e na mesma medida uma mudança no setting analítico, o

\footnotetext{
${ }^{40}$ Sobre esse ponto cf. DIAS (2003) e WINNICOTT (2011).

${ }^{41}$ Adam Phillips, conhecedor profundo da obra de Winnicott, em seu livro intitulado Winnicott, escreve que o psicanalista inglês dizia que o analista "era como uma prostituta que estava ali para ser usado" (2006, p. 66).

${ }^{42}$ Grande parte das disputas teóricas na história da psicanálise mais recente versam sobre o que é continuidade e o que é ruptura na psicanálise winnicottiana. No Brasil, Loparic Zeljko, por exemplo, defende a tese de que Winnicott representa uma mudança de paradigma no sentido de Thomas Kuhn. Para Loparic, o paradigma edípico do bebê na cama com a mãe cede lugar ao paradigma do bebê no colo da mãe. Sobre isso cf. o artigo "Winnicott: uma psicanálise não-edipiana" (1997).
} 
que fica claro nos belos relatos de análise com Winnicott feitos por analistas, como é o caso de Harry Guntrip (2006), ou de pessoas que viriam a ser analistas, como Margaret Little (1992). Nesse último relato, verifica-se que Winnicott se permitia inclusive contatos físicos no holding da paciente, o que seria escandaloso para um analista freudiano ou lacaniano. Pode-se afirmar que, se o analisando freudiano deve se adaptar ao método psicanalítico de Freud, no caso do winnicottiano, é o analista que deve se adaptar ao seu paciente.

O tópico mais central das descobertas de Winnicott está na ideia de que no início não existe aquilo que se poderia denominar um bebê, mas sim um "casal-cuidador", pois ninguém jamais se depara com um bebê. "Se você vê um bebê, você certamente vê também alguém que cuida do bebê, ou, ao menos, um carrinho de bebê com os olhos e orelhas de alguém nele grudados. Vê-se um 'casal-cuidador"” (apud PHILLIPS, 2006, p. 27). Olhar para o entre desse dois-em-um foi a virtude principal de Winnicott. Ali onde seus antecessores enxergaram a pulsão e sua satisfação e a existência já suposta de um bebê "bocudo" e hedonista, Winnicott vê a busca do contato com uma pessoa e não a "gratificação instintual" de um objeto. Como explica Adam Phillips, "o bebê começa a vida como um ser profundamente sociável: ele clama por intimidade, não apenas pelo alívio da tensão - pela proximidade, não só pela satisfação” (PHILLIPS, 2006, p. 31).

No lugar da gratificação instintiva, ${ }^{43}$ buscada por um sujeito psíquico já em funcionamento, Winnicott vê no bebê o artista formativo de si em busca da aquisição de certos funcionamentos que ainda não existem. No caso winnicottiano, pode-se afirmar que o "cuidado de si" depende da sustentação do outro e, na falta deste, o bebê despenca nas agonias impensáveis. $\mathrm{O}$ bebê winnicottiano é vulnerável e sua imaturidade requer a presença do outro. No começo, nós dependemos radicalmente e toda independência é relativa e está vinculada ao reconhecimento da dependência. Essa fragilidade precoce do bebê é o cerne da psicanálise de Winnicott e não o complexo de Édipo de Freud.

Não há dúvida de que Sloterdijk concebeu a sua subjetividade consubjetiva do começo inspirado em Winnicott. Pode se afirmar que a microesferologia de Sloterdijk e a sua maneira de entender a antropogênese têm matriz winnicottiana. Paradoxalmente, e o paradoxo é um dos aspectos do pensamento de Winnicott, o desamparo do bebê não dá lugar a um pensamento trágico, mas a uma antropogênese feliz. E não há antropogênese feliz em Freud, Klein ou Lacan. Também as críticas de Sloterdijk a

\footnotetext{
${ }^{43}$ Em $O$ brincar e a realidade, Winnicott escreve que "não é a satisfação instintual que faz um bebê começar a ser, sentir que a vida é real, achar a vida digna de ser vivida" (WINNICOTT, 1975, p. 137).
} 
Freud e a Lacan coincidem, na maioria das vezes, com as de Winnicott, quer elas sejam feitas de próprio punho ou por seguidores como Masud Kahn e Adam Phillips.

Winnicott é citado explicitamente em $O$ estranhamento do mundo, livro essencial que precede a esferologia. Nessa obra de título emblemático, o filósofo alemão usa as expressões bad enough mother e holding. Esse título é revelador, pois após esse livro, Sloterdijk vai pensar o desestranhamento e os processos de enraizamento, intimização e familiarização com o mundo. Ora, uma mãe winicottiana é o ente propiciador desse desestranhamento do mundo. É a mãe ou o aliado complementador na linguagem sloterdijkiana que dota a criança de repertórios e de experiências cujo carregamento e transferência permitem que o si-mesmo não desabe nem se desmanche em situações de indiferença e hostilidade. O pensamento das migrações e das legalidades esferológicas também é devedor da questão winnicottiana da transicionalidade. Transicionalidade diz do uso que uma criança faz de algum objeto que a ajudará na transição da concretude do colo para a aquisição do mundo simbólico. Quando a mãe se ausenta, o bebê segura alguma fralda ou ursinho e esses objetos garantem a presença da mãe mesmo na sua ausência. Se a mãe retorna, então o bebê pode confiar nela e no objeto transicional. Se a mãe demora para voltar ou não volta, o ursinho perde o sentido e o bebê despenca no vazio. No abandono, o incipiente mundo interno se desfaz, mas se o aliado retorna e o

menino tiver conseguido a posse de seu objeto transicional enquanto ele espera a mãe voltar e enquanto ele espera surgir dentro dele um mundo simbólico, representacional, que possa garantir uma mãe "dentro" dele, ele estará a salvo e sua mãe também estará salva, para ele (MADUENHO, 2012, p. 38).

O objeto transicional é aquele que garante o início do povoamento do mundo "interior" da criança e a possibilidade da sua separação da mãe. A criança pode despedir-se da concretude-mãe, porque o que ela carrega dentro de si dessa mãe garante que não haverá uma ruptura e uma desconexão total. Uma desconexão total implica desabar no nada (agonias impensáveis). A perda da mãe, nesse momento, é a perda do mundo.

Não é temerário afirmar que Sloterdijk trouxe as mães winnicottianas da Londres pragmático-empírica para o interior da ontologia heideggeriana. Transformouas em aliados e mostrou que os duros ontólogos inteligentes e angustiados nada saberão do mundo e do chegar ao mundo se não entenderem de confiança, ressonância e aliança. 
Mostrou também que, se os filósofos não se abrirem para a puericultura, não poderão filosofar corretamente, pois esperarão mais (ou menos) do que a natureza humana pode dar. Pode-se dizer, grosso modo, que um pensamento como o de Winnicott, de transições e migrações por múltiplas regiões da experiência e "sentidos do ser" (objetos subjetivos, objetos transicionais e realidade exterior), pode ser traduzido em termos de destino esferológico e inversamente, um pensamento esferológico, que versa sobre o aumento, a catástrofe e o destino das esferas, pode ser traduzido em termos das passagens desde o objeto subjetivo e a imersão na mãe até o grande mundo partilhado. Na epígrafe de Tudo começa em casa (WINNICOTT, 2011), obra póstuma que reúne palestras de Winnicott, o poema "East Coker", de Four Quartets, de Eliot, diz:

O lar é nosso ponto de partida. À medida que crescemos O mundo se torna mais estranho, mais complexos os padrões De morrer e viver. Não o momento intenso Isolado, sem antes nem depois.

Mas uma vida ardendo em cada momento.

Encontra-se aqui o inteiro escopo da esferologia: a crítica à intensidade descontínua e a ideia de que o si mesmo não precisa aferrar-se a si vigilantemente, mas que ele pode se prolongar e ficar contido em outros que não o falsificam. Isso significa que o homem não se perde de si ao migrar dos mundos pequenos para os grandes e para as instituições. Parte de outra epígrafe, escolhida por Adam Phillips para o seu livro Winnicott, sintetiza genialmente essa situação: “A primeira lição que a inocente infância me proporciona é - ser um instinto de minha natureza para me desligar de mim mesmo e me perpetuar em forma de outros" (S. T. Coleridge).

O que pode soar estranho é o fato de que Sloterdijk, um autor bastante generoso ao citar suas fontes, não cite muitas vezes Donald Winnicott em Esferas I. Mas essa impressão logo se desfaz se atentarmos para o uso repetido de expressões que são marcas registradas winnicottianas como "a mãe suficientemente boa" (SLOTERDIJK, 2003, p. 50 e 400-401), “a saudação suficientemente boa” (id., ibid., p. 460). De qualquer modo, é evidente que partir da mãe como a situação do filho e da situação do filho como "incorporada" na da mãe (id., ibid., p. 461) equivale a partir do paradigma winnicottiano. Mas Sloterdijk, longe de ser um terapeuta desta linhagem, parte dessa situação consubjetiva para pensar o espaço e a ideia fundamental de receptáculo imunológico como arranjo contra a exterioridade. Vale dizer que o pediatra inglês fornece as bases para que Sloterdijk avance em relação à análise heideggeriana do 
espaço, à culturologia morfológica de Spengler e à ideia de estufas de Arnold Gehlen. A microesferologia não pretende competir com a riqueza de detalhes da teoria do amadurecimento de Winnicott. Ela é a base para um pensamento das arquiteturas imunológicas historiais, o que equivale a recontar a história humana e a das culturas a partir da noção de holding (sustentação) e das mudanças na forma dessa sustentação. ${ }^{44}$

Nesse sentido, pode-se dizer que uma apropriação pensante de Winnicott é responsável por boa parte da renovação da filosofia alemã e europeia. Um ponto decisivo nesse quesito é o abandono por parte de Sloterdijk da categoria de alienação. Winnicott é um aliado nessa questão, pois, para ele, nem o chegar a si mesmo é resultado de uma alienação originária nem a entrada no mundo é uma submissão ao já dado. Para Winnicott, o "eu" não é lugar de alienação, e o ponto de partida não é a experiência de um corpo despedaçado ${ }^{45}$ que se estrutura em uma imagem. A essência do ser humano só estaria alienada e o mundo mortificado se o bebê não criasse o que ele encontra. Winnicott presume que "existe uma criatividade potencial, e que na primeira mamada teórica o bebê tem sim uma contribuição pessoal a fazer" (WINNICOTT, 1990, p. 130). Cada ser humano que nasce recria o mundo. Já não é preciso acender cem velas para as coisas obscuras, nem buscar estratégias de fuga de um mundo consumado. Há sempre um barro, uma indeterminação, e aqueles que chegam ao mundo, não sabemos por onde passarão os seus gestos e por meio de que atos e apropriações eles ganharão ser. A passagem do exterior ao interior animado é o gesto criativo. Nesse sentido, o mundo começa sob o signo da criação e não da alienação! Como escreve Winnicott: "Sabemos que o mundo estava lá antes do bebê, mas o bebê não sabe disso, e no início tem a ilusão de que o que ele encontra foi por ele criado" (id., ibid., p. 131), como o menino e a bolha de sabão na abertura de Esferas $I$.

A mudança de Stimmung do pensamento sloterdijkiano tem suas raízes no fato de ele ter colocado o assunto do nascimento como tema central do pensar. Pode-se dizer que essa operação inédita em filosofia tem também, embora não unicamente, raízes winnicottianas. A obsessão pela questão do nascimento e do chegar ao mundo, bem

\footnotetext{
${ }^{44}$ É interessante notar que Winnicott parece ter enunciado em $O$ brincar e a realidade, publicado originalmente em 1971, um projeto que a esferologia de Sloterdijk realizou: "Dependemos aqui de algum método de registro. Sem dúvida, muito se perdeu das primeiras civilizações, mas, nos mitos, que foram produto da tradição oral, é possível perceber a existência de um fundo cultural, estendendo-se por seis mil anos, e fazendo a história da cultural humana" (WINNICOTT, 1975, p. 138).

${ }^{45}$ Para Winnicott, o ponto de partida é a não integração. "No início, antes que cada indivíduo crie o mundo novamente, existe um simples estado de ser, e uma consciência (awareness) incipiente da continuidade do ser e da continuidade de existir no tempo. [...] A não integração, o estado primário, não é caótico" (WINNICOTTI, 1990, p. 157).
} 
como as dificuldades dessa chegada encarnadas na tradição gnóstica, tirou Sloterdijk do páthos dominante no ambiente "apocalíptico ou mais pós-apocalíptico [...] fundado na antiga Teoria Crítica que afirmava que o mundo capitalista era um fim de mundo permanente" (SLOTERDIJK, 1999c, p. 95). Para Sloterdijk, o nascimento aparece como questão essencial já muito antes do projeto Esferas. Há na sua obra uma passagem da antropologia cinética para a esferologia. A ideia do homem como animal migrante e de experiência permanece, mas a esferologia permite pensar os caminhos dessa experiência no interior do mundo com maior radicalidade do que as obras anteriores, que se encontram mais sob o signo de Nietzsche e Heidegger, isto é, mais voltadas à luta para vir ao mundo e à irrupção originária nele. A antropologia cinética - analítica do vir ao mundo - não consegue tematizar e explicitar a experiência estabilizada do homem já enraizado no mundo pela mediação do sistema imune não técnico chamado mãe. Há, portanto, uma transição muito clara das obras do “jovem Sloterdijk” para o projeto Esferas. Essa transição pode ser nomeada de virada ou de aprofundamento winnicottiano. Tal virada aumenta o âmbito da transicionalidade e permite ir mais fundo no mundo, deixando de analisar apenas as suas bordas iniciais. O páthos winnicottiano da confiança no mundo e do mergulho criativo e afirmativo nele, muito diferente do sim genérico e quase especulativo de Nietzsche, ${ }^{46}$ representa um claro afastamento tanto das buscas de Nietzsche, o "buscador fracassado de um lugar suportável para ele no mundo" (id., 2009a, p. 411), quanto da gnose negadora de Adorno e também da dificuldade heideggeriana de pensar o enraizamento. $O$ aprofundamento winnicottiano e a introdução do nascimento e das mães ${ }^{47}$ na filosofia permitem a Sloterdijk reposicionar suas principais matrizes e filiações intelectuais.

Se Vir ao mundo vir à linguagem (1988) e A mobilização infinita (1989) pensam a poética do parto e os dramas do chegar ao mundo sem a introdução da categoria do anfitrião aliado, O estranhamento do mundo (1993) e Autoinvestigação: uma conversa com Carlos Oliveira (1996), ainda que já anunciem as Esferas, não pensam ainda as migrações "dentro" do mundo e as culturas como habitáculos que sucedem corpos

\footnotetext{
${ }^{46}$ Abordo esferologicamente a luta nietzscheana para nascer em "Ensaio de filosofia fisionômica", publicado na revista winnicottiana Natureza Humana (PESSANHA, 2014, p. 141-148). Do ponto de vista desenvolvido neste ensaio, pode-se afirmar que importam mais os pequenos sins concretos e incorporadores do que um grande sim não especificado.

47 'No contexto esferológico [...], 'mãe' é - recordemos - o sinônimo mais poderoso da imunidade não técnica, com respeito ao qual é preciso ter em conta que a mecanização da maternidade representa o programa manifesto da civilização pós-teológica" (SLOTERDIJK, 2004a, p. 94).
} 
maternos. O primeiro desses dois últimos livros, inclusive, detém-se nas experiências de negação do mundo. ${ }^{48}$

O que se chamou há pouco de aprofundamento winnicottiano no pensamento de Sloterdijk vai tão longe a ponto de ele afirmar na longa entrevista de 2007, O sol e a morte, que a própria modernidade é uma tentativa de substituir a intimidade materna por procedimentos técnicos. “A mãe, a biomecenas, é substituída por um sistema artificial de mecenato" (id., 2007, p. 174). Dado que a maternidade é um bem escasso, "constantemente ameaçado pelo cansaço, pela impaciência, pela experiência de carência" (id., ibid.), há um interesse imenso em trocar os mecenas primários (mães) por secundários (deuses, aparelhos e sistemas de solidariedade). Se a isso se acrescenta a informação de que a grande maioria dos assassinatos de crianças é praticada pelas próprias mães nas mais variadas culturas, não haverá dificuldade de entender o movimento "matrífugo" ou de fuga da mãe na direção do artificial. Sloterdijk toma na entrevista citada o conceito de mecenato de Dieter Claessens, autor de Das Konkrete und das Abstrakte. Soziologische Skizzen zur Anthropologie, de 1988, e vai na direção de uma teoria das substituições. Se Deus é o título para um primeiro mecenas secundário, a sua principal clientela é a de meninos abandonados e descuidados que sobrevivem. Se como ensina Esferas I, o juízo final na verdade está no início, na canção de boas-vindas entoadas pelas mães e na festa do evangelho do nome da criança, então o juízo final do fim é uma invenção dos meninos do buraco negro do desamparo. Para Sloterdijk, o menino sem boas-vindas é o verdadeiro destinatário "da religião da redenção e dos seus sucessores modernos, as filosofias da redenção e da reconciliação, com a sua terapêutica correspondente" (id., ibid.). Certamente muitos ficarão indignados com a hipótese de que um receptor animado de ideias soteriológicas, sejam elas sagradas sejam elas laicas, é alguém que na verdade deve buscar uma "mãe suficientemente boa" em um consultório winnicottiano ou um guru para problemas existenciais. Resta saber se o indignado diante desta hipótese de Sloterdijk é ele próprio um "menino problema" ou se a tese do filósofo segundo a qual nas condições da modernidade atual (palácio de $\operatorname{cristal}^{49}$ ) já não há mais salvação nem relação com uma totalidade que pudesse ser ultrapassada - pois vivemos em espumas numa sociedade hiperdiferenciada em subsistemas - é uma tese aceitável ou não. Se Sloterdijk estiver certo no seu diagnóstico epocal, todo "revolucionário" deveria buscar um consultório

\footnotetext{
${ }^{48}$ As datas entre parênteses correspondem às publicações originais na Alemanha.

${ }^{49}$ No capítulo 4, parte 2, analisaremos mais detidamente a questão do palácio de cristal.
} 
para acertar as contas com o mundo pós-histórico e encaminhar-se para o guichê das espumas animadoras especializadas em subculturas rebeldes.

\subsection{O design metafísico e sua crise}

Se Esferas I começava com a descrição da imagem do menino e da bolha de sabão na tela de um pintor inglês, Esferas II começa com a reconstrução da tertúlia filosófica entre os sete sábios no mosaico da Torre Annunziata. Os sete pensadores encontram-se extasiados diante do imenso e da contemplação da sphaira. O páthos da vidência teórica e argumentativa supera o assombro trágico do teatro dionisíaco. $\mathrm{O}$ resultado da investigação dos sete é a reverência diante do uno e do completo. Uma tal atitude frente ao que é pede línguas lógicas, e é um sábio aquele que consegue visualizar a "suprema ideia de espaço" (SLOTERDIJK, 2004a, p. 22). Sábio é aquele que tem diante de si uma esfera. A sua contemplação integra o sábio na região da serenidade. Representar uma esfera é ter acesso à totalidade do que existe e ao seu fundamento perfeito: Deus. Deus é agora o absoluto, o englobante máximo, e aquele que o contempla também participa localmente do "optimun global" (id., ibid., p. 25): está incluído no anel do ser. Eíso pánta (tudo está dentro). O intelecto comovido maravilhase por pertencer a uma dimensão salvífica. A forma da esfera como um abrigo geométrico contém o sábio que não pode deixar de estar entusiasmado. Alguém não entusiasmado é simplesmente alguém que "não entendeu onde está com relação a si mesmo e ao todo" (id., ibid., p. 26).

Sloteredijk mostra que a globalização começa "como geometrização do incomensurável” (id., ibid., p. 43). Essa esferopoiésis do imenso e do máximo é o "acontecimento fundamental do pensamento europeu" (id., ibid., p. 44). A globalização matemático-geométrica oferece uma forma a partir da qual posso explicar a totalidade do ente. Em termos da analítica existencial do onde, desde que o espaço tomou a forma da esfera,

os seres humanos podem e devem se localizar em um envolvente, o periéchon, que já não é um seio ou uma gruta vegetativa, um lar ou uma comunidade de culto, que se comove em um coro de baile, mas uma forma de construção, lógica e cosmológica, de validade atemporal (id., ibid., p. 46). 
Como há um centro desta esfera, a questão é saber onde estamos em relação a ele. Perto ou longe? Familiarizados com ele ou divorciados? Desde Parmênides, o pensador inaugural europeu da unidade do todo - o redondo perfeito -, aquilo que Sloterdijk chama de projeto Alma-do-Mundo se converte num padrão para medir a imperfeição do mundo empírico.

O desenho da esfera é um acontecimento fundamental e contar o seu destino desde o início grego é recontar a história ocidental, pois ela vai se converter no globo imperial dos romanos e também dos cristãos até chegar ao globo de hoje, atravessado e percorrido pelo movimento incessante do dinheiro. Quem é o senhor da esfera? Os imperadores, o cosmocrata Cristo, os cientistas a esquadrinhar o globo terrestre após o colapso da esfera metafísica ou as empresas transnacionais? Como se vê, recapitular essa história é contar a nós mesmos a história política dos últimos 2500 anos. Esferas II pode ser lido assim como uma poderosa intervenção nos debates ocorridos entre os anos 1990 a meados de 2000 sobre a globalização e os seus efeitos. Enquanto jornais e revistas, bem como livros de ciências humanas, pretendiam anunciar o último grito sobre a globalização, Sloterdijk mostra que a história da globalização retrocedia, na verdade, à racionalização do universo na imagem da esfera pelos gregos. Isso implica um descolamento da atualidade jornalística para a tarefa hercúlea de recapitular as metamorfoses da esfera até que ela se torne apenas o nosso globo terrestre (sem o outro globo celestial metafísico ${ }^{50}$ ), a superfície rugosa do astro, onde se passou a viver sem mais se remeter para aquele do alto. Esferas II percorre, portanto, o longo caminho que vem desde o instante parmenídico à conquista da terra pelos europeus.

O que Sloterdijk chama de "instante de Parmênides" é o próprio abrir-se do espaço filosófico como a "imensidão iluminada" (id., ibid., p. 78). O uno-todo não é algo que se veja de fora ou de uma exterioridade. Não. A esfera absoluta

se oferece já, também, desde dentro, irremissivelmente e para sempre, à inteligência que olha ao redor. Esta visão sincrônica, panóptica, ao interior do uno-todo, que vibra em si mesmo como um recipienteesfera-iluminado, é a que reclama a deusa como a única visão verdadeira (id., ibid., p. 79).

Não se olha para o todo como para algo simplesmente em frente ou aí diante. Sloterdijk diz que essa grande visão intuitiva no interior do uno é um "valor limite

\footnotetext{
${ }^{50}$ Sloterdijk no início de Esferas II (p. 69-72) esclarece que foi apenas a partir de 1830 que se deixou de fabricar o globo terrestre e o celeste conjuntamente. Nós, modernos, já nem lembramos disso, filhos que somos da imanência e do abandono do céu fictício.
} 
extático da concepção natural do mundo surgida da situação fundamental característica do ser-no-mundo (id., ibid.). Esse acesso à visão totalizante no interior do ser, ${ }^{51}$ a deusa o concede ao filósofo e não ao vulgo distraído e concernido apenas pelas circunstâncias e opiniões. Os mortais comuns, ainda que estejam no interior da esfera, não têm olhos para ela.

A discussão sloterdijkiana da ontologia de Parmênides esclarece a diferença entre um olhar excêntrico que olha de fora para um universo dado, do olhar extáticopanorâmico, ele mesmo abarcado e "rodeado de plenitude imóvel, íntegra" (id., ibid., p. 83). A participação no interior do que é superlativamente esclarece o concentrismoextático-panorâmico. Nessa posição - endoteológica - Deus ocupa o centro do ser e a inspeção na esfera-todo acontece a partir de dentro. A outra posição que o filósofo alemão denomina de "excentrismo-metafísico-globalizante" (id., ibid.) é exoteológica, pois nela Deus estaria localizado diante da totalidade dos entes. ${ }^{52}$ É a primeira situação que interessa, pois, no interior do design hiperimunológico metafísico, a questão principal é a da relação dos homens, seres deslocados e removidos do centro com o centro divino. Já no caso de Parmênides, a visão da esfera permanentemente imóvel do “que é” só é acessível ao filósofo favorecido pela deusa. A posição central extáticopanorâmica de imersão clarividente no grande único não é partilhada por todos. A grande maioria tem os olhos turvos, erra pelas opiniões e está localizada em pontos epicêntricos. Os humanos na era metafísica são os "marginais de Deus" (id., ibid., p. 90), os que estão distantes do ponto central. Esse é o momento no qual Sloterdijk recupera todas as análises microesferológicas, pois a relação estabelecida entre a existência epicêntrica humana e o centro doador é uma relação forte do mesmo tipo das existentes no campo íntimo inter-humano. Os seres humanos da era metafísica são os epicêntricos e

estão subordinados a um centro e são utilizados e atraídos por ele. Os protótipos mais claros de tais utilizações íntimas de seres humanos como portadores do absoluto se encontram na história da salvação cristã [...]. Enquanto pretende estender a salvação, a práxis cristã

\footnotetext{
51 "Nem divisível é, pois é todo idêntico; / nem algo em uma parte mais, que o impedisse de conter-se,/ nem também algo menos, mas é cheio do que é, / por isso é todo contínuo; pois ente a ente adere //[...] Então, pois limite é extremo, bem terminado é/ de todo lado, semelhante a volume de esfera bem redonda, do centro equilibrado em tudo; pois ele nem algo maior / nem algo menor é necessário ser aqui ou ali." (PARMÊNIDES, 1978, p. 143).

52 Sloterdijk discute essa posição ao analisar a figura do Atlas Farnésio, que carrega o globo nas costas. Não se vai aqui recapitular essa posição ingênua na medida em que ela diz pouco em relação ao cerne do paradigma metafísico, que é, precisamente, a relação dos seres humanos epicêntricos com o centro divino.
} 
inteira é teofórica, isto é, está fundada na sustentação do absoluto por forças finitas (id., ibid., p. 92).

O paradigma metafísico implica sempre a esfera animada e a existência cúmplice entre o ponto e o centro. $\mathrm{O}$ ponto trabalha espontaneamente a serviço do centro. Com o advento do cristianismo, a situação não é mais apenas a de um grande espaço esférico entorno, mas que esse envolvente universal é agora também o "emblema da relação forte entre ser humano e o ponto central" (id., ibid., p. 102). Afinal, o que é o cristianismo senão uma acomodação bíblica ao modelo prévio da metafísica da esfera?

Se Heidegger via a história do ocidente como a história das metamorfoses do ser e Nietzsche como a da consumação do niilismo, Sloterdijk pretende ler essa mesma história ocidental como sendo aquela das metamorfoses da esfera. E o que é a esfera senão uma superimunidade? E quem são os filósofos e os teólogos senão artífices e agentes de projetos imunizadores? Sloterdijk acredita que quem adentra seriamente nos "arquivos do uno" (id., ibid., p. 106) reconhece que a ultrapassada metafísica da velha Europa não foi mais que "uma teoria ritual imensamente circunstancial e complexa em honra de Sua Majestade a forma redonda" (id., ibid.). Se em Esferas I o par mãe-filho adentra um espaço interior de sustentação, agora são os metafísicos que buscam o mesmo objetivo imunológico ao desenhar a forma do universo como casa do ser. Tratase, mais uma vez, de desmentir a exterioridade em espaços inclusivos. No caso do metafísico, a tarefa é desenhar um hiperespaço amigável e os designers de monosferas gigantes têm o trabalho de

apaziguar a inquietude humana em um mundo ampliado abismalmente, aberto perigosamente, por meio da iniciação na forma mais edificante, mais envolvente, de imunidade: o universo; literalmente: o que abarca tudo em um único giro. A boa nova do evangelho do ser na redondeza do orbe reza: qualquer ponto do universo, por mais distante que esteja do centro, e embora fosse minha própria existência tremendo de desamparo, é alcançado e possibilitado, potencial e atualmente, por um raio que emana do centro (id., ibid., p. 106).

O tudo está dentro plotiniano é a fórmula imunológica para esta poderosa inclusividade. Se o centro atrai e acolhe a totalidade do ente, então não há nada realmente fora. Não há exterioridade e o centro e os epicentros vivem em relações 
animadas como em uma "assembleia vibrante" (id., ibid., p. 107) e cada indivíduo pode e deve encontrar sua participação no todo.

Para criticar a tese sloterdijkiana do design metafísico, seria necessário questionar as centenas de páginas que ele dedica ao estudo de Platão, Aristóteles, Plotino, Agostinho e Nicolau de Cusa em Esferas II. É óbvio que muitas dessas leituras poderão parecer problemáticas ao especialista ou filósofo profissional, mas, nesse caso, como no de Hegel, Heidegger ou Nietzsche, é preciso lembrar que as eventuais deformações estão ligadas ao movimento eminentemente filosófico da apropriação pensante. Nesse movimento, as filosofias anteriores são desestabilizadas e retiradas do relativo consenso dos comentaristas para serem iluminadas por uma chave nova. Essa nova chave, no caso sloterdijkiano, é a abordagem imunológica. Imunologicamente, sentenças como a de Agostinho - "Nosso coração está inquieto até que descanse em ti" - serão lidas sempre em termos do diálogo cooperativo entre centro e epicentro. Afinal, o que é uma grande filosofia, senão um novo olhar e uma nova senha para a história acontecida desta? Uma senha capaz de trazer uma nova compreensão da atualidade? E não é missão da filosofia entregar a nós, contemporâneos, uma bússola confiável que diga onde estamos? E qual filósofo pode hoje, num tempo de papers, hiperinstitucionalização e requentamentos contínuos de tradições esgotadas, dar uma visão clara do nosso onde?

Segundo a narrativa esferológica, toda a imunização cristã é tributária já da morfologia prévia da esfera, e Cristo "salva como já salvava a esfera" (id., ibid., p. 109). A esfera é salvífica, porque o redondo salva da exterioridade, e isso, traduzido para o contexto cristão, significa que tanto as almas quanto Deus pertencem ao mesmo Interior comum. Excêntricos radicais seriam apenas "Satã e os grandes pecadores" (id., ibid., p. 110) e, no âmbito filosófico, os atomistas e materialistas gregos que concebiam a possibilidade de um "vazio infinito sem centro" (id., ibid.). A afirmação ateia da exterioridade soava escandalosa, porque desprezava a proteção esférica e, ao legitimar uma existência excêntrica, rompia com a relação forte e necessária entre centro divino e epicentro humano. Posições como a de Satã ou dos materialistas antigos são modernas avant la lettre, pois é moderno aquele que já não tem salvação, mas sim "êxitos ou fracassos em jogos autorreferenciais entre pontos excêntricos” (id., ibid., p. 111). O não viver mais em uma assembleia comum vivificada pelo centro doador é viver modernamente no tráfego generalizado das comunicações. Para o Homo Metaphysicus, quem vive na eleição de si como o ponto referencial mais importante vive em mundos 
infernais. "O ser-na-esfera tinha precisamente o sentido de desprender os pontosindivíduos de sua autorreferência egoísta e, em uma grande extraversão ontológica e moral, remetê-los ao centro comum a todos" (id., ibid.). Nesse sentido, teocentrismo e altruísmo se correspondem, pois, no interior do desenho metafísico, as inteligências finitas são solidárias: elas se sabem como não centrais.

No mundo hiperinclusivo dos metafísicos, entende-se que os modelos cosmológicos sempre pusessem a terra no miolo central protegido por calotas superpostas "envolvidas todas elas por um firmamento extremo, o céu das estrelas fixas, que, por sua vez, só era superado pela morada dos bem-aventurados em Deus" (id., ibid., p. 114). Para além da mera compreensão dos textos aristotélicos, esse tipo de visão cosmológica só se deixa apreender radicalmente quando se nota a exigência morfológica de impermeabilização. Mais uma vez é a abordagem imunológica que desvenda o segredo da forma cosmológica. "A cosmologia das coberturas sela com meios físicos o pacto entre o centro e o universo dos pontos: mostra, com uma evidência quase insolente, o que significa querer ser e permanecer sob qualquer circunstância em um mundo interior" (id., ibid.).

O sistema de calotas de cobertura foi transmitido para toda a tradição metafísica a partir dos seus formuladores máximos, Platão e Aristóteles. A Idade Média acolheu esta herança e levou ao limite "os delírios das coberturas e encerou a terra, e as almas humanas sobre ela, em numerosos extratos de abóbodas celestes mais ou menos compactas" (id., ibid.). O que salta aos olhos é o esforço para blindar os seres humanos de qualquer assalto de infinitude, nada e exterioridade. A imunidade-deus assegura precisamente uma fronteira clara entre o dentro e o fora. Estar dentro da esfera é estar amparado. Ainda que a esfera na qual o homem metafísico está imerso seja imensa, essa imensidão é finita. Foi a infinitização de Deus pelos teólogos que conduziu endogenamente ao colapso da metafísica. Nesse sentido, a metafísica não precisa de desconstrução, pois ela própria, essa formação delirante de mais de 2 mil anos, acabou ao trazer a devastação do infinito para dentro de si.

O infinito destrói a esfera e sua provisão de imunidade. Se Deus é infinitizado, ele "se converte em algo invisível, obscuro, des-semelhante, amorfo: um monstro para a capacidade intuitiva humana, um não-receptáculo, um abismo e buraco absoluto" (id., ibid., p. 117). A morte de Deus é uma tragédia morfológica, pois a infinitização suprime a diferença entre estar dentro e estar fora. Anulada essa diferença, a ideia de que o todo do ente esteja envolvido numa grande alma desaparece. Não há mais nenhum ganho em 
estar dentro do infinito. $\mathrm{O}$ estar dentro requer a finitude. A infinitização de Deus e da esfera conduz inevitavelmente ao tema central da modernidade, que é a autorreferência dos pontos.

Com a morte da esfera inclusiva, os antigos epicentros ficam soltos e descentrados. A filosofia, embora tente abandonar o vocabulário da monoesfera, e passe a adotar a semântica do acontecimento, ainda permanece aos olhos de Sloterdijk vinculada ao infinitismo: noções como de comentário, diálogo, criatividade ou libido ligadas ao pós-estruturalismo francês ainda estão marcadas pelo "furor infinitista" (id., ibid., p. 121). O que é necessário é trabalhar "em uma ontologia do mundo finito, inacabado, imenso, no qual é preciso compensar, em seus radicalismos, momentos conservadores e explosivos, ou, como também se poderia dizer, interesses psíquicos e técnicos" (id., ibid.). A catástrofe do projeto metafísico alma do mundo não pode conduzir a uma desanimação total: o anímico e o psíquico precisam continuar existindo de algum modo. Se a animação (Beseelung) se esfria por falta do inspirador, o indivíduo isolado já não se cura do catarro ontológico: como pontos depressivos sem expansão, extensão nem participação passarão a vida "olhando absortos para fora, através da janela dos media, movidos a paisagens de imagens [...] imagens mais vivas que a maioria dos seus contempladores" (id, 2003, p. 76). Esse é um dos riscos da vida moderna nas espumas, tema do capítulo 3 desta tese.

A transição da superimunidade metafísica para a imunidade moderna significa o abandono do regime holístico aos quais se entregam os indivíduos numa espécie de "pan-simbiose" (id., 2009a, p. 186) com um todo amigável para um regime no qual a vida, a natureza e a sociedade são vistos como "protótipos de unidades de automanutenção, polemicamente delimitadoras, que reciprocamente se convertem em "entorno"” (id., ibid., p. 189). Esse tipo de situação, entretanto, só passa a vigorar plenamente a partir da ruptura histórica dos anos 20 do século XX. Foi só aí que a ontologia fria, "modernizada como teoria da imunidade e do entorno pôde conseguir plausibilidade intelectual" (id., ibid.). Antes disso, o motivo "alma do mundo" conviveu com o da mecanização muitas vezes numa mesma pessoa, como é o caso de Isaac Newton. Por causa desse convívio entre o mundo maquínico e a reanimação do panpsiquismo antigo, Sloterdijk desconfia do conceito de "desencantamento do mundo". Na verdade, o holismo clássico só caiu de vez quando a investigação científica em biologia revelou uma 
dimensão interorganísmica pré-pessoal diante da qual o holismo moral clássico caminha no vazio. Na medida em que um sistema de imunidade somático representa um mecanismo de defesa antimicrobiano, este e seu proprietário, o indivíduo, "participam" de uma defensiva inocente [...]. Pertence tanto à natureza como à virtude de um sistema capaz de automanutenção poder se defender de seus invasores e competidores pelo domínio do mesmo espaço biológico, sobretudo quando se esgotam as alternativas simbióticas (id., ibid., p. 190).

O fim do holismo metafísico abre o caminho para uma nova situação na qual já não nos encontramos no interior de um todo omnicomunicante, mas no de cápsulas autorreferentes e autoasseguradoras, que estão isoladas e conectadas. ${ }^{53}$ Esferas III, obra que será abordada mais detidamente no capítulo seguinte desta tese, analisará essa nova situação de multiplicidade dos sistemas sociais modernos em cujo regime nós vivemos hoje.

${ }^{53} \mathrm{O}$ termo connected isolation (isolamento conectado) é tomado por Sloterdijk do grupo de arquitetos americanos Morphosis, Thom Mayne e Michel Rotondi (SLOTERDIJK, 2009a, p. 197). 
3. ANALÍTICA DAS ESPUMAS 


\subsection{Explicitação crescente e ontologia da atualidade}

No terceiro volume da trilogia, Sloterdijk faz uma análise da era presente; uma ontologia da atualidade. Ser-nas-espumas é viver em um mundo amorfo e descentrado, no qual já não há mais uma integração da multiplicidade espumosa em um hiperglobo unificador. O colapso da hiperesfera ou morte de Deus coloca de forma nova a questão das criações de contexto e de formação de mundo interior. É agora o próprio homem que desenhará tecnicamente as arquiteturas de imunidade.

Quem diz modernidade diz que o homem já não está ingenuamente no mundoda-vida (Lebenswelt), mas que o mundo-da-vida, após ter sido tematizado e explicitado, dá lugar a um mundo tecnicamente instalado; então é moderno aquele homem cuja imersão se dá em espacialidades e situações que ele mesmo desenha segundo seus “próprios planos e avaliações” (SLOTERDIJK, 2009a, p. 58).

A revolução da explicitação é a morte da ingenuidade e da inocência. Que se tome o exemplo dos anatomistas: lá onde o corpo era opaco e trancado em obscuridades inacessíveis, ele aparece agora visível e nítido. Após o corte dos anatomistas, a luz da investigação tira do Léthê o interior oculto dos órgãos e o divulga publicamente.

Esse trazer à luz o até então oculto é o traço central da modernidade. O que vem à luz, recebendo cidadania no claro, não são mais as velhas "aparições naturais" que se auto-ofereciam ao olho humano numa fenomenalidade básica, mas coisas forçadas à visibilidade por meio de máquinas e apetrechos. O mundo invisível é forçado a comparecer e a mostrar-se por meio da operação de olhos mecânicos e sensores. Diante desses novos fenômenos, o olho antigo é aposentado, pois partículas atômicas, tomografias, cérebros e sistemas imunológicos são realidades de segunda ordem, completamente inacessíveis ao velho olho. Aquilo que é forçado a surgir pela mediação de máquinas, como a biomecânica do "próprio corpo" ou o próprio cérebro, aparece como "realidades" estranhas, radicalmente exteriores e não próprias. Aparece como um saber fora da subjetividade.

É a era da técnica e da presentificação tecnológica-artificial. A técnica pensada heideggerianamente como um modo específico de desocultar os entes implica a caducidade do movimento fenomenológico do "ir às coisas mesmas" e salvá-las. A fenomenologia aparece como uma reação ao domínio técnico, ela "é uma restauração 
positiva da percepção, após seu ultrapassamento pela observação mecânica" (id., ibid., p. 67).

O século XX é aquele da explicação e da explicitação. Ele elucidou as atmosferas existenciais, as relações formadoras do bebê com a mãe e os confins da matéria viva. Ele abriu a caixa preta das culturas e devassou analiticamente a própria antropogênese. Para Sloterdijk, o século XX não é a época das revoluções sociais, pois "o de cima e o de baixo não mudaram de lugar [...], em vão buscar-se-ia um comprovante de que os últimos se tornaram [...] os primeiros" (id., ibid., p. 71). O que efetivamente atravessa o século XX e o caracteriza em sua essência é que, por toda a parte e em todas as frentes, se obrigou a manifestação do latente e o antes velado, forçado a aparecer, tornou-se disponível e operativo. "O que se pode explorar [...], investigar mediante perfurações de profundidade, intervenções e hipóteses invasivas, chegou aos depósitos de combustíveis, ao texto impresso, ao balanço de negócios" (id., ibid.).

O evento central e paradigmático do século XX é a explicitação da atmosfera. Nesse século, o antigo e ingênuo ser-aí no ar foi ultrapassado tanto pela gaseificação do ambiente na guerra química quanto pela radiatividade tornada explícita na guerra nuclear. A introdução do meio ambiente na luta entre os adversários fez submergir a existência do homem em meios "invivíveis". Aprendeu-se o que é ser-no-irrespirável, ser-no-fogo, e ser-no-invivível. Superou-se o combate homem a homem e o combate de fuzil pelos ataques ao meio ambiente. O homem tornou-se designer de atmosferas vivíveis e invivíveis, como é o caso da diferença entre estar-dentro de uma câmara de gás e estar fora dela.

A famosa apatridade (Heimatlösigkeit), que Heidegger viu como o traço essencial da época da armação (Ge-stell Zeitalter), significa para Sloterdijk não só a “desnaturalização do ser humano do envoltório natural do ar e sua mudança a espaços climatizados", mas também e, principalmente, a apatridade "simboliza o êxodo de todos os possíveis nichos de proteção na latência" (id., ibid., p. 116). O ser-aí do nosso tempo já é o migrante do ser-no-mundo 1 para o ser-no-mundo reconstruído 2, conforme o paradigma da astronáutica tripulada e sua instalação de ilhas ambientais no invivível. Após a exploração da latência, como encontrar um lugar ainda escuro e imune às explicações; um lugar-quadrindade (Geviert), onde entes como vírus e partículas não tivessem cidadania? Para Sloterdijk, um lugar assim, próximo do "frio vento do exterior" (id., ibid., p. 117) teria de ser ele mesmo, paradoxalmente, produzido pela 
engenharia política e concedido não pelo ser, mas pela "produção técnica e assessoramento jurídico" (id., ibid., p. 118). Vale dizer que o pastor do ser, guardião dolorido do exílio, teria de estar imunizado juridicamente e gozar de alguma bolsa existência.

Do mesmo modo que, após a explicação do inconsciente pela psicanálise freudiana, até os sonhos foram banidos da pátria heideggeriana, a modernidade estética também se baseou no mesmo movimento de explicitação e de domínio da latência. $\mathrm{O}$ terrorismo analítico das vanguardas ${ }^{54}$ abalava a tradição na medida em que tornava explícitas as suposições nas quais se assentava o consenso entre o artista e o público. Se o público burguês é apresentado a um romance sem personagens ou sem início, meio e fim, então o público fica chocado, pois isso rompe com a regra básica da narrativa na mesma medida em que explicita essa regra subjacente. Esse tipo de procedimento acontecia em todas as artes, mas o problema da vanguarda é que o burguês chocável entendia rápido demais o jogo do terrorista estético e o número de experimentadores analíticos se democratizou na mesma medida em que a arte deixou de chocar.

Para voltar ao designer de atmosferas vivíveis e invivíveis, pode-se dizer que o homem - o "senhor do ente" segundo a célebre expressão da Carta sobre o humanismo, de Heidegger - não impera mais apenas sobre a natureza, mas constrói atmosferas e converte-se no "guardião do clima" (id., ibid., p. 138). O pastor do ser e o seu convite desmobilizador $^{55}$ para que nos repatriemos na guarda da obscuridade perde para o chamado do guardião do clima. Este novo guardião, assentado no avanço explicativo, configura atmosferas e modifica ambientes em uma velocidade que supera em muito a capacidade filosófica-cultural de criação de novos conceitos.

Esse atraso da formação teórica de conceitos em relação ao que fazem, por exemplo, arquitetos e militares, hoje em dia, é ironicamente semelhante à relação, explorada por Sloterdijk, que existe entre o tecnólogo do ar, o desenhista do ar e o fenomenólogo. Quando o segundo chega para descrever e explicitar o ar, o primeiro já o

\footnotetext{
${ }^{54}$ Esse tema de Esferas III já havia sido tratado no primeiro capítulo de Essai d'intoxication volontaire, tradução francesa de Selbstversuch-Ein Gespräch mit Carlos Oliveira, 1996 [Autoinvestigação: uma conversa com Carlos Oliveira]. Ali Sloterdijk mostra que o terrorismo analítico conduz à decomposição da forma e às nadificações quase budistas e que o esgotamento desta situação nos anos 20 e 30 obriga uma retomada da atenção pela forma e pela figura.

55 Tanto em $O$ sol e a morte quanto em Regras para o parque humano, Sloterdijk oferece interpretações da Carta sobre o humanismo, de Heidegger. Em Regras, ele afirma que a Carta apresenta o único chamado revolucionário realmente radical. Uma revolução para fora da metafísica. Retomaremos essa discussão no Adendo III.
} 
envenenou com gás e o aromatizou com perfumes, utilizando-se exaustivamente daquele pseudoimpensado. Como escreve Sloterdijk,

[...] os técnicos levam já cem anos de vantagem, trabalhando para assenhorear-se na prática do pretensamente impensado. Reforça-se a suspeita: um pensamento que permanece muito tempo fenomenologicamente ancorado, nos limites do mundo fenomênico se converte em aquarelismo interior e termina em meditação atécnica (id., ibid., p. 141).

O mundo técnico deixou para trás a província dos fenomenólogos. Quem ainda se apoia nas aparições naturais e confia no cosmos e na criação não sabe nada dos perigos que se corre após o terrorismo ter explicitado o ambiente. Persistir em meditações atécnicas é convidar ao sonambulismo e desconhecer a vulnerabilidade na era dos tóxicos. $\mathrm{O}$ ambiente explicitado pelo terror também se tornou progressivamente um lugar de bactérias e micróbios, um lugar cada vez mais suspeito. Depois de Pasteur e Koch, o invisível está repleto de inimigos. Com o discurso do meio-ambiente, a biologia teórica no início do século $\mathrm{XX}$ aposenta a ideia de que a vida possa se integrar em totalidades holísticas, pois, agora, cada vida tem um entorno e este entorno rivaliza ou está em relação de oposição com entornos estranhos. Não há nada mais ilusório do que amizade universal e "já não se pode pensar mais a integridade como algo que se consegue pela entrega a um envolvente benéfico, mas apenas como sucesso próprio de um organismo que se preocupa ativamente da sua delimitação com respeito ao entorno" (id., ibid., p. 154). A vida não é tanto participação e abertura, mas fechamento em si e seletividade que recusa participações.

Com a catástrofe da latência e a explicação do fundo, a dimensão tradicional se encolhe e a herança cultural já não transmite herança alguma aos deserdados, ${ }^{56}$ que doravante tomam tudo como "assunto novo" (id., ibid., p. 155) e como algo passível de "transformação continuada" (id., ibid.). O que era orientação implícita passa a ser objeto de escolha e aposta explícita. Posso eleger para mim uma identidade de "oprimido" ou de "irlandês protestante". As identidades prêt-à-porter estão confeccionadas segundo vários padrões "tanto individualistas quanto coletivistas" (id., ibid.). Se a dissolução da

\footnotetext{
${ }^{56}$ Eis um ponto que abriria uma interessante discussão com o pensamento de Walter Benjamin, na medida em que este buscou digerir e apreender esta experiência. Nesta tese, entretanto, foram abordadas, no capítulo 4, apenas as críticas de Sloterdijk ao filósofo das Teses sobre o conceito de história, quando também há, ao longo da obra sloterdijkiana, apropriações positivas e elogiosas a ele. Outras formulações da questão da des-herança encontram-se nos capítulos 1 e 2 (Essai d'intoxication volontaire, p. 7-38). Essa problemática é também analisada em Die schrecklichen Kinder der Neuzeit [Os filhos terríveis da modernidade\}, publicado na Alemanha em 2014, e na França com o título Après Nous Le Déluge (2016).
} 
latência cultural abre a era das identidades e da eleição da autoimagem, a quebra das latências naturais-somáticas leva os seres humanos modernos a uma relação problemática com a saúde, pois o excesso de explicação e de explicitação conduz a um alarmismo constante, caso da atriz Agelina Jolie, que tirou os seios preventivamente. A explicitação tematizadora no seu progresso exponencial conduz a desvantagens imunológicas. Saber demais ${ }^{57}$ gera um desejo de destematização e de refúgio na latência e na ingenuidade. Acaba-se por invejar os ingênuos que viviam na ignorância dos riscos. Por isso, os modernos terminam por criar uma espécie de segunda ingenuidade calculada a fim de poder deixar na sombra do não desdobrado temas e possibilidades muito alarmantes. Quando se escuta nas rádios e TVs todas as manhãs que é preciso abrir os olhos para os hormônios da tireoide, a hemoglobina glicada e o infarto, e essa lista se estende demais, então é preciso deixar alguns itens na "função standby de temas já explícitos” (id., ibid., p. 159) a fim de que alguma confiança abrace a vida alarmada.

Para sintetizar melhor a nova situação, Sloterdijk lembra que se mover no mundo explicado é mover-se após o terrorismo ter explicitado o ambiente, a vanguarda ter explicitado a cultura pelo imitar pejorativo e ridicularizante das coisas outrora habituais (crença, amor etc.) e a ciência ter aberto a caixa-preta da natureza, conseguindo assim substituí-la e protetizá-la. Mover-se aí é mover-se numa paisagem radicalmente transformada tanto material quanto cognitivamente. Mudou o mundo real e o mundo mental, pois ambos foram repovoados com os "resultados explicativos" (id., ibid., p. 164). Máquinas de todo tipo, ondas de inovação e de novas realidades atravessam todas as fronteiras: se a eletricidade, arrancada do fundo da natureza iria incubar a hiperluminosidade da cultura de massas, os micróbios, migrantes do invisível para o nosso convívio, farão a conversão das "populações modernas em sociedades higiênicas" (id., ibid., p. 165). Automóveis, micro-ondas, celulares e antibióticos são poucos exemplos das tantas coisas novas que transformaram a rotina das cidades, dos

\footnotetext{
${ }^{57}$ A importância do não saber e do desconhecimento vital e a existência de sistemas imunológicos mentais foram colocadas às claras por Nietzsche que, segundo Sloterdijk, é um dos pais da alergologia e do modo imunológico de pensar. Nietzsche sabia que os interesses cognitivos se afastam dos interesses da vida e, se no seu próprio caso, ele acolheu o interesse cognitivo em detrimento da razão vital, sabia dos custos e da dose de bravura e masoquismo necessários para sustentar esta posição. Sloterdijk cita a seguinte passagem de Além do bem e do mal: "A força que tem o espírito de apropriar-se do que lhe é estranho, manifesta-se num forte pendor a assimilar o novo ao antigo, a simplificar o complexo, a rejeitar ou ignorar o inteiramente contraditório [...]. A serviço dessa mesma vontade se acha também um impulso aparentemente oposto do espírito, uma brusca decisão de não saber, de encerrar-se voluntariamente, um fechamento das janelas, um dizer Não interiormente a essa ou aquela coisa, um não-deixar que algo se aproxime, um estado defensivo ante muita coisa conhecível, uma satisfação com o obscuro, com o horizonte que se fecha, um acolhimento e aprovação da insciência" (apud SLOTERDIJK, 2009a, p. 159160) (tradução brasileira da citação em: NIETZSCHE, 1992, p. 137).
} 
lares, das comunicações e do metabolismo humano. Embora a análise da absorção e da climatização dessas novidades nos " mundos de vida" precedentes seja complexa, podese dizer resumidamente que a maioria dos novos cidadãos mecânicos e epistêmicos acaba se infiltrando por ondas imitativas e porque se acredita que o "novo" contribui para o progresso social. ${ }^{58}$

A questão é saber onde estavam esses novos cidadãos epistêmicos antes de eles terem passado ao plano da realidade partilhada. Onde estavam entes como os micróbios de Pasteur antes deste último os trazer até o país das novas realidades? Onde estavam os raios radioativos de Madame Curie antes de ela começar os experimentos? Para Sloterdijk, as respostas mais conhecidas ao problema da diferença entre o não estar descoberto e o estar descoberto de algo e a questão derivada desta, acerca "dos modos de ser do descoberto antes do descobrimento" (id., ibid., p. 168), são equivocadas e falsas. A primeira resposta, a idealista, afirma "que as coisas descobertas não possuíam nenhum tipo de preexistência antes de sua percepção por uma consciência e de sua expressão em um discurso" (id., ibid., p. 169). Esta tese supõe a identidade entre ser e ser percebido, o que equivale a dizer que um lago ou o mar perderiam seu ser e deixariam de existir na medida do afastamento do observador humano. Já a tese realista complementar também é equivocada ao supor uma

pré-existência, objetiva e independente do conhecimento, do descoberto antes do descobrimento, representando-se o ser da coisa como algo do qual possa abstrair-se facilmente, sem que sua consistência perca em nada, pelo fato de ser percebida por uma inteligência (id., ibid.).

Essa concepção objetivista desvaloriza o descobrimento e os arranjos experimentais que facultaram a chegada dessa "nova entidade" na sociedade do conhecimento. A terceira via para uma resposta correta, Sloterdijk encontra em autores como Bruno Latour e Heidegger. Latour mostra a importância do descobridor não como um mero constatador de fatos, mas como alguém cujo papel ativo comporta a conformação da "coisa" a ser descoberta por meio de "suas conjecturas, suas observações, suas manipulações, suas descrições, seus ensaios e suas conclusões" (id.,

\footnotetext{
${ }^{58}$ No que diz respeito à complexidade da absorção dessas "novidades", Sloterdijk escreve que "uma parte das novas introduções são avaliadas pelos mercados, outra é moderada pelos regulamentos estatais, uma terceira é censurada por moralistas e comunidades de experts [...]. As inovações não socializáveis ou são eliminadas ou se transformam em parasitas perigosos: é o caso, por exemplo, da forte disputa em torno da integrabilidade da tecnologia nuclear" (SLOTERDIJK, 2009a, p. 165 e 167).
} 
ibid., p. 170). Isso é assim porque o mundo não é a totalidade das "coisas mudas" (id., ibid., p. 171) nem dos fatos comprovados ou não, mas "o horizonte agitado de todas as 'propostas' nas quais se oferece à advertência humana algo existente, possível e real, de modo proposicional ou provocativo" (id., ibid.). Ora, se o mundo propõe, o descobridor é aquele que desdobra as propostas do mundo e, ao desdobrá-las, articula novas entidades que acabaram de aparecer com outras já existentes, formando redes novas e mais compactas. Embora o tom seja radicalmente outro, pois as considerações de Latour no que diz respeito ao aumento das redes explicativas são muito otimistas, Heidegger não diz algo muito diferente ao assinalar que a verdade acontece na era tecnocientífica como um atentado ao ocultamento. Ali onde Latour via articulações, Heidegger enxerga "uma invasão, geradora sempre de violência, da vontade de saber na natureza reduzida a mero recurso" (id., ibid., p. 172). Para Heidegger, na modernidade, o homem já não acolhe a automanifestação da physis, que, ao se entregar a si mesma, deixa que ele a veja e a escute, mas ao contrário, o homem força e constrange a manifestação do ente "mediante investigação e desenvolvimento" (id., ibid., p. 175). Ao invés do claro-escuro do abrir-se fisiocêntrico, a organização coercitiva do "dado" sob a "luz de néon" (id., ibid., p. 176).

O exemplo máximo da anulação da autoepifania fisiocêntrica e da vitória do Gestell é a astronáutica tripulada. Uma nave ou estação espacial é uma ilha absoluta, uma cápsula que possibilita a respiração em meios irrespiráveis. O ser-aí humano no interior de uma cápsula orbital vive numa máquina de imanência, num artefato no qual todos os elementos de sua vida foram reconstruídos a partir de fora. Não há, numa máquina dessas, mais nenhum nicho de "pátria" ou de latência. Tudo foi reconstruído e protetizado a partir de uma visão excêntrica, radicalmente exterior. Já não há relação inocente com nada quando o olhar acostumado e tradicional dá lugar ao olhar que investiga a implantação de formas substitutivas. Uma coisa é admirar um olho e tentar "salvá-lo" (Husserl), bem diferente é examiná-lo com vistas à sua substitubilidade. Uma coisa é existir inocentemente como "aluno do ar" (Herder), outra é estar inteiramente dependente de sistemas abastecedores ou de ventiladores para fazer o ar circular. Se a experiência, em sentido tradicional, repousava na latência do implícito, então, para repetir a palavra benjaminiana, a experiência definha e dá lugar ao protocolo técnico. No mesmo movimento, a velha formação (Bildung) dá lugar ao download informativo.

$\mathrm{Na}$ astronáutica, não pode haver obscuridade nem erro: seres humanos são tematizados como "caixas-pretas biológicas" (id., ibid., p. 251) consumidoras de ar, 
água e fazedoras de dejetos e gás carbônico. A menor falha de provimento ou de reciclagem de "lixo" é catastrófica. Entretanto, mesmo navegando no vazio e bem longe da Terra, vale para os astronautas a situação moderna básica da conexão isolada, pois a “atenção semântica e psíquica dos astronautas seguirá dependendo quase cem por cento [...] do abastecimento exterior, dado que a demanda de sentido das pessoas a bordo está preenchida de fato exclusivamente pelo input das estações terrestres" (id., ibid., p. 253). No que tange à carga de trabalho de oito horas e ao lazer com filmes, jogos e músicas, o sistema é inteiramente aberto. A situação só seria um mundo autônomo e isolado se houvesse "uma semântica de bordo independente ou uma religião-espaço endógena" (id., ibid.). No plano "cultural", os cosmonautas utilizam repertórios de sentido já existentes fora do artefato para navegações ascendentes.

A astronáutica é o ápice da ação construtivista moderna cujo sentido último, segundo as páginas iniciais de Esferas $I$, é responder à morte de Deus e à liquidação do design cósmico e do projeto "alma do mundo". O mais extraordinário na construção espacial é que ela não conta com um "mundo da vida" pré-existente. A obra aeroespacial trabalha no vazio e na exterioridade e precisa implantar o próprio lócus,

um mínimo de "mundo de vida" no "não-mundo-de-vida". Com isso se desloca a relação normal entre o sustentador e o sustentado, o implícito e o explícito, a vida e as formas. A construção de ilhas é a inversão do habitar: já não se trata de colocar um edifício em um meio ambiente, mas de instalar um meio ambiente em um edifício (id., ibid., p. 254).

Nesse sentido, o engenheiro e o arquiteto que trabalham no vazio são demiurgos que criam tecnicamente uma ambiência a fim de que ela sirva de morada. Se uma tal demiurgia exorcizadora da latência levaria Heidegger a anunciar o perigo máximo e a possibilidade da salvação, Sloterdijk apenas descreve a nova configuração epocal sem nostalgia e sem crítica. Seu trabalho de cunho antropológico não pratica crítica nem desconstrução. Como um antropólogo explicitador poderia criticar a cultura que visita? E qual o impacto de um trabalho sobre a desconstrução da razão ocidental fora da ilha dos filósofos, mas entre engenheiros da NASA, especialistas em cérebro ou biólogos clonadores? Nem crítico nem desconstrucionista, o trabalho de Sloterdijk apenas mostra onde estamos quando estamos no mundo de hoje. Ele sabe que um deus não virá nos salvar e que não há uma contraforça capaz de competir com a decifração dos alfabetos nos quais o implícito estava escrito. Cientistas da vida, designers de tecidos, 
investigadores de arquiteturas atômicas e desenhistas de ambientes para implantação de mundos-de-vida no vazio não abandonarão sua marcha explicativa por causa de textos genealógico-desconstrutivos heideggerianos ou pós-derridianos. Ao deixar para trás a crítica melancólica de Adorno e a desconstrução heideggeriana, Sloterdijk estabelece uma nova relação com a modernidade. É preciso viver nas espumas! As "espumas vivem" (id., ibid., p. 25). Essa relação mais serena com a modernidade contribui para o surgimento de um "pensar diferente, sem se deixar desconcertar pelo páthos niilista que durante os séculos XIX e XX foi o acompanhante involuntário de uma reflexão decepcionada pela metafísica monológica” (id., ibid.). Não há como evitar que, cedo ou tarde, o rigorismo exigido na astronáutica descerá para a Terra e a velha política na qual o homem "sonolento e vago" (id., ibid., p. 247) se remetia a pressupostos não explicados dará lugar a uma nova situação. Nesta, é a própria Terra que se converte em uma nave espacial, na qual teremos de sobreviver. A ignorância e a vagueza serão imperdoáveis e teremos de acessar tecnicamente as instruções de uso para a navegação qualificada dessa nave cujo nome é Terra. As questões climáticas e hídricas, por exemplo, vão logo se impor e o management atmosférico já é reconhecido como "um politicum do mais alto padrão" (id., ibid., p. 266) desde as conferências do Rio de Janeiro e de Tóquio.

\section{ADENDO III}

\section{Sobre os extremismos de Heidegger lidos por Sloterdijk}

Se abordarmos o pensamento de Heidegger a partir do repertório imunológico proposto por Sloterdijk, o que fica claro é que Heidegger rejeita tanto o design de tipo metafísico quanto o conjunto das imunidades modernas. Ele não se sente em casa nem no primeiro tipo nem no segundo. Se a experiência fundamental no mundo metafísico é a da apreensão intelectual da coisa na sua forma aspectual, forma essa que, ao perdurar imune ao sensível e ao devir, lança a alma que a contempla no abrigo do eterno, a experiência moderna fundamental da entitude do ente é a representabilidade. Isso quer dizer que o ente só aparece na medida em que é colocado por um sujeito e obedece à sua legislação interiorizada. O sujeito humano é a condição do objeto e objetividade é exatamente a situação na qual o ente encontra-se sob a jurisdição do sujeito moderno. 
Ora, Heidegger rejeita tanto a metafísica platônica, que conduz ao endereço verdadeiro no suprassensível, quanto o programa teórico gnosiológico moderno, que faz do ente um prisioneiro do olhar do homem sobre ele. Nesse segundo programa, a Terra é paulatinamente convertida num condomínio de bem-estar que se autogere. Para Heidegger, a casa e a pátria não estão nem no além nem no mundo instalado provedor de conforto e "qualidade de vida". O filósofo de Freiburg pretendia reivindicar um terceiro tipo de experiência que não concedia a estabilidade da theoría grega nem o controle oriundo da investigação científica. Nem céu, nem laboratório! Esses dois mundos constituem exílio para aquele que guarda a memória da pátria. Estar longe de casa e de nós mesmos; isso está patenteado na experiência da dor. A dor sustenta a memória da reconciliação. A dor recorda a nossa distância da coisa (como advento, como mensageira) do outro (como vizinho do mistério) e de nós mesmos (como receptáculos ocos). A dor atinge o ápice na apatridade (Heimatlösigkeit). São sintomas dessa apatridade: a "interpretose" infinita das ciências humanas e a sua fobia da verdade; a imortalidade galopante nas ciências da vida e a conquista cósmica na ciência natural. Diante dessa aceleração desenraizadora, só a dor encarnada no pastor do ser constitui ainda uma salvaguarda do ethos originário. Mas o que guardam o mortal e o pastor do ser? E a resposta é: eles guardam o simples, a maravilha das maravilhas, o acontecimento fundamental de que o ente é.

Se os metafísicos, antigos ou modernos, ficam detidos na onipresença do ente, seja para saudá-lo conceitualmente seja para protetizá-lo ou melhorá-lo tecnicamente, o pós-metafísico reivindica o retorno à casa. Retornar para a casa ou curar-se da errância metafísica significa abandonar a entitude do ente como o sentido único do que é e abrirse para a experiência da perplexidade diante da doação e do surgimento das coisas. Trata-se de uma conversão na qual o ser humano deixa de ficar hipnotizado pelo ente e passa a habitar no rasgo da diferença que há entre o ente e o mistério da sua manifestação.

Pode-se dizer que aquele que lê Heidegger para além do mero domínio conceitual acadêmico é alguém que acolhe em si mesmo a experiência de uma negatividade radical e que aceita o convite de migração para fora da experiência do ser como presentidade. Lido pateticamente, Heidegger é uma chave terapêutica ou uma senha para abrir a porta para o precipício. Na medida em que o leitor se deixa conduzir pelo caminho de seu pensar, termina por encontrar acolhimento no precipício, e, nele aninhado - o que constitui uma posição paradoxal e rara -, experimenta o sentido do 
ser, não mais metafisicamente, como presença, mas como vinda e emergência. Ao cabo dessa experiência, recupera-se a memória do ser como um salto, e se é conduzido ao endereço de casa. Estar em casa, no sentido heideggeriano, é existir em um espaço de retração, suspensão e descolamento de onde se experimenta as coisas como um advento e uma chegada misteriosa. Aquele que corresponde a esse movimento de doação e de eclosão a partir do oculto já não é mais um titular ou um proprietário de suas palavras, mas é a linguagem do ser que fala através dele como se este último dispusesse de um aliado estranho cuja essência é exatamente ser canal aberto e desentupido para o ressoar dizente da oferta incessante do "dá-se" (HEIDEGGER, 1979, p. 284).

Quando o dizer é apenas uma correspondência agradecida ao acontecimento do ser, então ele já não é mais nem uma etiquetagem representativa da mera presença de algo nem expressão de alguma vivência interior. É um dizer silente e calado, uma vez que ele não esquece a autorretração e o autoesquecimento do ser: "Vazio e sem acontecimentos", nas palavras de uma poeta (Marina Tsvetáieva), volto para casa. Estou curado da longa errância! Sou agora uma janela sem ninguém, tornei-me "um ser impessoal [...] um espelho fiel do mundo" (TSVETÁIEVA, 2008, p. 143).

O que salta aos olhos na caracterização do pastor do ser é o extremismo dessa posição. Ele não é uma figura da reflexão nem da interioridade. Quem toma seriamente o caminho de Heidegger diz não ao belo, ao mundo eterno e também ao mundo interno. Diz não também à investigação científica e às suas construções, só restando como maneira de viver uma vagabundagem poético-ontológica fiel à palavra dizente. É por isso que Sloterdijk em $O$ sol e a morte se refere a Heidegger como o fundador de uma religião da clareira, religião cujo ensinamento único é o de que o homem deve acolher reverentemente o clarão inquietante e meditá-lo. Não há dúvida de que uma figura exposta e batizada na fragilidade como essa, numa época explicitada, de ocaso da latência, dependeria de desenhos técnico-jurídicos para sobreviver. Para Sloterdijk, assim como não há superação revolucionária da forma mercantil, ${ }^{59}$ também não há uma passagem das ilusões revolucionárias humanas (comunistas e nazistas) para a religião da clareira. A tese dessa religião soaria: "os homens devem conter-se e recolher-se mais do que alguma vez o fizeram" (SLOTERDIJK, 2007, p. 94).

\footnotetext{
${ }^{59}$ Para análise marxista do que deveria ser o ultrapassamento da forma mercantil, cf. Anselm Jaspe (2013).
} 
Assim como é difícil imaginar uma sociedade de desconstrucionistas ou de levinasianos que concedem prioridade ao sofrimento do outro, seria quase impossível conceber essa sociedade-clareira de vizinhos do ser. Como seria ela?

\begin{abstract}
Até que surja algo mais nítido, ela deve ser concebida como uma igreja invisível de indivíduos dispersos, dos quais cada um a seu modo escuta às escondidas o assombroso e espera as palavras nas quais se expressa o que a própria linguagem concede ao falante dizer (id., 2000c, p. 29).
\end{abstract}

Para Heidegger, apenas a saída do monólogo antropocêntrico com o ente para uma dialogicidade meditativa com o ser representaria efetivamente uma possibilidade de salvação diante da "trágica titanomaquia da metafísica do século entre o bolchevismo, o fascismo e o americanismo" (id., ibid., p. 31). Sloterdijk, entretanto, vê na figura do pastor do ser e do mortal heideggeriano, tocado pela humildade e pela fragilidade, um caráter nitidamente criptocatólico. Isso é dito não só em Regras para o parque humano, ${ }^{60}$ mas também em $O$ sol e a morte, em que Sloterdijk afirma que a tese segundo a qual não é o homem que importa "mas aquilo que supera o homem, servindo esse apenas como meio ou caixa de ressonância” (id., 2007, p. 87) é marcadamente católica. A desconfiança em relação ao homem e de que ele possa fazer algo de proveitoso a partir de si mesmo e de suas próprias forças é uma ideia agostiniana subjacente ao pensamento de Heidegger. Essa ideia reaparece na entrevista da revista Spiegel, na qual ao responder a uma indagação de Rudolf Augstein, Heidegger diz que "só um deus pode salvar-nos". Nesse sentido, e esse é o tema da Carta sobre o humanismo, só há esperança para o homem e para as coisas da terra se ele trocar a gramática ativista pela "gramática do acontecimento" (id., ibid., p. 88). Para o burguês, defensor da autonomia do sujeito, da razão e do agir, posições como essa são escandalosas e incompreensíveis. São identificadas com a mística e imediatamente abandonadas por ferirem o "bom tom humanista" e a "vaidade humana" (id., ibid., p. 89).

Sloterdijk, embora crítico de Heidegger em inúmeros aspectos, não se serve do diagnóstico de criptocatólico para condenar a obra do filósofo ao esquecimento. Seria reduzir a importância do pensador da Floresta Negra dizer que ele é apenas um Mestre Eckhart redivivo e que, na verdade, tudo o que ele diz já estava na mística cristã. É

\footnotetext{
${ }^{60}$ Texto disparador da famigerada polêmica com Habermas mencionada no capítulo 1 desta tese.
} 
óbvio que um leitor dos sermões de Eckhart ao se deparar com sentenças do tipo - " [...] o desprendimento é totalmente isento de toda criatura [...] o desprendimento fica tão próximo do nada que nenhuma coisa é suficientemente sutil para poder manter-se dentro do desprendimento, a não ser Deus" ou "estar vazio de toda criatura significa estar pleno de Deus e estar pleno de toda criatura significa estar vazio de Deus" (ECKHART, 2004, p. 5 e 12) - julga ter descoberto o âmago da obra de Heidegger após a Kehre. Embora pareça tentador substituir Deus por ser e resolver a charada-Heidegger, Sloterdijk lembra que o grande místico nascido em 1260 não viveu a explosão da bomba atômica e que Heidegger "não só a viveu como refletiu sobre ela" (SLOTERDIJK, 2007, p. 97). Nesse sentido, Heidegger - o único pensador do século XX que pode ser colocado ao lado de Platão e Agostinho e de Kant e Hegel, segundo o juízo de Sloterdijk - foi quem pensou filosoficamente o acontecimento de seu tempo:

os clarões de Hiroshima e Nagasaki foram, de certo modo, revelações que confirmavam a linha das suas reflexões. Os dois cogumelos atômicos, na sua opinião, surgiam das próprias entranhas do humanocentrismo: eram engenho e arte humana na sua mais genuína expressão; eram, simultaneamente, engrenagem técnica e explosão, a prova mais evidente da física moderna e, em certa medida, a autoexplicação mais ilustrativa não só da posição americana como da posição moderna perante o mundo (id., ibid.).

Se as considerações de Sloterdijk sobre o Heidegger pós-Kehre são muito interessantes, o mesmo pode ser dito das observações que ele faz da analítica contida em Ser e tempo no livro Esferas I. Não há dúvidas de que o projeto Esferas é uma tentativa de escrever o livro "Ser e espaço", o livro não escrito do Ocidente, mas que já estava "subtematicamente implícito na obra precoce de Heidegger" (id., 2003, p. 312). Esferas I é, certamente, a melhor continuação de Heidegger contra Heidegger. Ao desenvolver as análises heideggerianas do ser-em ou do estar-dentro aparecem claramente as deficiências de Heidegger, pois o "em" tem sempre um sentido de continente e de receptáculo. $\mathrm{O}$ "em" depende de comunidades originárias nas quais seres humanos vivem uns com os outros em uma imanência extática. ${ }^{61}$ Ora, esse sentido de continente e de receptáculo não se encontra no pensamento de Heidegger. Para este último, o ser-em tem mais o sentido do salto extático do que o do continente. É como se o heideggeriano permanecesse sempre suspenso numa movimentação suprema que

\footnotetext{
${ }^{61}$ Isso é algo que os arquitetos sabem muito bem enquanto teóricos do "em" que são: fazer uma casa ou construir um prédio é dizer como "alguém pode estar junto com alguém e algo pode estar em algo" (CORDUA, 2008, p. 179).
} 
desconhece a aterrissagem e o mergulho. A suspensão imposta pela angústia mantém o desassossego daquele que não se que aquieta no ente e no mundo, pois aquietar-se aí é perder-se e perder a movimentação. Sloterdijk escreve em Der ästhetische Imperativ: Schriften zur Kunst (O imperativo estético: escritos sobre arte) que o

ser-em pensado originalmente por Heidegger significa "êxtase", e isto é algo absolutamente extraviado (absolut verrücktes), pois designa o ser sustentado no interior do nada. $\mathrm{O}$ "em" já não tem a partir disso a condição do que contém, mas o sentido do extático. Consequentemente, já não sabemos realmente onde estamos quando estamos no mundo (apud CORDUA, p. 179).

Nessa passagem, o ex-reitor de Karlsruhe toca no âmago da problemática heideggeriana. Ele enxerga no olho do umbigo de Heidegger e desvenda o segredo até então inviolado do seu pensamento. Esse segredo, na verdade bastante simples, é o de que Heidegger não entende os idiomas da intimidade; os repertórios e os gestos daquilo que faz alguém caber no mundo e identificar-se com ele. Não se trata de ser do mundo sem pertencer a ele, mas de ser-no-mundo a ele pertencendo. Não se trata de celebrar a irrupção do Dasein no aí como um “enigma inexorável” (HEIDEGGER, 2006, p. 195), mas de como alguém cabe existencialmente num abraço, num quarto, numa casa ou numa universidade. Se Heidegger permanece detido numa semântica da revelação e da palavra quebrada é porque ele desconhece os meios pelos quais os homens se assentam na tranquilidade da palavra mundiforme. Não é apenas um equívoco teórico de Heidegger, mas uma impossibilidade para aquele que é fiel ao gênio da sua solidão. Há em toda obra de Heidegger esse outro texto, não propriamente silenciado, como diriam os psicanalistas, mas completamente inacessível, porque inexistente na experiência do filósofo. Quem pensa a imensidão do aberto e sua reposição incessante não pensa a capacidade humana de aproximar-se fortemente ou de estar complementado por outros que ofertam um lugar, um certo lugar. É apenas a partir desse lugar querido que surge a diferenciação entre o espaço aberto lá fora e a endosfera, o mundo relevante.

Acessar o umbigo de uma filosofia, a sua experiência matricial, o seu "núcleo intuitivo", como diria Bergson, é mais importante do que reproduzir tecnicamente a conceitografia de um filósofo. Sloterdijk, nesse sentido, apontou para a verdade de Heidegger ao salientar a outra verdade faltante. E qual é a verdade faltante? É a verdade da esfera animada pela inspiração compartilhada. Aqueles que coabitam neste dentro, ainda que não saibam explicitar a solda desta comunidade, sabem muito bem a diferença 
topológica entre viver ali, no coração do existente, ou lá fora, num outro lugar qualquer. Heidegger não consegue explicitar a diferença topológica essencial, porque não tem repertório para acessar o campo das intimidades. Ele partiu da ilusão individualista e do caráter solitário do Dasein e aí permaneceu. Essa é uma crítica fundamental que Sloterdijk dirige simultaneamente ao pensamento e à pessoa de Heidegger, uma vez que seus erros políticos se devem, em larga medida, a confusões e incompreensões no campo da intimidade. O que é se deixar absorver ou tentar se enraizar em um coletivopovo? Como discriminar o espaço da política do espaço da absorção microesférica? O que é mergulhar ou se deixar absorver em um outro ser humano? Questões como esta só podem ser respondidas por quem se apropriou da natureza medial e intervisitada do seraí humano. Muito embora o pensador Heidegger não se coloque em cena como Nietzsche, o "pensador em cena", 62 a leitura de Esferas I torna nítido que o homem Heidegger era, ele mesmo, um desenraizado e que sua filosofia jamais se aproximou do verdadeiro segredo dos desenraizados.

Uma das grandes virtudes teóricas de Esferas I e da ontologia da intimidade é a de poder situar e circunscrever várias obras que consagram e dignificam a experiência do self negativo como decisiva e que desconhecem a semântica do self verdadeiro positivo. Isso significa não só um reposicionamento de Heidegger, mas de toda uma constelação de autores como Bataille, Blanchot, Lacan, Derrida e neonietzscheanos como Robert Musil. Não se trata aí de uma literatura quase budista de "fuga do self' ou de "doutrinas neonietzscheanas contemporâneas da superação do self ou do "sujeito", conforme Charles Taylor (2011, p. 62). Esferologicamente falando, esse tipo de literatura consagra o self negativo ${ }^{63}$ porque a experiência do self e de autolocalização de si no mundo a partir de inclusões em continentes não se deu. $\mathrm{O}$ sujeito vazio ou o homem oco não é o mais originário, mas apenas a consequência de desencontros e de recuos nas participações. A própria suspensão imposta pela angústia, no caso de Heidegger, é mais um efeito de não expansão e de recuo do que um fenômeno originário. Nesse sentido, Esferas I reivindica a cena e o corpo dos filósofos. Sentenças do tipo "o eu é imaginário" (Lacan) ou "o eu é devolvido à sua impessoalidade essencial" (Blanchot) ou "a comunicação acontece apenas na suspensão do projeto"

\footnotetext{
${ }^{62} \mathrm{Um}$ dos livros de Sloterdijk sobre o filósofo do eterno retorno é intitulado $O$ pensador em cena: $o$ materialismo de Nietzsche.

${ }^{63}$ Para o esclarecimento da noção de self negativo cf. "Ensaio de filosofia fisionômica" (PESSANHA, 2014).
} 
(Bataille) são lidas agora como frases autobiográficas, no sentido de Nietzsche, de autobiografias em geral cegas para os fenômenos esferológicos.

Nesse contexto, é bastante interessante o fato de que Heidegger, nas raras ocasiões em que ousa mencionar o ser-para-o-início e formula algumas palavras sobre o sempre silenciado ser-aí infantil, como é o caso do curso de 1928-1929 intitulado Introdução à filosofia, os termos que aparecem são todos eles indicativos de movimentos de recuo e de esquiva. Movimentos de "não" e não de "sim": "Enquanto esses fenômenos como a repulsa, a rejeição, a defesa não forem esclarecidos em sua estrutura ontológica, não poderemos começar a interpretar um estado dessa natureza como o estado da criança em sua essência” (HEIDEGGER, 2008, p. 132). Não é estranho que a criança heideggeriana seja desde o início esquiva e negadora? Onde está o sim jubiloso da criança que, acompanhada do aliado, sente estar criando o mundo? Onde está a criança, que se estende, expandindo o seu corpo sobre o mundo?

Em primeiro lugar a interpretação primária precisa começar a mostrar como a mera repulsa por parte da criança distingue-se de uma rejeição. A repulsa é um mero esquivar-se de... No entanto, no esquivar-se já está presente uma determinada rejeição, uma recusa a... Ao nos esquivarmos de algo já está presente uma contraposição, ainda que não ativa. Precisamos fazer uma distinção entre repulsa, rejeição e defesa, defesa junto à qual se inicia o contramovimento propriamente dito, o contrapor-se. (id., ibid., p. 133)

Revela-se aí o segredo concernente à posição heideggeriana da retração e da suspensão implicadas na questão do ser. Ambas, suspensão e retração, radicam em um não fundamental. A questão do ser acontece no retrair-se interrogativo de uma criança cujo aliado comparece mas não fica presente nem sustenta continuidades. $\mathrm{O}$ aliado, que não se deixa tomar e pegar, oferta para a criança um estar-no-mundo como um estar num jardim de tântalo. Essa posição excitada-exaltada se evidencia mais claramente na leitura de diários e autobiografias de poetas que narram diretamente suas experiências sem filosofemas. É o caso entre tantos outros, de Marina Tsvetáieva e Fernando Pessoa. ${ }^{64} \mathrm{O}$ que há de comum em todos eles é o fato de que a perda do mundo brinda com o ganho do olhar. Tsvetáieva, poeta do ser e da revelação, escreve em seus diários, em abril de 1920, que o "homem que não está em estado de exaltação não pode ter uma

\footnotetext{
${ }^{64}$ Refiro-me aos livros Vivendo sob o fogo, de Marina Tsvetáieva, e Prosa intima e de autoconhecimento, de Fernando Pessoa.
} 
visão correta das coisas" (TSVETÁIEVA, 2008, p. 140). Para ela, como para Heidegger, só aquele que deixa o vazio intacto e a falha acesa não está dormindo. ${ }^{65} \mathrm{~A}$ posição acordada, entretanto, lida esferologicamente, não é dádiva do ser nem condição mistérica de poeta agraciado, mas oferta do aliado que não ofertou.

A discussão da esferologia com Heidegger pode ser sintetizada na diferença entre duas expressões: ser lançado (Geworfenheit) e ser sustentado (Getragenheit). Ao miserabilismo daquele que eclode no aí como um "enigma inexorável” e que é fundamento nulo e ontologicamente culpado, pois não esclarece o lance no qual é lançado, Sloterdijk opõe a riqueza do estar sustentado e mantido (Getragenheit) por um aliado que dá algo doando-se a si mesmo. Não se trata, portanto, de pensar a situação inicial como imersão numa "contingência sem fundamento" (SLOTERDIJK, 2009a, p. 575), mas como a riqueza de encontrar o que se busca presenteado pela solicitude e atenção do mundo. Com a introdução da noção de sustentação no vocabulário filosófico, Sloterdijk quebra o monopólio semântico das ontologias da carência. O ser humano emerge da riqueza porque, no espaço inicial da complementação, o mecenas oferece um presente presenteando-se ele mesmo. Essa informação primeira do estar no mundo sustentado abre "um preconceito afetivo sobre o mundo, que, se não é desmentido traumaticamente pela revogação, sedimenta-se em um ânimo fundamental de despreocupada liberdade de acesso a tesouros e oportunidades” (id., ibid., p. 573).

Se deixarmos agora novamente de lado a abordagem esferológica, há ainda um outro problema importante na análise heideggeriana desse ente ex-posto que rompe na clareira do ser: é o esquecimento da pré-história dessa irrupção. O fato de que quem aí irrompe é um antigo animal que se exilou progressivamente da natureza até tornar-se extático. A questão que se coloca é: se o homem era antes abarcado pelo ambiente, como é que ele saiu desse ambiente e migrou do convívio com os parentes primatas para os receptáculos autogerados extra-ambientais da cultura? Sloterdijk acredita que é preciso contar a história deste gorila com inclinações paranaturais, desse extraviado, pois a própria exposição à clareira não é tanto uma dádiva do ser, mas uma produção antropotécnica desse próprio ente que passou de inexistente à existente. A reconstrução sloterdijkiana substitui assim a análise ontológica do mago de Meßkirch por uma ontoantropologia que narre como o homem saiu da jaula ontológica na qual os animais estão presos (o ambiente) até o mundo e a pergunta pela verdade. Desde A mobilização

\footnotetext{
65 “[...] basta-me entrar numa sala onde há pessoas (é raro, mas acontece), que eu - com surpresa - vejo que todos dormem - menos eu" (TSVETÁIEVA, 2008, p. 658).
} 
infinita, que Sloterdijk atribui às análises de Heidegger um déficit de "substancialização antropológica" (id., ibid., p. 299). O desprezo deste último por questões genéticas e antropológicas, que ele considerava menores, tem como contrapartida o interesse sloterdijkiano de narrar sempre os começos e as transições de lugar. É fundamental para o filósofo de Karlsruhe mostrar que o existir humano é sempre migrante, sempre oriundo de algum outro lugar. E não é diferente agora quando se trata de esclarecer a passagem do ambiente à essência extática. Trata-se de tomar a metáfora heideggeriana do "habitar na casa do ser como indicativo do movimento do pensamento antropológico e perguntarmo-nos de que modo um ser vivo ainda pré-humano, um animal gregário [...] pôde empreender o caminho que o conduziu até a "casa do ser'” (id., 2011, p. 112). Ao reconstruir esse trânsito, Sloterdijk conta os acontecimentos mais importantes que foram progressivamente rasgando a ambiência e abrindo a janela do mundo.

\subsection{Explicitação sloterdijkiana do acontecimento ontológico}

Foi na savana africana que começou a repressão do ambiente e teve início a transição topológica dos hominídeos para os receptáculos antropogênicos. Essa autoinclusão de uma espécie de macaco na ilha do ser e nos climas interiores configuradores de humanos é o que Sloterdijk tenta esclarecer no capítulo 1 de Esferas III. Neste capítulo, intitulado "Para uma teoria das cápsulas, ilhas e incubadoras", o filósofo apresenta nove dimensões constitutivas da antroposfera.

1 - O quirotopo, o mundo-à-mão. Quando as patas se transformam em mãos, o fechamento na ambiência é rasgado e surgem as relações com as coisas. Quando o que está aí ambientalmente para garras ou patas (ou melhor, não está aí!) se transforma em algo utilizável pelas mãos é sinal que o mundo se anuncia. No uso das mãos começa a autoinclusão dos ilhotas na abertura extática que Heidegger chamou ser-no-mundo. “Quem é no mundo tem úteis à mão; onde há úteis perto, não pode estar longe o mundo" (SLOTERDIJK, 2009a, p. 281). Os seres humanos não são entes espirituais desprovidos de extremidade, mas "possuidores de mãos" (id., ibid.). Os entes, como ensinou Heidegger ao criticar a ontologia da substância e o primado do olhar, são originariamente à mão. E no quirotopo há úteis para bater, cozinhar, cortar, dormir etc. Os úteis para lançar possibilitam uma grande liberação do meio, pois o hominídeo que 
atira uma pedra já não precisa fugir e pode agir à distância. No gesto de lançar e acompanhar o sucesso ou fracasso do lançamento surge a incerteza paradigmática que está no âmago de todos os nossos projetos. O uso de ferramentas, armas e utensílios de ação à distância implica também em uma liberação da pressão evolutiva do corpo. Como os pré-humanos "se retiraram para trás de um muro de efeitos de distância, produzido pelo [...] emprego de utensílios de lançamento e utensílios-ferramentas" (id., ibid., p. 283), ele pode eliminar o corpo (Körperausschaltung), segundo a expressão de Paul Alsberg, e não precisa mais se especializar. A adaptação somática é deslocada para os utensílios. Apenas o cérebro e as mãos seguem se especializando, principalmente depois do advento da escrita.

Os utensílios para bater, como certos tipos de pedras, transformam o material menos duro e produzem entidades novas. Essas novidades chegam ao espaço humano e "anunciam que atrás do estreito horizonte do entorno há um espaço de expectativa, pelo qual aflui até nós algo novo, portador de sorte ou de desgraça; é algo que um dia se chamará mundo" (id., ibid., p. 286). Se o quirotopo abre para o novo e para o inquietante em algumas ocasiões, ele é também e, fundamentalmente, o lugar da rotina. O lugar daquilo que é próximo, disponível e familiar. No quirotopo, acontece de as mãos começarem a formar equipes e essa cooperação constitui uma primeira síntese "social". Já os utensílios compostos, que envolvem a ligação de um cabo a uma pedra, por exemplo, constituem as primeiras cópulas. A síntese lógica emerge "das categorias operativas, dos universais, das manobras quirotópicas" (id., ibid., p. 288). Quando começam a se afiar ossos e pedras e os canivetes adentram o espaço quirotopiano, tem início a potência analítico-divisória da razão. $\mathrm{O}$ ato violento de despedaçar é a semente de todos os processos explicativos. Os canivetes

proporcionam às coisas do mundo o status da divisibilidade. Com sua ajuda, os antigos quirotopianos convertem-se nos seres vivos que podem olhar dentro dos corpos: observam a um outro ser vivo não humano sob a pele, as plantas no seu tecido, as frutas na carne, as pedras no estratificado e granulado (id., ibid., p. 289).

O descobrir e o forçar à aparição têm no canivete o pioneiro paradigmático. Também as palavras remetem ao canivete e, "se os seres humanos têm uma palavra própria em cada caso para os seres e para as coisas que aparecem ao seu redor, é porque fazem uso de canivetes na boca (id., ibid., p. 289-290). A nomeação destroça a savana e cada palavra seleciona um pedaço de mundo. Se os pedaços cortados pela palavra 
seguem os cortes feitos de antemão no existente por ele mesmo, então se acreditará que a linguagem é correta. A diferença entre uma árvore e um animal, por exemplo, deve ser uma diferença objetiva no próprio existente. Para Sloterdijk, ainda em Platão impera o canivete, pois nele "o pensamento humano não é mais do que a consumação da ontotomia divina" (id., ibid., p. 290).

2 - Quanto ao fonotopo ou mundo das vozes, a experiência decisiva é a de que as primeiras ilhas humanas sonorizam-se a si mesmas. Alguém que caminhasse pela savana africana perto dessas primeiras ilhas notaria que elas soam permanentemente, emitindo e recebendo. Além do ruído dos utensílios e das ferramentas, escutaria também o "som quase incessante das vozes: de vozes infantis que se alegram [...], de vozes maternais que advertem [...], das vozes dos homens cooperantes que se animam" etc. (id., ibid., p. 291). Esses sons emitidos do grupo para ele mesmo formam um teto acústico. Este teto e a continuidade da entonação, a redundância, mantêm o agrupamento em forma. Não há interesse por tons diferentes, como se o grupo fosse uma emissora de rádio que só sintonizasse o "seu próprio programa” (id., ibid.). É também pela afinação do grupo que se nota se ele está "em alta" ou "em baixa".

O indivíduo só pôde aparecer quando o totalitarismo sonoro reflui e surgem práticas de silêncio. Já em Esferas I, Sloterdijk advertia que foram a escrita e a leitura que permitiram aos homens os exercícios de não comoção. A inteligência alfabética permitiu um afastamento do "denso clima de participação" (id., 2003, p. 247) reinante na oralidade. O individualismo contemporâneo - assunto central de Esferas III - não teria sido possível sem o sossego e a leitura e a discriminação entre as vozes coletivas e outro tipo de vozes.

Não existe o ser humano interior antes que o tenham demarcado os livros, as celas dos conventos, os desertos e as solidões; só depois de o ser humano ter se convertido ele mesmo em cela ou camera silens, pôde habitar nele a razão com sua voz suave. (id. 2009a, p. 295)

Se o retiro para a tranquilidade possibilitou a migração da onipresença da doxa para a "própria cabeça", também a diferença tradicional entre público e privado remete a modificações no fonotopo. Se o paradigma do público é o antigo orador que usa a palavra para atingir o corpo do grupo, seja para manter seja para transformar a disposição anímica dos reunidos, o paradigma do privado é o poeta solitário do século XIX que, na madrugada, se cura do "despotismo das vozes" (id., ibid., p. 296) e dos 
rostos. Se o privado é o lugar das comunicações suaves, o ruído coletivo é a marca do público. Nesse sentido, a fofoca é cidadã, pois ela carrega o que foi dito em murmúrios até a praça pública.

$3-\mathrm{O}$ uterotopo ou as incubadoras de mundo trata das mães. Foi entre os mamíferos que o animal-mãe se modificou e aconteceu a interiorização do ovo. O ovo não mais externo fez dos mamíferos os inauguradores da trama das dependências quentes. O valor das vinculações e o "risco de separação" (id., ibid., p. 298) aumentam quando nascemos de um interior materno e após o nascimento se enlaçou por muito tempo peitos e bocas. Não há muito disso nas aves e nos peixes, animais não enlouquecíveis. No caso dos hominídeos, o seu design psicobiológico requer uma "estreia simbiose mãe-filho" (id., ibid.). Sem o ambiente materno, o filho não amadurece, já observava John Bowlby antes mesmo de Winnicott. Todos os mamíferos nascem, isto é, mudam do meio líquido para o aéreo, mas apenas os humanos precisam chegar ao mundo depois de nascer. A vinda ao mundo depende das alianças esferológicas. Sem a formação das esferas e a produção de um espaço interior a ser transferido e repetido, a prioridade do exterior faria de qualquer um de nós seres não localizáveis e jamais junto-de-si-mesmos. A antecedência lógica/ontológica do estar fora condena os humanos à arquitetura do interior. ${ }^{66}$ Ser na ilha humana significa então "poder fazer uso da possibilidade de transferir situações interiores. Transferências deste tipo são realizáveis quando se alcança no exterior uma situação real que possa servir de envoltório ou de receptáculo para a repetição da interioridade em outro lugar" (id., ibid., p. 301). A repetição faz com que uma cena antiga se projete sobre uma nova situação exterior. Este movimento de "reprodução reiterante" (id., ibid.) assegura o espaço interior. Os que convivem juntos na ilha humana transferem coletivamente o interior anterior a fim de "dominar" o exterior.

4 - O termotopo ou espaço de calor e conforto trata das dádivas do fogo e da generosidade da sua irradiação. Quando o fogo queima domesticado no centro de uma roda, os homens se reúnem em torno dele e ficam contidos pela esfera calorífica. $\mathrm{O}$ fogo é assim o primeiro conforto além de possibilitar o cozinhar. Já em Esferas II, no comentário que Sloterdijk faz de um texto de Vitrúvio, fica claro que os seres humanos

\footnotetext{
${ }^{66}$ Como vimos no capítulo 1 desta tese, as esferas são "criações espaciais, imunologicamente eficientes para seres como nós em que opera o exterior" (SLOTERDIJK, 2003, p. 37). O uterotopo de Esferas III já se encontra delineado em Esferas I, principalmente no excurso 3 "O princípio ovo", no qual Sloterdijk oferece uma teoria da psicose. Cf. p. 302 de Esferas I (id., ibid). A psicose é uma mudança de envoltório fracassada, o que equivale a afirmar que nela há um colapso, uma quebra ou interrupção da transferência.
} 
são os mimados pelo caráter confortante do fogo. É um mimo duplo, pois ao redor do fogo experimenta-se "a própria irradiação do calor benfeitor e as conversas agradáveis [...] sobre esse agrado" (id., 2004a, p. 204). Para Vitrúvio, o fogo está na base da convivência humana e é o paradigma da comodidade. Se o mesmo fogo é partilhado por um grupo de aquecidos, então reina a solidariedade. Se alguns ficam mais atrás, numa roda um pouco mais distante do foco ígneo, então o socialismo térmico dá lugar à "sociedade térmica de classes" (id., ibid., p. 205). O ponto central das análises do termotopo é a questão do bem-estar. Para Sloterdijk, pátria é onde estamos bem e só há pátria quando há conforto.

Lidar com o fogo é estar entre a magia e o trabalho, pois a primeira dá abundantemente ali onde não se pediu, enquanto o segundo concede um resultado previsível. O fogo é um fator protetor e os mitos que narram a sua gênese sempre vinculam a sua presença a uma dádiva dos deuses ou de titãs. O fogo é um presente que "passa a ser posse permanente daqueles a quem se presenteia e que lhes permite a entrada na condição cultural” (id., 2009a, p. 307). Por isso, quem

entrega o fogo "pantécnico" (pyros pantechnos) converte-se em patrão das cozinhas, promotor da alquimia, possibilitador da cerâmica e da metalurgia, ofertador de conforto e advogado da redistribuição de luz e comodidade, em uma palavra: no autêntico titã da cultura e, em virtude dessas propriedades, no santo mais distinto no calendário da ilustração (id., ibid.).

Abordar o lugar do calor é explicitar o que é o bem-estar e a matriz do lar. Assim, Sloterdijk percorre todo o destino do topos térmico desde as primeiras rodas de fogo até o estado de bem-estar social, no qual há uma "generalização [...] do termotopo com meios técnicos de asseguramento" (id., ibid., p. 310). Esse recontar exaustivo que percorre múltiplas culturas detém-se principalmente no caso romano e na transição do paganismo para o cristianismo. Roma é importante para o filósofo alemão, pois lá o fogo do lar se vinculava diretamente ao fogo no centro do império. A equivalência entre casa e império era garantida por um fogo central vinculante. Se esse fogo central, no templo de Vesta, doador da imunidade e conformador da "síntese social” (id., 2004a, p. 209), pôde ser apagado na transição para o cristianismo foi porque a luz perpétua tomou o seu lugar: o mesmo lugar centralizante que comanda o imaginário imperial.

5 - Sloterdijk denomina erototopo o modo como os habitantes da ilha humana "organizam sua vida do desejo" (id., 2009a, p. 311). Esse é um campo intenso que tem 
no desejo erótico o seu paradigma. Aqueles que convivem estão sempre em uma tensão decorrente das diferenças entre os membros do grupo. Uma corrente de ciúmes é mantida por "olhares inquisitivos, comentários humorísticos, maledicências desacreditadoras e jogos competitivos rituais" (id., ibid., p. 311-312). A vantagem que alguns têm em relação aos outros, quer seja de posses ou de dotes físicos, faz com que massas irritativas atravessem constantemente o grupo. Aquilo que um dia será chamado de "sensus communis é a participação no clima de alerta dos ciúmes e antagonismos que flutuam livremente no grupo" (id., ibid., p. 312). Não há como ser diferente quando se tratam de seres uterotópicos e termotópicos!

Diante das vantagens e diferenças que uns têm sobre os outros, reina uma espécie de discrição. Finge-se, por assim dizer, que aquela que é tão mais bela que as outras, não é tão mais bela assim. Sloterdijk, exercitando o olhar kafkiano da exterioridade, olhar daquele que é etnólogo no próprio quarto, ${ }^{67}$ escreve que quem "se moveu durante um tempo suficientemente longo no erototopo percebe o esforço sutil dos habitantes para manter sua indiferença frente às diferenças desprezíveis, bem como sua pretensa impassibilidade frente às não desprezíveis" (id., ibid.). Entretanto, quando explode o ciúme e a inveja, o que é inevitável, a discrição dá lugar ao saque, e quem tinha vantagens é atacado e humilhado. A moral é a medida profilática para evitar a "peste afetiva" (id., ibid., p. 313) no erototopo. Começa com proibições e tabus e “evolui" nas culturas avançadas para tentativas de produzir uma "desinteressização ativa dos seres humanos com relação aos objetos de seus ciúmes. Isto se consegue apenas se em seu lugar se colocam bens superiores cuja natureza ideal permita uma repartição ilimitada e impeça toda propriedade privada provocadora" (id., ibid.). Esta elevação para o espiritual - platonismo, estoicismo, cultura monástica cristã, entre outras ${ }^{68}-\mathrm{e}$ da busca de um bem superior sofre uma derrocada no século XX, e os intelectuais passam a ironizar as "superestruturas" de tal modo que, desde 1914, a "Grande Política é a

\footnotetext{
${ }^{67}$ Esse olhar é, como já dissemos no capítulo 1, o próprio método sloterdijkiano. É um paradoxo que alguém que examine e enxergue esferas precise estar fora delas? Tudo indica que sim. A peculiaridade da obra de Sloterdijk reside no fato de que o olhar exterior elogia o interior: como se a perda melancólica do mundo viesse acompanhada de um grande amor por ele. É em um dos livros de entrevista que a sua metódica está melhor caracterizada: "eu começo de modo absoluto com o princípio do frio, ou, se quiserem, com o ponto de vista de quem não participa por completo no interior de uma situação. Temos de principiar metodicamente com a melancolia, com a observação desprendida e com os laços vitais rasgados. Um investigador em ciências da cultura é um doutor Strangelove: vive entre os seus semelhantes mas, por muito que lhe custe admitir, é simplesmente um membro formal do mundo da vida; é partir do exterior que vê essa comunidade ilusória chamada cultura. Dispõe daquilo que certos teóricos americanos chamam The Dark Gift of the Vampire (o dom obscuro do vampiro). Oscila entre a vida vivida e a construção maquínica" (SLOTERDIJK, 2007, p. 175).

${ }^{68}$ Sloterdijk considera a doutrina budista a "ética do desinteresse" mais interessante e avançada.
} 
universalização das lutas de ciúmes sem um nível superior" (id., ibid., p. 314) e resta saber como é que nós, modernos, lidaremos com esta situação de um erotopo cada vez mais aceso e excitado pela intensificação do consumo e da competição.

Em uma conferência realizada em São Paulo no dia 5 de outubro de 2016, Sloterdijk referiu-se à luta de titãs do século XXI como sendo aquela travada entre uma nova ética da humildade forçada e a continuação da elevação dos padrões de consumo. As questões metereológicas e climáticas no interior da "nave terra", segundo a expressão de R. Buckminster Fuller, exigem uma nova contenção e desaceleração. De um lado, a exacerbação expansionista moderna e do outro a contenção. Em que medida, perguntou o conferencista, a exigência de contenção poderá entusiasmar os jovens? Filosoficamente se trata da disputa entre o finitismo heideggeriano e o infinitismo hegeliano. Em $O$ sol e a morte, esse contencioso titânico emerge politicamente

na querela entre os ecologistas, que são, em suma, políticos da finitude, e os neoliberais e socialistas, que aparecem aqui como cúmplices das políticas da infinitude; neste contexto, [...] a intensa social-democratização do planeta explica por que a social-democracia significa, ao fim e ao cabo, o infinitismo da redistribuição, que depende por sua vez do infinitismo da produção capitalista (id., 2007, p. 184).

A questão política decisiva parece ser a de como integrar alguns bilhões de seres humanos na tecnosfera da nave terra ou, sinonimamente, no termotopo elétrico do palácio de cristal a fim de que o abismo da desigualdade diminua, sem que a nave terra entre em colapso.

6 - Ergotopo: a questão fundamental aqui é a de como um agrupamento submetido a um máximo de stress consegue manter-se coerente sem se desmantelar. Para Sloterdijk, a explicitação desta questão é "um dos acontecimentos-chave das ciências contemporâneas da cultura" (id, 2009a, p. 320). A teoria de Heiner Mühlmann (Die Natur der Kulturen. Eine Kulturgenetische Theorie, de 1996) é ergotópica, pois nela o fundamento do nexo social tem a ver com a cooperação no máximo de stress: o que faz de "um grupo uma unidade efetiva de sobrevivência é [...] a capacidade de sincronizar seus esforços em situações tudo-ou-nada" (id., ibid.). As situações-limite ou casos críticos são pensados pelo filósofo de Karlsruhe não como "a forma secularizada do milagre" (id., ibid.), como fazem os seguidores de Schmitt ao pensar o estado de exceção, mas como a "forma politizada de uma situação padrão biológica, a qual os 
corpos [...] humanos respondem com um programa inato, endocrinologicamente dirigido, de extrema liberação de energia e solidarização sintônica" (id., ibid.). ${ }^{69}$ Nessa ontologia da situação extrema, já praticada pelos primatas, a questão é qual a atitude a ser tomada diante do perigo. No caso do ser humano há até a possibilidade de se decidir pela serenidade.

Resumiu-se aqui apenas seis das nove dimensões da antroposfera, ${ }^{70}$ pois elas já são suficientes para retomar o ponto da discussão sloterdikiana com Heidegger e esclarecer que, para a ontoantropologia, a tese heideggeriana de que a essência do animal é mais distante de nós do que a do divino ${ }^{71}$ não pode levar ao esquecimento daquilo que aconteceu com um certo animal que acabou rompendo com os seus parentes primatas e se tornando mais próximo até dos deuses do que de sua antiga família. $\mathrm{O}$ habitar no claro, a conformação de mundo, é algo que aconteceu aos poucos para o animal antes privado de mundo. Sloterdijk, que frequentemente libera Heidegger do próprio jargão e o joga contra o espírito de sua própria obra, recusa aqui a recomendação pietista de que, com relação ao claro, só se pode fazer uma experiência meditativa para, ao contrário, investigar desde "baixo" e desde a animalidade o que aconteceu para que o ambiente se tornasse estreito e fechado demais para os nossos antepassados. O que ele oferece é uma narrativa da pré-mundanidade à mundanidade, injetando substância antropológica empírica aos conceitos ontológicos de Heidegger. Assim, Sloterdijk leva a sério a metáfora espacial da casa do ser, mas lembra que esta casa não estava pronta à disposição de nossos ancestrais. É preciso narrar a migração do ambiente natural para o nicho ontológico ou para a "casa do ser". Essa narrativa é a do distanciamento da natureza e do refinamento do hominídeo. No curso dessa transição há fenômenos importantes que antecedem a linguagem.

Como foi visto, na análise do quirotopo, Sloterdijk atribui às mãos um papel fundamental para o ingresso no espaço metabiológico e cultural. As mãos e as pedras

\footnotetext{
${ }^{69}$ A discussão sloterdijkiana do ergotopo e de Carl Schmitt será retomada no adendo IV desta tese.

${ }^{70}$ As outras três dimensões são o aletotopo, o tanatotopo e o nomotopo, que discorrem respectivamente sobre a verdade, a morte e a constituição normativa, todas presentes ali onde há ilha humana.

${ }^{71} \mathrm{Na}$ Carta sobre o humanismo, Heidegger escreve: "Provavelmente causa-nos a máxima dificuldade, entre todos os entes que são, pensar o ser vivo, porque, por um lado, de certo modo, possuiu conosco o parentesco mais próximo, estando contudo, por outro lado, ao mesmo tempo, separado por um abismo de nossa essência ec-sistente. Em comparação pode até parecer-nos que a essência do divino nos é mais próxima, como o elemento estranho do ser vivo; próxima, quero dizer, numa distância essencial, que, enquanto distância, contudo é mais familiar para nossa essência ec-sistente que o abissal parentesco corporal com o animal, quase inesgotável para nosso pensamento" (HEIDEGGER, 1979, p. 155).
} 
rasgam buracos e janelas no mundo circundante e impelem o homem ao aberto. A pedra ou outro instrumento contundente possibilita o distanciamento e a liberação da necessidade do contato corporal com o ambiente. Esse é um passo decisivo porque aquele que usa ferramentas e reduz o estresse direto na relação com o entorno começa a constituir o seu próprio receptáculo de moradia, o seu próprio recinto-casa. E este recinto (Ge-Häuse) inaugurado pelo "animal dissidente" (SLOTERDIJK, 2011, p. 123) é que passará a ditar a adaptação. Na medida em que a pressão do ambiente cede, a adaptação refere-se mais ao receptáculo autogerado do que à natureza. Se se acrescenta ao quirotopo a dimensão termotópica do calor e sua potência conformadora de nichos e libertadora das condições naturais, pode-se começar a vislumbrar que o ser humano que sobrevive não é "o mais apto no sentido de uma confirmação de atitudes no front onde as condições do mundo ambiente circundante são mais duras, mas o mais feliz, no sentido de ter podido aproveitar o clima e as oportunidades internas dos receptáculos" (id., ibid., p. 122). Fenômenos microesferológicos como a facialização e a premiação da beleza e do sorriso, estudados em Esferas I, mostram como a "evolução" do hominídeo se dá mais em relação ao receptáculo grupal que à pressão ambiental. Também o fato de que os sapiens adultos conservem formas juvenis e fetais (como a pele fina), a premiação da inteligência e a cerebralização são fenômenos de refinamento possibilitados pelo receptáculo.

Nota-se que o adentramento no recinto humano, ou "casa do ser", não é tributário primeiramente da linguagem, como defendem os heideggerianos, mas é fruto de práticas e gestos de distanciamento do ambiente circundante. "Bater, lançar e cortar [...] produziram e asseguraram o receptáculo humano" (id., ibid., p. 123), e o homem, por isso, é mais um filho da pedra e das batidas que com ela deu, do que da linguagem.

Vir ao mundo é, portanto, adentrar numa espécie de exo-útero, um recinto autogerado, que guarda o homem e simultaneamente o produz. Esse lugar é forte o suficiente para permitir ao animal exilado da natureza furtar-se às leis do amadurecimento e conservar os traços infantis e fetais. Este luxo concedido pelo habitáculo requer do homem um constante cuidado por ele. É nessa experiência que Sloterdijk enraíza o sentido do cuidado (Sorge) heideggeriano. O cuidado tem mais a ver com o asseguramento e a previsão das condições de bem-estar do que com a antecipação da morte. Para Sloterdijk, é apenas porque o homem "está condenado a se prover de luxos que se pode entender o ser como tempo" (id., ibid., p. 125). 
O homem é um ser refinado e do luxo. O refinamento desse antigo animal que passou a viver nas cápsulas culturais das ilhas humanas é comprovado quando essas cápsulas implodem ou explodem, quer por catástrofes naturais quer por ataques de animais ou outros homens. "Eles sofrem demasiadamente o fato inevitável de que, em caso de ataques externos, seu espaço interior, que geralmente se encontra em situações estáveis [...] acabe implodindo; agora se encontram, nos vários sentidos da palavra, nus e à mercê das devastações do exterior" (id., ibid., p. 135). Nesses momentos de crise, urge transferir o repertório das "lembranças e rotinas" para a situação de desordem. Sem esses processos de transferência, já mencionados no capítulo 1 deste trabalho, e de deslocamento das situações costumeiras para as estranhas, os sapiens não teriam superado "as penalidades crônicas de sua história" (id. ibid.). Transferência é também, segundo Sloterdijk, o que faz da linguagem a casa do ser. A linguagem é o "órgão universal da transferência" (id., ibid., p. 137). Ao contrário da palavra quebrada de Heidegger, o que Sloterdijk enxerga na linguagem é a produção de semelhanças e a aproximação do "estranho e inquietante até incluí-lo em uma esfera habitável, inteligível e revestida de empatia. A linguagem torna vivível a exposição humana ao mundo aberto, traduzindo os êxtases em enstasis" (id., ibid.). A linguagem é um agente doméstico na medida em que injeta o semelhante no não semelhante. Ela possibilita não a "morada no espanto", como escreveu Arendt a propósito de Heidegger, mas a morada no costumeiro e familiar.

A discussão sloterdijkiana dos primeiros receptáculos metabiológicos esclarece não só a diferença com a análise puramente ontológica de Heidegger, mas também, com a antropologia da carência de Arnold Gehlen. Para este último, o movimento de migração do animal humano do meio ambiente para as estufas protetoras da "couraça cultural" (id., 2009a, p. 534) aconteceu por causa da pobreza de instinto e da insuficiência biológica deste animal. Segundo o relato gehleniano, foi uma criatura fraca e incapaz, que se viu obrigada a construir as estufas culturais para compensar sua indigência básica. O ser humano é, para o autor de Der Mensch. Seine Natur und seine Stellung in der Welt, um ser de carências, um ser "incapaz para a vida em qualquer esfera da natureza realmente natural e originária” (apud SLOTERDIJK, 2009a, p. 532). Sloterdijk considera que esta narrativa está mal composta desde o início, afinal, como é que a história e a evolução natural teriam "produzido" e legado um vivente com tamanhas carências? De fato, de "uma história natural do antecessor do ser humano não pode deduzir-se uma dotação tão dramática de espoliações. A natureza abandonada a si 
mesma não conhece nenhuma transmissão exitosa de inadaptações ou debilidades mortíferas" (id., ibid., p. 533). Não há antes de nós, um primata frágil e refinado de pele lisa e sem pelos e com quinhentos tipos de nariz. Essas características e transformações são, elas mesmas, tributárias dos efeitos fortalecedores do receptáculo imunológico. Como já se viu, é pelas virtudes deste habitáculo que os seres humanos se encaminham para uma "tendência confortante, cerebralizante, e infantilizadora" (id., ibid., p. 534).

Sloterdijk inverte o teorema de Gehlen e mostra que, na verdade, o ser humano não é um ser-de-carências, mas um ser de luxo. A própria argumentação gehleniana aponta para essa direção evidente mas, para Sloterdijk, Gehlen estava dogmaticamente comprometido com a tese "modernizadora" do pecado original, segundo a qual o "homo pauper" (id., ibid., p. 535) é um ser-de-carências (Mängelwesen). O ser do luxo não é um ser que

recorre à cultura e às suas instituições para se transformar de um ser biologicamente impossível em uma criatura [...] apta para a vida; ao contrário, ele procede das circunstâncias de sua geração e educação de tal maneira que se aproveita de seu privilégio singular do receptáculo até em suas mais íntimas dotações somáticas, em sua capacidade cerebral, sua sexualidade, suas estruturas imunes, sua nudez (id., ibid., p. 534).

A tese anti-gehleniana da riqueza e do caráter suntuoso desse ser autoplasticamente $^{72}$ refinado mostra-se nitidamente quando se examina os dois “conceitos mais importantes do sistema de Gehlen" (id., ibid., p. 535): o de patência do mundo (Weltoffenheit) e o de descarga (Entlastung). O primeiro deles, a patência do mundo, implica para o ser humano uma grande complicação e peso, pois ele é um ser do qual se exige muito. Ele "vive, experimenta e reflete mais que qualquer outro animal [...] e está sobrecarregado estruturalmente. Sua condição fundamental, do lado sensível, se chama inundação de estímulos e, pelo pragmático, pressão de risco" (id., ibid., p. 536). Porque o ser humano não tem um programa inato de respostas ao ambiente, o seu ser-no-mundo tem um caráter de peso e carga, pois ele está imerso, nas palavras de

\footnotetext{
${ }^{72} \mathrm{O}$ tema da constituição autoplástica do ser humano, ou antropotécnica, é desenvolvido exaustivamente no livro publicado por Sloterdijk em 2009 na Alemanha com o título Du Mußt dein Leben ändern. Este trabalho enciclopédico, tanto pelo seu volume quanto pela sua vontade abarcadora, pode ser lido como um desenvolvimento, complementação e correção das teses ainda incipientes de Nietzsche, do último Foucault e de Pierre Hadot sobre os trabalhos de autoconfiguração de si mediante exercícios e a eleição de "atratores" específicos. (Recorde-se aqui que Sloterdijk estende este tipo de investigação das asceses autoformativas do humano para além do domínio da cultura ocidental, o que lhe dá um olhar ainda mais amplo que o de seus antecessores, Nietzsche incluído).
} 
Gehlen, no livro já citado, "em um campo de surpresas" (apud SLOTERDIJK, 2009a, p. 536). Ora, esse excesso de possibilidades não é indicativo de carência, mas de abundância. O homo sapiens tem inúmeras possibilidades e por causa de sua

natureza subespecializada, multiplamente adaptável ou "aberta" se produz, por um lado, uma receptividade excessivamente impressionável, e, por outro, um espectro extremamente amplo de opções de ação que abarca desde a medianidade trivial até as improbalidades da arte, a ascese, a orgia e o crime (SLOTERDIJK, 2009a, p. 536).

Vale dizer que, se há uma carga para o ser humano, é porque ele é rico e plástico demais. Apenas no sentido de uma necessidade de seleção redutora de complexidade ou de uma decisão torturante pode-se falar de uma carência no ser humano. Tal carência por excesso e abundância se assemelha ao constrangimento da pessoa bela e rica que não consegue decidir qual viagem empreender - se para o Tahiti ou para a Patagônia! e qual amante convidar para acompanhá-la.

É inegável que, com a noção de carga e descarga, Gehlen formulou algo fundamental para a compreensão da "economia geral da existência" (id., ibid., p. 536). O ser humano é carregado, entretanto, não por uma pseudocarência inicial, mas pelo excesso e pelo demasiado, pela "riqueza do extatismo sensorial e pragmático" (id., ibid.) e daí a necessidade dos mecanismos de descarga e de simplificação. Tais mecanismos reduzem a complexidade e

atenção primária pela riqueza; começando com a configuração modélica da percepção e com a automatização de cursos de ação, até chegar à normalização de expectativas de futuro mediante rituais e à exclusão de imprevistos por rotinas técnicas (id., ibid.).

A vida humana requer encurtamento e pede uma boa banalização. Caso contrário, ela seria cansativa, tensa e desgastante. Sem os hábitos e a institucionalização, a experiência de viver aberto ao mundo seria quase insuportável. Os mecanismos de descarga, simplificadores e restritivos, economizam assim uma energia que pode ser utilizada para "empresas superiores, mais ambiciosas simbolicamente" (id., ibid., p. 537). Ali onde Sloterdijk enxerga um outro excedente positivo, a acumulação de energias obtidas na descarga, energia essa que pode ser usada em processos mais interessantes, Gehlen vê um outro fator negativo, pois a descarga poderia liberar os indivíduos para experimentações perigosas que colocassem em risco a "reprodução 
simbólica da "sociedade" (id., ibid., p. 538). Gehlen temia que o anarquismo dos artistas nas subculturas estéticas do século XX pudesse contaminar mais do que uma pequena minoria, o que arruinaria a duração institucional. $O$ puro experimento irregulado assustava este antropólogo conservador que, próximo do grande inquisidor de Dostoiévski, acredita que a liberdade é uma exigência radical demais, só assumível por alguns poucos.

A síntese que se pode extrair dessa discussão filosófico-atropológica é que, embora Gehlen temesse o ser humano luxuoso, enaltecido por Sloterdijk, este último tomou dele os conceitos de descarga e liberação e fez deles a chave para compreender o impulso para a leveza que caracteriza a modernidade. O tornar-se leve da vida nas sociedades de opulência é o traço epocal decisivo e, muito embora Gehlen tenha tomado o partido do peso, as suas duas noções básicas constituem o que há de melhor no plano teórico para dar conta do fenômeno da grande leveza. Sloterdijk chega a afirmar, à maneira hegeliana, que os conceitos gehlenianos são, "efetivamente, seu tempo captado em pensamento" (id., ibid., p. 539).

Cumpre lembrar, entretanto, que o mesmo tipo de elogio concernente ao diagnóstico epocal e os afetos peso/leveza é dirigido a Heidegger. ${ }^{73}$ Este, assim como Gehlen, decidiu-se pelo peso, mas, na sua analítica da dispersão "roçou o núcleo do ânimo da época" (id., ibid., p. 550) e Sloterdijk lamenta que Heidegger não tivesse acolhido o chamado da leveza e nem se comprometido com a democracia e a nãogravidade, o que exigiria a "mudança do caráter de sua profissão [...] e a reciclagem do profeta em intelectual" (id., ibid., p. 553).

\footnotetext{
${ }^{73}$ Este tema será novamente abordado na última parte do capítulo 4.
} 
4. ERA HISTÓRICA E PÓS-HISTÓRICA 


\subsection{A era da conquista histórica}

Com a catástrofe morfológica do globo cósmico, entra em cena a superfície rugosa e irregular da terra. A terra não mais per-feita e não mais construída geometricamente requer agora uma investigação empírica:

O puro belo pode ser descansadamente deixado aos idealistas, visto que o meio-belo e feio são matérias para os empíricos. Enquanto a perfeição pode ser desenhada sem recorrer à experiência, os fatos e as imperfeições só se descobrem pela mesma experiência (SLOTERDIJK, 2008b, p. 26).

A terra pós-idealista, que perdeu o cobertor cósmico e o "envelope do firmamento" é agora um astro interessante para os seres efêmeros. É exatamente por ser interessante e irregular que ela vai ser alvo da investigação empírica e liberar as energias de desinibição e de ataque. Não se pode compreender bem a modernidade sem o conceito de desinibição. A terra doravante um corpo interessante é um corpo do qual podemos tudo reivindicar. A terra física real com suas dobras e erosões é ela agora que se deve circundar e captar, e os metafísicos dão lugar agora aos geógrafos e aos descobridores. Com a perda do envoltório cósmico, o lá fora já não é mais um em cima ascensional resultante "de um transcender a alma noética num além-da-terra e num supraterrestre" (id., ibid., p. 32). O lá fora é agora o céu aberto e infinito e vazio que tanto tocou Pascal. O espaço neutro homogêneo e externo é "condição de base das ciências da natureza modernas e [...] [o] princípio da primazia do lá fora propicia o seu axioma às ciências humanas" (id., ibid.). A terra é agora o lugar para onde sempre se tem de regressar e, ao contrário das ascensões antigas, a terra moderna é uma "terraaeroporto" para onde se volta a aterrissar.

A época moderna é a transição da "especulação meditativa da esfera para a práxis real da captação (Erfassung) e registro em um globo" (id., ibid., p. 36-37; id., 2004a, p. 713). Isso equivale a uma "revolução" do espaço no exterior homogêneo. Se na era metafísica a esfera cósmica especulativa oferecia uma segurança global, agora os homens são criaturas vivas que existem na borda de um corpo irregular. Eles migraram da proteção "sob céus centrados” para um lá-fora inultrapassável. Daqui em diante, os homens construirão o espaço-interior-de-mundo (Weltinnenraum), o palácio de cristal, onde convergem política social e arquitetura de interiores como lugar de imersão contra 
o frio exterior. Mas teremos de esperar uns 350 anos para que as visões deste palácio se tornem mais nítidas e que ele possa se afirmar como um grande Interior que transponha a exterioridade. No início, o que acontece é que a catástrofe da esfera metafísica colocou os homens em movimento e na ofensiva, e eles abandonaram o sentir-se em casa nos "seus espaços-interiores-de-mundo tradicionais e suas extensões e expansões" (id., 2008b, p. 35) para irem levar os seus projetos em lugares outros e quaisquer. Sloterdijk escreve que:

estes novos empresários das nações-piloto da expansão europeia já não estão radicados numa terra-mãe; já não se embalam nas suas vozes e aromas; já não obedecem aos seus pontos de referência históricos e aos seus polos de atração. Esqueceram-se do que eram as suas fontes encantadas, do que significavam as igrejas de peregrinação e os lugares do poder e das maldições que residiam nos becos sombrios. Para eles, a poética do espaço natal já não é determinante. Já não vivem para sempre na paisagem em que nasceram; já não respiram as suas poesias-baldaquinos sob os céus dos seus povos, antes aprenderam a levar os seus projetos adiante em lugares outros, externos, abstratos.

Doravante o seu lugar é o mapa, em cujos pontos e linhas passam a estar localizados em absoluto. Ele é o papel pintado rico de informação, o mappamundo que lhes diz onde se encontram (id., ibid., p. 36).

Para Sloterdijk, a essência da era moderna está contida no famoso texto de Heidegger de 1938, “A época da imagem do mundo": "a essência da idade moderna é a conquista do mundo como imagem. A palavra imagem significa agora: a figura do produzir representante" (apud SLOTERDIJK, 2004a, p. 712). Isso significa que aqueles que chegam do espaço de mundo pré-moderno, que era qualitativamente animado, encontrarão agora uma superfície exterior e terão de lidar com o predomínio de um espaço de coordenadas homogêneo. Todo e qualquer lugar na superfície da terra "passa a ser potencialmente um endereço do capital” (id., 2008b, p. 39) e essa é uma situação “indispensável para os vencedores, insuportável para os perdedores, mas inevitável para todos" (id., ibid., p. 37). Os primeiros navegadores transformam o Ocidente em Europa e saem na conquista das terrae incongnitae. Com as partidas para o Oeste, começam os movimentos "que desembocarão um dia no tráfico indiferente em todas as direções" (id., ibid., p. 43). Liberados do imobilismo da eternidade e do tempo circular do mito, o tempo da modernidade é o tempo do devir promissor e do sadismo cognitivo sob a forma da pesquisa e registro. 
Se os navegadores e geógrafos dos séculos XVI, XVII e XVIII lançavam-se ao mar para e por descobrir, já no tempo de Júlio Verne (1874) o mundo já ordenado não comporta mais heróis, mas apenas viajantes apáticos que se deslocam de um ponto a outro, correndo apenas o risco de chegarem atrasados.

A época moderna é também uma transição para o meio aquoso, uma revolução oceânica. São os mares que transportam os negócios mundiais e os fluxos de capitais. Nesta primeira globalização terrestre, o caráter especulativo dos negócios se faz presente, pois há trocas "interdinásticas entre proprietários de regiões longínquas dos quais, visivelmente, nem o comprador nem o vendedor sabiam exatamente onde se encontravam" o que era trocado (id., ibid., p. 52; id., 2004a, p. 736). O programa dos descobrimentos é radicalmente não contemplativo e cem "anos antes de Francis Bacon, os patronos e atores da volta ao mundo sabiam que o saber sobre as superfícies terrestres é um poder e um poder sob a forma mais concreta e mais lucrativa" (id., 2008b, p. 53; id., 2004a, p. 738).

Uma ilha perdida feito um ponto branco nos mapas da época, como algo a ser explorado, é um caso de investimento: se contraio uma dívida para partir rumo à sua conquista, na volta, posso saldar a dívida e ainda fazer reservas para novas expedições com riscos partilhados. É assim que surgem os empresários, "homens de nova têmpera, que querem criar a sua própria sorte e o seu próprio futuro, jogando com as oportunidades e que desejariam não as receber já apenas da mão de Deus" (id., 2008b, p. 55). Liberar-se das mãos de Deus é estar entregue à sorte e ao acaso. O empresário, essa figura central da era moderna, que soube positivar a dívida, fazendo dela algo estimulante economicamente, é aquele que encarna as posições da sorte e da roda da fortuna.

$\mathrm{Na}$ ontologia das oportunidades, o negócio é calcular os riscos. O amor pelo risco que se pode perceber nos europeus de 1500 significa apenas que eles

têm mais desejo de conceder crédito, do lado dos credores, e estão mais dependentes do crédito, do lado dos devedores, o que corresponde à mudança de paradigma econômico, que passa da exploração antiga e medieval dos recursos a economias fundadas no investimento. Com este tipo de ação econômica, a ideia dos juros a pagar dentro do prazo é convertida em assunções de risco práticas e em invenções técnicas (id., 2008b, p. 59; id., 2004a, p. 747). 
As páginas em que Sloterdijk descreve o movimento dos navegadores e de empresários rumo à conquista e ao mapeamento de um exterior, que é fonte de riqueza e saques, têm o tom de grandes lufadas de ar e de liberação. Em termos filosóficos, é como se o continentalismo enraizado da metafísica das substâncias cedesse lugar ao vitalismo dos fluxos. A tempestade de investimentos, desencadeada na direção do exterior, produziu em 350 anos a volta ao mundo de Júlio Verne e, em quinhentos anos, meio milênio, o palácio de cristal da pós-história, o ecúmeno capitalístico-informático atual.

Sloterdijk tem sempre em vista no seu recontar megalômano o nosso endereço epocal e o dizer não impressionista do lugar onde nos situamos hoje. É preciso que a filosofia dê aquilo que só ela pode dar: uma bússola epocal e uma narrativa vigorosa. A narrativa desemboca assim na descrição da global age. É nessa "clareira de um presente hiperextenso", nas palavras de Cai Werntgen (2009), que veremos definhar tanto o ativismo fazedor de história e a sua práxis quanto o guardião de outros possíveis (alémhomem), como também aqueles que gostariam que se abrisse uma nova lufada de história (superadores da metafísica). Aqueles a que assistimos nascer em 1500 são os pioneiros dos atuais global players. Homens para quem o globo é o "monitor onde se pode ter uma visão de conjunto sobre o campo do comércio generalizado dos investimentos" (id., ibid., 2008b, p. 60). Mas enquanto os homens da situação póshistórica são negociadores inibidos em meios densos e saturados, o que vemos no início da expansão europeia, com sua partida para uma exterioridade desenraizada, é a subjetividade e a desinibição primária, que faz passar da teoria à prática. É essa passagem que constitui o núcleo do ser sujeito. Subjetividade é uma passagem à ação por conta própria. Para Sloterdijk, a subjetividade moderna não é uma agência do controle de si próprio, como pretendia a Teoria Crítica, mas que o sentido "real do advir-como-sujeito só pode ser compreendido a partir do armamento e da autodesinibição do ator" (id., ibid., p. 66).

A experiência nuclear da subjetividade da época moderna é a de que os sujeitos "se armam para se tornarem agentes capazes de agir aconselhando-se a si próprios, persuadindo-se a si próprios, dando a si próprios o sinal da desinibição dos atos - ou então arranjando quem o faça por eles" (id., ibid.). Quanto menos conselheiros, astrólogos e incentivadores de projeto, melhor. A autodesinibição garante uma ofensividade maciça, e nesse caso, o sujeito é autônomo, mas ele também pode agir como um possesso ou um autômato se o agente desinibidor for exterior a ele. Nesse 
sentido, os primeiros sujeitos da era moderna foram os jesuítas: soldados do agir evangélico que se colocavam sob o alto comando do papa. Nos jesuítas, a "obediência de cadáver" mostra a união entre a mais elevada motivação e a pura disponibilidade. As gerações posteriores transformariam esse papa em mandamento moral, decisão e outras formas de papado interiorizado. O importante é que se garanta a passagem para a ação e a desinibição desejada.

Outra figura importante de desinibição é o ideólogo. O ideólogo desinibe o seu cliente em nome da "história". Está ligado aos contextos revolucionários e às convulsões políticas pós 1789. Revolução, para Sloterdijk, é quando se afasta o senhor exterior e "se eleva a liberdade de empresa e de expressão das camadas médias ofensivas ao nível de ponto de partida de uma nova legislação” (id., ibid., p. 71). O revolucionário é um sujeito expressivo-expansivo que, unido com outros, pretende "desativar [...] as qualidades do real que oprimem, comprimem e deprimem” (id., ibid.). O problema do revolucionário é o momento pós-revolução, pois retirado o senhor cuja função é liberar a desinibição nos subalternos (implicada pelo direito de dar ordens), essa função terá de ser retomada pelo próprio sujeito.

Os ideólogos operaram entre 1793 e 1968, quando surgem os consultores. Se os ideólogos oferecem aos atores slogans desencadeadores de agressão numa guerra generalizada, ${ }^{74}$ os consultores operam a desinibição no terreno menos violento da concorrência.

Por onde quer que lancemos os olhos, ratifica-se a forte ligação entre subjetividade e ofensividade, que caracteriza a época moderna. Trata-se de uma cultura de atores. Atores que dão saltos para frente no desconhecido. Sloterdijk considera, entretanto, que esses atores não souberam encontrar uma linguagem e um modo de autocompreensão à altura das energias da ação liberadas. Com exceção de alguns autores marginalizados e excluídos do cânone, a "filosofia europeia da época moderna [...] quase sempre silenciou [...] o evento central do seu tempo, a captura do mundo pelas forças mercantis e imperiais e a desinibição que permitiu aos atores entregarem-se à pura atividade de agressão" (id., ibid., p. 76). O saber ofensivo encontra-se mais nos diários de bordo de Cristóvão Colombo e nas páginas de Melville do que na filosofia,

\footnotetext{
74 "Uma vez que os ativistas intelectuais descrevem o mundo como o teatro de uma guerra entre partes inconciliáveis - entre o progresso e a reação, o trabalho e o capital, o sedentário e o nômade - o seu discurso assume mais ou menos os traços de uma ordem de missão na guerra mundial generalizada; o tom corrente dos radicais no combate é pois exterminista" (id., ibid., p. 72).
} 
que falhou em pensar a expansão europeia, a construção de máquinas e a guerra de movimento.

Se a questão é dizer algo sobre a própria força de iniciativa, então a inspiração por um genius faz do ator um possesso. Do mesmo modo, a ideia de um espírito criador desloca o ator do "cerne do ato" para referi-lo a instâncias suprapessoais. Quando a filosofia aceitou a vinculação entre espírito e ato, como é o caso de Hegel - que fez da aparição de Napoleão uma necessidade, pois havia que concentrar "num personagem de chefe as ideias dinâmicas de 1789 e as necessidades de ordem do Estado de Direito burguês" (id., ibid.) -, então, nesse caso de elogio da ofensividade, teríamos de aceitar expressões como "alma do mundo" ou "síntese do espírito e da força de ação", que nada esclarecem acerca de uma energética inteligente nela mesma. Para Sloterdijk, a questão é esclarecer a "imbricação entre o elemento energético e o elemento inteligível na nova cultura de atores" (id., ibid., p. 77). Embora os filósofos da existência constituam para Sloterdijk apenas um pelotão atrasado em relação a literatos, que exploraram muito mais radicalmente a questão do ator, ele vê no Ser e tempo, de Heidegger, e na noção de ser-lançado-no-mundo (In-die-Welt-geworfen-sein), os rudimentos de uma tal energética inteligente. Isso porque o projetar heideggeriano é uma espécie de ofensiva autoiluminante que abre caminho, reconsiderando o trajeto a cada nova situação, e esse movimento não compete a um sujeito autorreflexivo, pois não há uma consciência que preexista ao projeto. O inteligível no caso heideggeriano não é oriundo de uma submissão ao ideal teórico, mas tem a ver com um orientar-se pré-teórico como um filhote de águia que descobre como voar e para onde ir apenas durante o seu primeiro voo. Segundo Sloterdijk, se as filosofias existenciais do início do século XX "tiveram um alcance histórico, foi porque realizaram explicitamente a passagem da reflexão para a projeção. Limparam o campo de visão sobre a dinâmica da mobilidade originalmente luminosa antes da reflexão e da inibição” (id., ibid., p. 78). Para o filósofo de Karlsruhe, entretanto, ainda que o "academicismo audacioso" de Heidegger tenha avançado, ele é ainda muito tíbio e deficiente se comparado com a investigação da subjetividade dos atores realizada pelos escritores. Com a exceção de Fichte e Nietzsche, Bacon e Hobbes, Sade, Spengler e Bergson, a incapacidade dos filósofos para pensar a ação deriva não só do privilégio conferido à atitude reflexiva que concede o primeiro lugar à inibição em relação à ofensiva, mas principalmente porque para pensar essa energética da ação é necessário adentrar em um campo onde a diferença entre energia legítima e energia 
criminosa não está ainda dada. Esse é um dos motivos pelos quais a cultura da reflexão evita a investigação do mundo da ação. Aquele que pretenda,

como o Fausto de Goethe [...] colocar seriamente a ação no início, não possui efetivamente à partida nenhum critério que permita dissociar com suficiente clareza as empresas econômicas, as expedições políticas, as missões religiosas, as criações artísticas daquilo que o mais das vezes se aparenta estritamente com este tipo de operações: o crime (id., ibid., p. 79).

Um ser de ação jamais saberá de início se após a ação ele será tomado como um palhaço ou um criminoso, e a maioria dos filósofos não teve coragem de consultar e de incluir o ímpio, o aventureiro e o criminoso nos seus textos. Sloterdijk considera que essa castração foi decisiva, pois ela impediu os filósofos da era moderna de apreenderem o seu tempo em pensamento. Eles não puderam olhar com clareza para as verdadeiras manifestações do "élan modernizante". Os poucos que conseguiram um bocado desse olhar menos inofensivo foram banidos do cânone, como é o caso de Sade, e quem pretendesse reivindicar o nome de Hegel para esta lista ouviria de Sloterdijk que Hegel é possivelmente um 'lobo com pele de cordeiro, pois o seu 'espírito do mundo' pragmático só exprime uma criminalidade superior que sabe sempre abrigar-se a tempo sob o teto da necessidade juridicamente protegida" (id., ibid., p. 80).

Inibição e desinibição são as noções centrais. É preciso pensar os agentes inibidores e também as agências de autopersuasão desinibidora, e Sloterdijk acredita que foi Dostoiévski quem melhor mostrou o funcionamento da autopersuasão desinibidora dos sujeitos atores na filosofia moral, contida em Crime e castigo. Raskolnikóv liga indissoluvelmente inovação e criminalidade ao reivindicar que seres excepcionais podem passar por cima da lei moral. Essa diferença entre seres excepcionais e vulgares é retomada por Sloterdijk em termos da teoria dos processos. Nos termos processuais, a cisão pseudoantropológica entre excepcionais e vulgares diz respeito a uma diferença de velocidades entre indivíduos avançados e atrasados. Os primeiros, por se encontrarem em pesquisas de vanguarda, produções fora dos padrões e "saídas mais ousadas" (id., ibid. p. 82), acessariam novas verdades e realidades, instalando assim uma questão aos atrasados, pois teriam de responder se vão recuperar o atraso ou desconsiderá-lo. A ontologia do avanço em Dostoiévski vincula a desinibição da ação a uma síntese de excepcionalismo, inovacionismo e evolucionismo (id. ibid.). Mas se para o autor de Crime e castigo, o modernista Raskolnikóv desintegra a 
comunidade e fragmenta a unidade do gênero humano, o que equivale a dizer que a sua desinibição contém elementos diabólicos, foi apenas com Nietzsche que a pura ofensividade se viu liberada e não mais devedora do primado da inibição. Sloterdijk denomina "pragmatismo dionisíaco" a "absolvição de todos os que sentem em si a fagulha do ato" (id., ibid., p. 84). O convite a um gesto sem álibi e a uma energética da ação acontece no próprio texto filosófico, que, na forma de hino, é ele mesmo um convite à ofensiva. Vale dizer que o próprio texto se dá como exemplo de uma energética afirmativa e "com a força de penetração de uma mensagem evangélica autogerada, que se dirige a todos e a ninguém, o ato de fala híbrido de Zaratustra repete a travessia do Atlântico - só a partir de então se pode dizer que o ato de Colombo chegou ao pensamento" (id., ibid.). Em Nietzsche, o júbilo da ação é tão grande que já não se trata de uma ontologia dos avanços que alguém tem, mas do grande avanço que alguém é.

Mas os hinos de Nietzsche são hoje ultrapassados e, depois do declínio da velha Europa, as delícias do unilateralismo da ação histórica são reivindicadas pelos terroristas, e apenas alguns atrasados cantam ainda o romantismo da ofensiva. Isso porque, na existência em meios densos e saturados, a inibição recíproca se torna a marca distintiva daqueles que vivem no interior do palácio de vidro. Entre integrados e reconhecidos, já não se escutam os diktats unilaterais nem velhos slogans de ação. "O desemprego em massa dos atores é o rótulo da época” (id., ibid., p. 193). Na era da globalidade consumada, o "estado de vizinhança forçada com inúmeros coexistentes casuais" (id., ibid., p. 192) faz com que esses coexistentes tendam à inibição recíproca. Isso significa que o salto nietzscheano da ação - excetuando as subculturas teatrais e psi com suas igrejas e guichês vitalistas distribuídos no interior palaciano - parece hoje história da carochinha. Para Sloterdijk, o jogo da história do mundo está já ultrapassado para os europeus e, doravante, dentro do sistema mundial, sempre que chegarmos a algum lugar, devemos saber que muitos já chegaram ali antes de nós (id., ibid., p. 170) e sempre que formos nos exprimir acerca de algum assunto jamais faremos independentemente do discurso.

Mas antes dessa era de saturação e cristalização pós-histórica, as ilhas hoje turísticas com seus grandes resorts e campeonatos de surf eram ilhas ainda virgens e promissoras. Quando a catástrofe morfológica que pôs fim à esfera metafísica (morte de Deus) lançou o homem moderno na exterioridade, a dinâmica ascensional deu lugar à coragem das travessias. Foi esse deslocamento da transcendência para a horizontal (id., 
ibid., p. 88) que possibilitou a utopia como escola de pensamento. A utopia é o wishfull thinking das ilhas perdidas à nossa espera. Quando os homens saem ao mar só existem os imperativos "Avante" e "Para frente". Quem quer recuar e desistir tem a cabeça cortada. As ideias de progresso constante e de enriquecimento geral migraram dos navios para as condições da vida sedentária do século XIX. O progressismo veio dos mares e seus conquistadores. Se cada barco que vai ao mar encarna uma psicose, pois encara diretamente a exterioridade, o barco é "também um capital real flutuando nas águas e, como tal, parte da permanente revolução do fluxo" (id., 2004a, p. 763). O capital investido deve partir e voltar multiplicado até a conta de origem. O retorno do investimento é o movimento dos movimentos. Se o dinheiro deve voltar multiplicado após a viagem pelo mar, a questão decisiva é distinguir uma nau de loucos de uma nau racional, pois a segunda tem maior chance de regresso. E é aí que começam a surgir o seguro e o cálculo (e a distinção entre razão e loucura).

O sistema nascente dos seguros é um dos precursores da modernidade sistêmica na medida em que se defina a modernização como uma gradual substituição de vagas estruturas imunitárias simbólicas, do tipo das interpretações religiosas últimas dos riscos da vida humana, por prestações de segurança sociais e técnicas exatas. Em certos pontos essenciais, o seguro das profissões comerciais toma o lugar do que até aí parecia estar nas mãos de Deus. (id., 2004a., p. 766; id., 2008b, p. 96)

Se Deus era o zelador do destino, pouco a pouco ele é substituído pelas imunizações modernas como a seguridade social, as instituições médico-higiênicas e o Estado de bem-estar. Já na situação pós-histórica, a hegemonia do seguro inibe todo ativismo onde haja risco de vida e surge a cultura da perturbação e do "acontecimento" como antídoto ao tédio imperante. Na transição para a modernidade, os homens deixam de ter uma relação com o absoluto para declararem-se "eles próprios casos de uma média estatística [...] e o sentido do ser reduz-se ao direito de reclamar em caso de dano normalizado" (id., 2004a, p. 767; id., 2008b, p. 96).

A filosofia de Descartes é emblemática desse momento e ela oferece um chão inabalável na medida em que encontra o ponto interior de certeza, que se deixa discernir pela observação imediata da dúvida por ela mesma. Mas essa modernização da evidência apenas produz uma reorganização da imunidade simbólica sob o signo da certeza. Levaria ainda muito tempo para que a fortaleza territorial da evidência desse lugar ao espírito náutico, que prescinde de fundações e de certezas, mas depende apenas 
de "pontos de transbordo, de parceiros no estrangeiro, de relações portuárias inspiradoras, de objetivos afastados e de uma dose de energia criminosa tornada civil" (id., 2008b, p. 98).

Se os filósofos alemães, excetuando Fichte e Nietzsche, não estiveram à altura de pensar a ação, agora acontece o mesmo no que concerne à experiência matricial da modernidade, pois esta está no chão dos navios e não mais no chão da pátria como terra, ou princípio original. Sloterdijk considera estranho que, ainda no século $\mathrm{XX}$, pensadores como Edmund Husserl colocassem a terra como princípio e "pátria original" e que esse telurismo pré-moderno o impedisse de questionar a razão que quer que nos fundemos em um solo. O mesmo se pode afirmar de Heidegger, que se recusou a ir ensinar em Berlim, porque o oráculo do ser só se manifestaria na província e no local. O pensamento alemão porta uma fisiocracia que rejeita a mobilidade e a superfície náutica e confere importância só àquilo que vem da ligação com o solo. Em Esferas III - onde Sloterdijk mostra a aceleração do movimento explicativo (e de soletração do alfabeto do implícito), principalmente a partir da Primeira Guerra Mundial e da tematização do ar e da atmosfera (atmoterrorismo) -, ele volta a insistir na inatualidade da fenomenologia husserliana (pois não há como fazer uma descrição fenomenológica da maioria dos aparelhos e instrumentos que temos em casa!) ${ }^{75}$ e no caráter ultrapassado das metáforas camponesas, vegetais e fisiocêntricas do pensamento heideggeriano. Embora o contexto ali não seja o da rejeição ao espírito náutico, mas uma discussão da epocalidade do habitar, Sloterdijk escreve que

\begin{abstract}
por um olhar retrospectivo à sua gigantesca obra se entende que ele fosse o proto-ontólogo, transferido ao final de sua época, do abrir-se e do deixar crescer vegetativo. Em meio de produções, inversões e bombardeios incontáveis, o maior pensador da antiga Europa, duvidando no limite entre mundo do crescimento e de projeto, segue concebendo a aparição nada espetacular do amadurecimento como o arquétipo do acontecimento decisivo (id., 2009a, p. 394).
\end{abstract}

No que diz respeito ao mundo náutico, o problema da filosofia alemã foi ter ficado "até o século XX ligada às atmosferas e às morais de pequenas cidadesresidência de província” (id., 2008b, p. 98). Tanto os sonhos do Egeu em Tübingen turvaram o encontro com o mar por causa do pensamento idealista quanto Kant que também pensava na direção dos ventos da contrarrevolução terrestre. Prova disso é a

\footnotetext{
${ }^{75}$ Conforme tratado no capítulo 3 desta tese.
} 
famosa imagem da Crítica da razão pura em que o entendimento puro aparece como uma ilha, "país da verdade" cercado pelo vasto e tempestuoso oceano, "a pátria da aparência". Foi necessário aguardar por Schopenhauer para que a filosofia alemã se aproximasse da fluidez e da flexibilidade da subjetividade modernizada. Schopenhauer parte de um mundo fluidificado: "a sua vontade é a primeira manifestação de um oceano dos filósofos - o sujeito navega nele na casca de noz do principium individuatonis, protegido pelas ilusões salvadoras do espaço, do tempo e da centragem no ego [...]" (id., ibid., p. 101). Nietzsche e os vitalistas somam-se a essa descoberta na tentativa de refluidificar os sujeitos necrosados e é efetivamente com este último que o pensamento deixa de ser o "olhar em torno, em devoção da razão, na esfera transfigurada do ser" (id., ibid., p. 102). Mas não é necessário percorrer todos os autores examinados por Peter Sloterdijk. Cumpre reter o essencial da discussão, a saber: se a busca das justificações últimas e do fundamento inconcussum tem a ver com o pensamento terrestre, o seguro e o cálculo das probabilidades remetem-se ao elemento náutico. E feita a distinção, reconhecer que a técnica dos seguros levou a melhor na modernidade.

\begin{abstract}
No mercado das técnicas de imunidade da época moderna, o sistema de seguros impôs-se totalmente com os seus conceitos e os seus procedimentos, face às técnicas filosóficas da certeza. A lógica do risco controlado revelou-se muito menos onerosa e muito mais praticável do que a justificação última da metafísica. Ante tal alternativa, as grandes maiorias das sociedades modernas souberam escolher de forma bastante clara. Os seguros vencem a evidência este princípio encerra o destino de toda a filosofia no mundo técnico. (id., ibid., p. 103)
\end{abstract}

A noção sloterdijkiana de pós-história é menos um conceito hegel-kojeveano ${ }^{76}$ de filosofia da história do que um conceito da técnica dos seguros. Nas sociedades asseguradas, tudo o que é verdadeiramente "arriscado está de fato excluído de compensação em caso de dano" (id., ibid.). E o que é verdadeiramente arriscado? São os velhos atos históricos, tais como "criações de religiões, cruzadas, revoluções, guerras de liberdade, lutas de classe e promessas atinentes" (id., ibid.). Essas ações não são admitidas, pois seu risco não é segurável.

Mas é nas sociedades asseguradas do tédio que cresce a retórica do jovem "pret-àrevolter" (id., ibid., p. 187) e a semântica da "inovação e diferença” (id., 2007, p. 37) domina um mundo onde "tudo pode ser revolucionário porque as revoluções à antiga

\footnotetext{
${ }^{76}$ A discussão destes autores e sua retomada por Fukuyama está em $O$ sol e a morte, p. 35-40.
} 
são impossíveis neste mundo denso" (id., ibid.). Passa a ser revolucionário não determinar o sexo de uma criança, por exemplo, num mundo em que a ordem das competências já emoldurou o destino de qualquer necessidade humana. Louva-se o "acontecimento" e a experiência da "diferença" num mundo em que "quem tem dor de dentes vai ao dentista, quem tem dores nos pés vai ao ortopedista, quem tem angústia existencial vai ver um guru [...] e quem não se acomoda à vida normal [...] viaja para Ibiza" (id., ibid.).

Não se trata de esgotar a discussão sloterdijkiana da global age, mas de ter sempre em mente que os seus relatos da era histórica preparam a compreensão do nosso atual lugar epocal. Vale dizer que a uma época de expedições e conquistas segue a era conquistada. A expedição europeia se deu sob o primado das expedições e das idas nas quais a exterioridade do exterior era diminuída através da tomada de registro e da captação por imagem. Quem faz um mapa ou o desenho de uma planta dá ao "estranho" uma medida "suportável para o europeu médio" (id., 2008b, p. 106). A época moderna é nesse sentido a época dos Descobrimentos -

um plural que designa de fato um processo singular, o hiperacontecimento autenticamente histórico constituído pela circumnavegação e captação da terra, designa pois a encarnação de práticas pelas quais o desconhecido se transforma em conhecido, o não representado em representado (id., ibid.).

Nos termos heideggerianos de uma história epocal da verdade, a modernidade é o assalto progressivo e organizado ao dissimulado. O manifesto não irrompe por si mesmo como physis, como epifania automostrante, nem é o resultado da criação de um Deus transcendente. $\mathrm{O}$ manifesto depende da intervenção humana. $\mathrm{O}$ assalto organizado ao oculto e à latência é o acontecimento central da era moderna, ${ }^{77}$ e a globalização terrestre levada a cabo pelos descobridores consuma esse processo de captar e registrar a fim de que qualquer coisa descoberta permaneça conhecida. Se no início se (des)afastou uma terra imensa, a sensação que se tem hoje é de uma terra pequenina cujas reservas são esgotáveis.

A marcha dos mapas "repete em nível dos media visuais da globalização o processo de conquista do mundo como imagem sublinhado por Heidegger" (id., ibid., p. 110). Fazer um mapa do lugar e dar-lhe um nome equivalia assim a ter um título

\footnotetext{
${ }^{77}$ Como foi visto, Esferas III analisa a aceleração desse processo de ataque à latência durante os séculos XX e XXI. Ao menos duzentas páginas dessa obra estão focadas nesta questão.
} 
jurídico de propriedade. Na discussão que Sloterdijk faz de O Nomos da terra, de Carl Schmitt, está claro que para os europeus não se tratava de um direito de visitar outros povos, mas que os outros povos achados equivaliam no direito marítimo a peixes-à-solta que têm caça livre e são de quem os encontra. Aqueles que seriam considerados ladrões em termos judiciarizados e pós-históricos eram, no contexto das agressões históricas, heróis e missionários (id., ibid., p. 129), e nesse sentido, Sloterdijk escreve que a globalização terrestre é o "crime que só se pode cometer uma vez" e ele já foi cometido apesar da "crescente tribunalização" atual da história passada (id., ibid., p. 130).

A legitimidade da dominação pelo mero ter achado não é uma fantasia legitimadora anacrônica de Schmitt, mas é, de fato, o modo como os acontecimentos estavam costurados. Os conquistadores eram legítimos porque eram exportadores das conquistas civilizacionais europeias. Aquele que faz o mapa "apresenta-se como se o direito cultural, histórico, jurídico e político estivesse do seu lado" (id., ibid., p. 114). Os habitantes das terras distantes não eram considerados seus proprietários, mas meros achados coloniais, assim como representantes da fauna e da flora, que se pode caçar e colecionar à vontade. Quanto ao "desafastamento semântico do mundo", Sloterdijk mostra que os europeus "clonam semanticamente o seu próprio mundo" (id., ibid., p. 115 e 117) para se apropriarem de lugares estrangeiros, mas quando e enquanto no estrangeiro e na exterioridade, dedicam-se livremente à prática da crueldade, e o lema síntese do humor pirata é "destruo, logo existo" (id., ibid., p. 122). O extremo da crueldade entre humanos acontecia nos mares, e a morte de deus põe em cena as formas empresariais do ateísmo como a pirataria e o tráfico negreiro:

quando deus está morto - ou quando não está a olhar, no território sem Estado, no navio sem capelão, nos mares sem lei, fora das zonas de respeito convencionado, no espaço sem testemunhas, no vazio moral beyond the line - o inconcebível é efetivamente possível (id., ibid., p. $123)$.

A desinibição libertária e anárquica do pirata é fonte de angústia para o homem da terra firme que nunca sabe bem o que esperar de um anarco-marítimo.

Segundo Sloteredijk, foi Herman Melville em Moby Dick quem melhor pensou a exterioridade radical da superfície terrestre e o homem despencado no exterior, fora de qualquer inclusão em recipientes imunológicos participativos. O marinheiro possesso não tem por aliado um espírito de proximidade nem um deus nas alturas, mas uma divindade do lá-fora e do inferior. A baleia encarna uma potência que se enrola sobre si 
mesma nas "profundidades inquietantes do mar" (id., ibid., p. 125) e o seu branco, a brancura desfaz qualquer sentimento de intimidade, de pátria e de chegada. Melville dizia que o branco é "o ateísmo incolor, multicolor diante do qual nos encolhemos" (apud SLOTERDIJK, 2008b, p. 125). O branco da baleia é como o grande vazio também branco da Via láctea. O lá-fora-exterior e indiferente destrói aquele ente, o ente humano que só pode existir incluindo-se em comunidades de não indiferença. Se o inferno é o exterior, o inferno branco de cujo primado se parte, a questão é saber se as pessoas logram ou não construir suas relações mútuas em receptáculos autogerados em que o não indiferente vença o indiferente.

É preciso compreender como os europeus e seus descendentes tiveram sucesso no assalto ao branco planetário. O exterior não seria atravessável se os europeus não carregassem consigo e preservassem nas incursões pelo distante as condições endoesféricas mínimas. A história dos mistérios esferológicos do êxito da globalização avançada é a história dos invólucros e recipientes, que os viajantes levavam consigo como abrigos autocarregados nas longas travessias. Os europeus souberam exportar baldaquinos e tendas que são as "simbolizações portáteis do céu de que os viajantes se podiam apropriar, mesmo no exterior, como “céus para nós"' (SLOTERDIJK, 2008b, p. 131). Levar o espaço próprio ao mais remoto foi o que assegurou aos europeus a possibilidade de transformar o exterior em área vivível pelo invasor. O primeiro baldaquino é a poética do porão ou a mitologia naval: um navio, mais do que um carro atual, é um ninho mobilizado ou casa absoluta. O navio é a "contradição resolvida" (id., ibid., p. 133) do estar-em-casa e da evasão, do habitat e da aventura. O navio cruza o alto mar como a bala do projétil, mas possibilita no seu interior relações simbióticas. "O veículo é sentido como um ventre que encerra uma ninhada de recém-nascidos" (id., ibid.). O caráter aterrador do branco exterior é ultrapassado pelo aninhamento no interior do barco e este, como uma grande mãe dirigível, leva suas tripulações ao longe sem que elas percam o domicílio, involucradas que estão naquela pátria-portátil.

Em $O$ sol e a morte, em resposta a Hans-Jürgen Heinrichs sobre a função baldaquino, Sloterdijk afirma que mesmo um contemporâneo pode reconstituir experimentalmente o domínio sobre o exterior oceânico, pois nós "continuamos a poder sentir o que significava a estadia de um passageiro num barco e, mais ainda, de um navegador que sente o meio de transporte como uma extensão corporal enquanto se vincula imaginariamente ao barco" (id., 2007, p. 194). Em termos esferológicos, o navio é o abrigo de um interior, cruzando o elemento invivível. 
O segundo baldaquino da globalização é a religião cristã e seu sistema de seguros metafísico. Nesse caso, o horror do exterior e de uma "morte sem túmulo" (MELVILLE apud SLOTERDIJK, 2008b, p. 135, n. 150) era compensada pela presença a bordo do "perito do extremo" (SLOTERDIJK, 2008b, p. 135) como o capelão que, no barco, dava seguimento às rotinas metafísicas da terra natal. A virgem Maria parecia também como a grande protetora e mãe dos marinheiros e, embora, já por essa época, o céu metafísico estivesse sendo despedaçado pelos cosmólogos, a virgem ainda conseguia amparar "os seus no invólucro de um útero mundial" (id., ibid., p. 136). E no que diz respeito à conquista das terras virgens, a "benção pontificial" aos avanços portugueses e espanhóis era praticamente incondicional. Roma era uma espécie de "assistente sem poder" (id., ibid.) dos estados colonizados e a extensão da missão neoapostólica nas terras virgens protegia o colonialismo. Já no campo das missões protestantes, o amálgama com "funções nacional-coloniais" (id., ibid., p. 137) era ainda mais claro.

Quanto ao terceiro baldaquino, o título de vice-rei esclarece psicopoliticamente o núcleo da conquista, pois é através do vice-rei que o rei se faz presente ainda que ele não visite em carne e osso as suas colônias. Esse título evidencia que o conquistador e chefe de expedição sabia a quem se destinava seus sucessos e pilhagens. Através do baldaquino da majestade, o raio de luz saía do centro e ia até a derradeira colônia e regressava ao centro. Se os vice-reis traziam novas conquistas ao rei, os jesuítas, como tropas de elite do papa, arrebanhavam novos fiéis à Igreja. Sloterdijk considera que os jesuítas são os antecipadores da internet, pois eles desde o século XVI cobriam o "globo com uma rede de orações pelo papa e de atenções para com Roma - uma internet da mais fervorosa obediência, nascida de terras longínquas e fiéis ao centro". A imunidade moderna da telecomunicação global, hoje info-via palaciana, foi "prefigurada na teleoração pelo papa" (id., ibid., p. 140).

Mas mesmo quem não era fiel ao rei nem missionário do papa tinha boas razões para embarcar de um modo laico e com os olhos voltados para a captura do mundo. Eram os agentes das "ciências empíricas europeias" (id., ibid., p. 142). Com os homens jogados no exterior da crosta terrestre, as ciências humanas como a geografia e a antropologia entram em cena e com elas os seus agentes, os investigadores europeus. Esses, mesmo que situados em ilhas remotas, sentiam-se como observadores e registradores de descobertas agora pertencentes ao âmbito inteiro da humanidade instruída. Todo tipo de observador, desde o autor dos relatos de viagem ou de um "romance exótico" até um Charles Darwin e um Alexander von Humboldt, toma parte 
da escrita do "grande livro da teoria neoeuropeia" (id., ibid., p. 143). É esse livro fantástico que funciona como quarto baldaquino da globalização. Ele não existiu empiricamente por muito tempo, até que se converteu em meados do século XVIII em uma publicação real: os dezessete volumes de texto e onze de ilustrações da Enciclopédia. Nesse grande livro das ciências, o "negro das letras da tipografia celebra também a vitória sobre o branco" (id., ibid., p. 144).

A última função de baldaquino durante a globalização terrestre foi exercida pelos tradutores. Na situação caótica de encontro com mais de cinco mil línguas havia duas alternativas: ou a imposição da língua europeia dos senhores ou a penetração nas outras línguas por meio de traduções. Para Sloterdijk, os dois processos ocorreram, embora o certo é que "a língua europeia dos senhores é que recobriu as línguas locais, não foram as línguas locais que absorveram as dos colonizadores" (id., ibid., p. 145).

\section{ADENDO IV}

\section{Sobre normalidade, situação-limite e decisão}

O privilégio concedido à exceção e ao excepcional está no coração do debate filosófico alemão dos anos 1930, como o atestam Heidegger e Carl Schmitt. Há nesses autores todo um vocabulário centrado na importância da situação-limite, do caso crítico e da decisão. Em ambos os autores, a predileção pelo instituinte e pelo emergente, em detrimento do instituído e do sedimentado, salta aos olhos. Há que enxergar o abismo infundado a sustentar a normalidade cotidiana, este, sim, muito mais decisivo e interessante que o caso normal.

No caso de Heidegger, nota-se que, embora sua analítica da existência parta da cotidianidade e da significatividade intramundana, essas passam a ter um caráter de encobrimento e de esquecimento quando "vistas" da "situação-limite"78 experimentada na angústia.

\footnotetext{
${ }^{78}$ É o próprio Heidegger que se utiliza do termo "situação-limite": tal possibilidade "revela que esse ente está lançado na indeterminação de sua 'situação-limite', em cuja decisão o Daisen adquire seu poder-ser total em sentido próprio [...]. Essa angústia originária, porém, aspira a dispor-se à decisão resoluta. Ela varre todo encobrimento acerca do abandono do Dasein" (HEIDEGGER, Ser e tempo, \$62, 2006, p. 391).
} 
Que se retome sucintamente a analítica de Heidegger no Ser e tempo: de início, diz ele, o Dasein se toma e se compreende a partir da rede de conexões de significatividade intramundana. É a partir dessa rede de significação que ele ganha um ser. Vale dizer: é engenheiro, filho de Deus ou do macaco, professor de filosofia, sacerdote, casado ou solteiro etc. Compreende-se, portanto, tanto em função do que faz e "anda fazendo" quanto das remessas intramundanas de sentido que calibram e regulam sua época e o mundo no qual foi jogado. É isto que outorga um ser, uma certa espessura, ao que Heidegger denominava o ens realissimum. A afetividade e a compreensibilidade média regulam a tríplice abertura do Dasein. Tríplice porque é uma abertura tanto para o outro quanto para o ente e para si mesmo. Nesse sentido, a própria autocompreensão é inteiramente pública e depende das calibragens hermenêuticas prévias. Essa dependência é índice da finitude e do caráter histórico do Dasein. Entretanto, quando sobrevém esta disposição de ânimo fundamental que é a angústia (Angst), tudo aquilo que dava fisionomia e assegurava a "realidade" do realissimum Dasein se retrai e perde sentido. Nesse momento, o si mesmo (Selbst) se "desrealiza", pois aquilo a partir de onde (ou a partir de quê) o sujeito se delineava se evapora. Não se tomando mais a partir da referencialização outorgada pelas remissões e pelas redes de conformação mundanas, o sujeito não encontra mais nenhuma espessura, nenhum fundamento. Seria um erro supor que nessa "reflexividade" propiciada pela angústia - e a angústia tem um papel metódico fundamental dentro de Ser e tempo, exatamente por que é apenas ela que assegura a possibilidade de uma certa reflexão ou de um dobrar-se do Dasein sobre si mesmo - o sujeito encontraria algo de sólido, sua verdadeira natureza ou a munição de um repertório de transcendentais. Não; sabe-se apenas que o Dasein é fundamento de uma nadidade e que não há nada inscrito nele. Demitido do fundamento, deve então, por meio de uma decisão, encarregar-se dele e instaurar o "algo" que lhe falta.

A angústia, ao desconfigurar o arranjo hermenêutico da mundanidade dada e reabrir a erupção original do mundo em sua nudez, reinaugura o momento instituinte que autoriza tanto uma ratificação da métrica do sentido dado quanto uma eleição/decisão modificadora. ${ }^{79}$ Sou um filho de Deus, do macaco ou de pai e mãe?

\footnotetext{
${ }^{79}$ Karl Löwith, aluno de Heidegger na época em que este cunhou essas noções, conta que os alunos do famoso professor ao saírem da aula brincavam, dizendo: "Estou decidido, só não sei decidido a quê". Essa anedota mostra que Heidegger não colocava um conteúdo na decisão. Esse conteúdo, entretanto, passou a ser o Führer a partir do discurso do reitorado feito em 1933 (cf. HEIDEGGER, 1982, p. 22). Isso mostra
} 
Com qual sentido vou cobrir a pele do ente ex-posto que sou? Tanto a mobilidade histórica emana da decisão quanto a ulterior saída heideggeriana para fora da história acontecida da metafísica - algo ainda não concebido em Ser e tempo - depende de uma nova espécie de decisão: esta, sim, inaudita e de ruptura com o sentido em favor de uma hesitação piedosa diante do surgimento da presença. ${ }^{80}$

A paixão pelo extremo e pelo caso crítico, tanto no caso de Heidegger como no exemplo que será visto de Schmitt, contrasta com a importância esferológica do confiável, do estável e da continuidade. É óbvio que o pensamento das esferas tem ferramentas para tematizar as rupturas, os traumas e as perdas de mundo, mas não cai na ingenuidade de hiperdignificar aquilo que é causador de desconfiança e quebra. Já nos primeiros recintos antroposféricos, o animal que se refinava ao se afastar da natureza era atento e cheio de cuidados para estabilizar e proteger o receptáculo. O cuidado de si do primata dissidente, que se tornou lárico, é simultaneamente um cuidado com as regras do termotopo, do fonotopo, do uterotopo e do quirotopo. A estabilização do interior do recinto é fundamental: sem ela, não há comodidade ou bem-estar. O ser humano é cuidadoso, não porque antecipe sua própria desaparição como no teorema de Heidegger, mas o é porque antecipa as condições da manutenção do conforto. Para aquele que se exilou da pobreza do ambiente e vive em um receptáculo que concede inclusive o luxo de ficar atrasado e manter traços infantis, o principal é o cuidado e a atenção com o próprio recinto.

O quirotopo, o termotopo, o tanatotopo ${ }^{81}$ todos são dimensões zeladas pelo animal que já se encontra no mundo em uma comunidade civilizadora. E conforme foi visto no capítulo 2, a climatização simbólica e afetiva do espaço interior é também cuidado de si, desde que se entenda que o cuidado de si é um cuidado de todo o grupo com o receptáculo. É óbvio que se pode objetar que as culturas, no começo, eram muito mais neofóbicas e carentes de estabilização do que as culturas neofílicas como a da modernidade. ${ }^{82}$ Isso é correto, mas o que se procura mostrar aqui na discussão com

que o filósofo da Floresta Negra se apropriou dos seus próprios termos filosóficos para colocá-los a serviço da revolução.

${ }^{80}$ Sobre o segundo tipo de decisão cf. Contribuições à filosofia (HEIDEGGER, 2015).

${ }^{81}$ Neste trabalho, não se avançou muito na análise do tanatotopo, além das breves considerações sobre a morte do outro no capítulo 2. O estudo dessa dimensão da antroposfera em Esferas III parte da constatação de que a "ilha humana" é visitada pelos mortos, pois seres humanos são aqueles que têm mortos atrás de si.

82 A modernidade é caracterizada como neofílica, principalmente no livro Deves transformar tua vida, bem como experimento antigenealógico no livro Die schrecklichen Kinder der Neuzeit [os filhos terríveis da modernidade], editado na França com o título Après Nous Le Déluge [depois de nós o dilúvio]. 
Heidegger é que para os seres humanos não há outro lugar a não ser o mundo e que este estar-no-mundo não é o assombro do hóspede transiente tomado pelo hino do agradecimento (nesse caso, é o ser que está em casa!). No doméstico e costumeiro, a linguagem não celebra o ser, mas transfere o semelhante no dessemelhante e, metaforizando, apazigua o inquietante. Assim, no confiável, é o homem que está em casa. Na extremidade, a linguagem quebra e a casa se desfaz. Pode-se dizer, resumidamente, que, se Heidegger é o pensador da ek-stase, do estar suspenso no exterior, Sloterdijk pensa também a en-stase. ${ }^{83}$

Quanto a Schmitt, trata-se de mostrar que a decisão que constitui a normalidade de uma certa ordem não é dedutível desta própria ordem, e quem pretenda entender a fundamentação última desta deverá transcender sua lógica interna e abrir-se ao que lhe é alheio. Imagine-se que alguém receba o comando de entregar sua casa. Como posso diferenciar o comando arbitrário de um ladrão da ordem de um oficial de justiça, ambas idênticas do ponto de vista espaço-temporal? Do ponto de vista de uma teoria jurídica normativa, a resposta reside em que a ordem do ladrão não passa de um dever-ser subjetivo, de um mero ato de vontade, pois não haveria normas superiores que "jurisdicizassem" a atividade do bandido; ao contrário, a ordem do oficial de justiça tem um sentido objetivo e guarda uma significação jurídica, pois está fundada numa norma superior que objetiva o comando do oficial, na mesma medida em que converte aquele indivíduo num órgão do Estado: o fundamento da validade de uma norma é uma norma superior, e assim sucessivamente até o ponto de parada que é a norma fundamental (Grundnorm). Mas se poderia então perguntar: em que caso e a partir de que momento pode o cientista do direito pressupor essa norma, "que é logicamente indispensável para a fundamentação da validade objetiva das normas jurídicas"? (KELSEN, 1976, p. 283) E a resposta é: o jurista pode pensá-la apenas se a Constituição, no sentido jurídicopositivo, e a ordem coercitiva por ela inaugurada forem globalmente eficazes. Apenas quando já se tiver abandonado o statu nascenti, de anomia, e quando já se estiver inscrito num ordenamento eficaz, com poder vinculante de fato. Isso significa que a normalidade da situação, como diz Schmitt, constitui um pressuposto fundamental do normativismo - falar em norma sem normalidade seria um absurdo completo. ${ }^{84}$ Assim, o cientista do direito só pode pressupor aquela norma, que é fundamento da validade, se

\footnotetext{
${ }^{83}$ Sobre este tema cf. Palácio de cristal (SLOTERDIJK, 2008b, p. 213).

84 “Toda norma pressupõe uma situação normal”, diz Schmitt no Conceito do político.
} 
ele já não está dentro de uma situação abnorme (de exceção), mas submetido à efetividade de um ordenamento que vigora com um mínimo de eficácia e estabilidade.

Quanto a esse primeiro ponto, que se poderia denominar de "pressuposto da normalidade", Schmitt diz:

A normalidade da situação concreta, regulada pela norma, e do tipo concreto por esta pressuposto não é portanto somente um pressuposto externo da norma, que não deveria ser tomado em consideração pela ciência do Direito, mas um caráter juridicamente essencial da validade das normas e consequentemente uma definição normativa da própria norma. Uma norma pura, não correlata a uma situação e a um tipo, seria qualquer coisa de juridicamente inexistente. (SCHMITT, 1972, p. 260)

A normalidade da ordem jurídico-política, entretanto, não pode se assentar sobre si mesma e depende de uma gênese que a ultrapassa. Isso fica evidente quando se examina mais de perto a referida norma fundamental sobre a qual se assenta a validade do ordenamento jurídico. Para Kelsen, a ciência jurídica, enquanto ciência normativa, deve unicamente descrever as normas por meio de proposições de dever-ser, deixando de lado tudo que é do âmbito do ser. O princípio metódico da pureza (KELSEN, 1976, p. 17 e 18) exige que ele se ocupe exclusivamente com normas e se atenha ao plano deôntico, abandonando qualquer aspecto ôntico, como a questão da eficácia e do cumprimento das mesmas. ${ }^{85}$ Mais uma vez, esse difícil problema, como nota Schmitt, vai alojar-se na norma fundamental, pois ela, no sentido transcendental, só pode ser pressuposta se a Constituição (em sentido jurídico-positivo) for minimamente eficaz. Mas o que significa dizer que uma norma primeira (uma constituição) tem de ser eficaz? Significa que ela tem de ser poderosa, isto é, que ela tem de estar ancorada numa Rechtsmacht, num ato criador de direito. Essa decisão instauradora do direito, no entanto, é ela mesma algo não jurídico (é da ordem do ser), algo que apenas retrospectivamente, se o que for ali instaurado durar e estabilizar-se, pode ganhar uma significação propriamente jurídica. Ex nihilo nascitur ordo: é esse momento excepcional que produz a regra. Ele é não regrado e, apenas mantendo-se, pode, $a$ posteriori, receber um revestimento jurídico.

\footnotetext{
$\overline{85}$ Essa exigência, segundo Schmitt, "constitui um difícil e insolúvel problema lógico, uma vez que o pensamento normativista, quanto mais é puro, tanto mais conduz a uma fratura sempre mais drástica entre norma e realidade, entre dever e ser, entre regra e comportamento concreto. Todas as normas válidas são, a fim de que valham, naturalmente sempre 'em ordem'; a 'desordem' da situação concreta não interessa ao normativista que, verdadeiramente, está interessado só nas normas" (SCHMITT, 1972, p. 250).
} 
Na teologia política de Schmitt, a exceção é o mais interessante, o caso normal e a regra não dizem nada, e é na exceção que a potência da vida real quebra o enrijecido por sedimentações repetidas. A fundamentação da validade da ordem não é imanente a ela e depende de uma "decisão originária [...] não mais fundamentável” (FLICKINGER, 1992, p. 21). Contra a tese de uma legitimação legal racional imanente, Schmitt reedita a soberania de uma decisão originária criadora de ordem. Ele transpõe o conceito teológico do lógos divino para o plano político. Essa operação schmittiana cujo legado se estende até o pensamento de Giorgio Aganbem é objeto da crítica sloterdijkiana. O diálogo de Sloterdijk com Schmitt consiste em redefinir o estado de exceção. Este não evoca mais a sublime suspensão da normalidade e a força excepcional que funda a regra, mas uma situação natural do tipo "tudo-ou-nada" (SLOTERDIJK, 2009a, p. 320). Situação crítica é aquele na qual o perigo de morte é "supremamente real" (id., ibid., p. 321) e desencadeia a decisão de fuga ou ataque. A interrupção da normalidade não deve ser pensada com conceitos teológicos laicizados, pois ela é uma situação biologicamente comum: até os animais realizam o veredito do caso extremo e a liberação da adrenalina é a prova ontológica deste. Afastando-se de Schmitt e da ideia da interrupção milagrosa do normal, de que "falam os teólogos e estetas do sublime" (id., ibid.), Sloterdijk vai pensar a situação-limite a partir da noção de stress de Heiner Mühlmann. Stress é aquilo em torno do que um grupo se configura. Há assim uma fase pré-stress, uma de stress e outra pós-stress. $^{86}$

$\mathrm{Na}$ fase pré-stress "os grupos se desenvolvem formando unidades cooperativas com fortes desníveis dentro-fora, sobretudo [...] mediante comunicações autoexortadoras, autoedificantes, autoengradecedoras, que Mühlmann resume como intimações-insider (Insider-Injunktionen) (id., ibid., p. 321-322). Basta examinar detidamente o fonotopo, o uterotopo e o termotopo para perceber que as ilhas humanas ou cápsulas culturais discriminam positivamente o "grupo nós" (id., ibid., p. 322). A maioria das culturas, exceção feita àquelas de alto grau civilizacional, é não simpática e se comporta de modo invejoso, agressivo e paranoico. Sloterdijk recorre aqui novamente a Schmitt por considerar que este aspecto do pré-stress foi conceitualizado na década de 1930 por "pensadores decisionistas de direita" (id., ibid.). A distinção

\footnotetext{
${ }^{86}$ Esta exposição encontra-se em Esferas III p. 321-325. Aqui se destaca apenas a discussão com Carl Schmitt.
} 
schmittiana amigo e inimigo ${ }^{87}$ consagra a interparanoia e reza que a solidariedade do grupo depende do "desdém coletivo pelo inimigo" (id., ibid.). Contra o heroísmo paranoico, a terapêutica filo-moderna de Sloterdijk consiste em apostar nos processos explicativos: assim como a explicitação da maternidade possibilita a substituição das mães por outros agentes do mimo, a explicitação das culturas possibilita a crítica do heroísmo e evidencia "os modos do funcionamento do nós paranoico" (id., ibid., p. 323).

É ainda sob a rubrica do heroísmo e do desdém pelos ânimos modernos da leveza que Sloterdijk coloca lado a lado a importância dada por Schmitt ao caso-crítico na conformação do mundo jurídico e a paixão heideggeriana pela situação-limite da angústia, esta exceção privada, e o que ela revela sobre a conformação do mundo em geral. Em ambos, opta-se pela concentração e pelo peso, enquanto que as condições modernas apontam para a dispersão e a indecisão. ${ }^{88} \mathrm{~A}$ diminuição do peso do mundo é para Sloterdijk o fenômeno mais marcante do século XX (principalmente nos últimos oitenta anos) e o seu grande impensado até hoje. Tanto Heidegger quanto Carl Schmitt e Gehlen poderia ser acrescentado - sabiam que epocalmente a dispersão seria dominante. O que caracteriza esses autores como conservadores é a ideia de que somente a existência enformada pelo caso crítico e pela experiência do extremo é séria. A existência dispensada da necessidade vive tão apenas uma deriva banal. Concordar com isso não é participar do preconceito do velho heroísmo europeu? Sloterdijk acredita que sim. Doravante o caso crítico é assunto de autoeleição arbitrária, pois o programa heroico nas sociedades de consumo "funciona no vazio" (id., ibid., p. 549).

\subsection{O palácio: diagnóstico da atualidade}

\footnotetext{
87 Schmitt escreve que "a distinção especificamente política a que podem reportar-se as ações e os motivos políticos é a discriminação entre amigo e inimigo" (SCHMITT, 1992, p. 51).

${ }^{88}$ São sete os elementos que Sloterdijk elenca como responsáveis pelo tornar-se leve da vida na sociedade abundante (Affluent Society): “a investigação científica incessante, a invenção técnica jamais desalentada, o crescente atrativo da forma de vida empresarial, a expansão constante de um sistema de saúde baseado na previdência social, a inclusão de um público cada vez mais numeroso de clientes no consumo econômico e cultural, assim como a consolidação da imunidade profissional e jurídica dos indivíduos mediante um direito trabalhista elaborado, sobretudo as mulheres que exercem uma profissão e, finalmente, a instauração de um sistema de seguros amplamente especializado, inclusive onipresente" (SLOTERDIJK, 2009a, p. 515).
} 
Finda a era da conquista histórica, passados quinhentos anos das viagens de Colombo, a

Terra circum-navegada, descoberta, representada, ocupada e utilizada apresenta-se como um corpo anichado num denso tecido de movimentos de tráfico e de rotinas telecomunicativas. Os invólucros virtuais substituíram o etéreo céu imaginário; os sistemas radioeletrônicos permitem alijar efetivamente as distâncias do pensamento, nos centros do poder e de consumo. Os global-players vivem num mundo sem distâncias. Do ponto de vista aeronáutico, a Terra reduz-se quando muito a cinquenta horas de voo num só jato. Nos voos orbitais dos satélites e da estação MIR, e, mais recentemente nas rotações entorno do globo ISS, a estação espacial internacional, tornaram-se habituais unidades de tempo de cerca de noventa minutos. Para as mensagens rádio e luminosas, a Terra reduziu-se praticamente a um ponto imóvel - está em rotação, como globo temporalmente compacto, num feltro eletrônico que a envolve como uma segunda atmosfera (id., 2008b, p. 151).

A consumação da globalização é a própria autojustificação do processo. O fato da globalização fala tão alto que ela é um destino que prescinde de legitimação. Tudo o que foi desencadeado no século XVI, o XX aperfeiçoou: o movimento do dinheiro pela superfície terrestre já não faz estadias invisíveis, mas se tornou foco, "um lugar de onde se vê que se é visto" (id., ibid.). As cidades todas se tornaram portuárias e a informação transita pelas infovias, formando correntes no mar de dados. Através dos media, a globalização "comunica permanentemente" (id., 2004a, p. 849) o que acontece e avança à revelia de qualquer alternativa. Indiferente a e independente de toda filosofia e outras formas de expressão e de teoria, a globalização monologa apenas consigo mesma e a análise da "situação estratégica tomou lugar da crítica" (id., 2008b, p. 152). Com a falência da crítica, o curso do mundo torna-se uma espécie de "ato de Deus" feito através de atos humanos. A globalização como destino implica que não há mais "vontade de abstenção, por mais universal [...] que possa deter a sua progressão" (id., ibid.). Já não há como recuar do fato de que "demos a volta à Terra e os povos ou as civilizações que nela vivem encontram-se numa obrigação de comunicação" (id., ibid.). Para Sloterdijk, uma teoria da idade contemporânea tem que partir necessariamente da globalização consumada. Já não há mais como os povos viverem separadamente em suas endosferas e círculos linguísticos. A revolução moderna, ao encurtar e suprimir a distância, obrigará a todos a viver no mesmo planeta, o "astro dos que não estão escondidos" (id., ibid.). 
O fato de já não poderem mais se esconder ou ignorar uns aos outros como era a regra geral até bem pouco tempo, pois os seres humanos sempre ignoraram a maioria dos outros alojados fora do seu próprio contentor ético, não significa que doravante se efetue uma abertura de todos a todos. O pouco interesse que o ser humano nutre pelo outro fica cada vez mais claro no "curso da interconexão mundial" (id., 2004a, p. 850). A globalização inverte a regra antropológica segundo a qual o desinteresse pelo estranho e o concorrente constituem a situação normal. Ela obriga o ser que gosta de ignorar tudo o que não é inerente ao seu próprio contentor a não virar as costas e ter de se haver constantemente com o afastado e o concorrente. Não há mais como fugir da cronificação do contato e do dia permanente do mercado mundial: o mundo globalizado é sincrônico. A sincronização é uma situação na qual os seres, todos eles, estão

implicados à distância, humilhados, dilacerados, vinculados e supersolicitados - focos de uma ilusão vital, endereços do capital, pontos no espaço homogêneo, aos quais se regressa e que a si próprios regressam - mais vistos do que vendo, mais captados do que captantes, mais atingidos do que atingentes" (id., 2008b, p. 159).

Essa situação é resultado das viagens colonizantes e, posteriormente, pelas viagens em sentido contrário. Na globalização consumada, os riscos comuns e as ameaças sofridas comumente são a base "de todos os mecanismos de consenso e de cooperação em grande escala" (id., ibid., p. 155). É a era da política temática, da agenda e dos riscos generalizados. E os homens, nessa nova situação, são os obsoletos, os que ficaram ultrapassados, "as vítimas do eu como desvantagem ligada ao local” (id., ibid., p. 159).

Outro aspecto da globalização é a diminuição cada vez maior da importância do estado nação e o surgimento de novas determinações do eu e do lugar. O eu multilocal já é uma tendência crescente e, a exemplo do povo judeu, que viveu por muito tempo sem um território, o eu sem lugar já não se soletra a partir dos "contentores maciços, étnicos e nacionais" (id., ibid., p. 165): o eu sem lugar se desacopla do desenho imunitário dos receptáculos de paredes grossas para formas de vida radicalmente individualistas e desnacionalizadas. O coletivo nacional e seu conforto doméstico dão lugar a uma desconvergência do eu e do lugar e os indivíduos flexibilizados e individualizados, devotados ao "cuidado de si biológico, psicotécnico e religioide" (id., ibid., p. 166) buscam seu "ótimo imunológico" (id., ibid., p. 167) em técnicas novas como a dietética e biotécnica. Do ponto de vista institucional, são os "seguros privados 
e os fundos de pensão" (id., ibid.) que constituem o núcleo do desenho imunológico individualista. Outra consequência desse estado de coisas é a desaparição do homem poliexpressivo e aberto receptivamente ao mundo para dar lugar ao especialista cujo recorte estrito define o contato que terá com ele.

Compreender a globalização consumada é entender do palácio de cristal e das situações saturadas e cristalizadas. Outro nome para isto é pós-história. ${ }^{89}$ Quem vive em uma grande cidade, onde há muito tempo não é possível edificar alguma coisa nova, sabe o que significa atingir um "patamar de cristalização, no qual [...] se procede a renovações, adaptações e reconstruções" (id., ibid., p. 171). A cristalização permite intensificação e otimização, mas proíbe a irrupção do elemento histórico. Nesse sentido, os dois principais diagnosticadores do tédio pós-histórico são Dostoiévski e Heidegger. O primeiro visitou Londres em 1862 e ficou impressionado com o edifício palaciano de uma Exposição Universal. Ele percebeu que, na forma fechada deste palácio, no seu caráter de estufa artificial, revelava-se o segredo da platitude pós-histórica: se a história real acontece ao ar livre, o desejo de uma paz eterna só se satisfaz quando a totalidade da vida social é integrada em um "habitáculo protetor" (id., ibid., p. 186). Dostoiévski conectou o impacto negativo de sua visita londrina ao Crystal Palace com a irritação que sentiu ao ler o livro de Tchernichevsky Que fazer?, de 1863, cujo conteúdo saúda a vinda de um novo homem que "uma vez consumada a solução técnica da questão social, viveria entre os seus semelhantes num palácio de vidro e de metal [...] concebido como um edifício de luxo com ar-condicionado, no qual deveria reinar uma eterna primavera do consenso" (id., ibid., p. 185). O autor das Notas do subterrâneo percebeu que, dentro desta estufa artificial, os acontecimentos históricos quentes davam lugar a meras notícias historiológicas domésticas. Percebeu também que o frisson hedonista seria o estado de ânimo fundamental no novo mundo do consumo, e a divisa otimista, segundo a qual "o conforto não parará de fluir e de crescer" (id., ibid., p. 186) se converteria no único chamado audível.

Para Dostoiévski, entretanto, esta situação de relaxamento pós-histórico, o niilismo da transparência, levaria a uma intensificação do puro mal, uma vez que este apenas "no tédio pós-histórico (skuka) se pode cristalizar sob a sua forma quintaessencial: purificado de todos os subterfúgios, passa a ser manifesto - para surpresa talvez dos ingênuos - que o mal detém a qualidade do puro capricho" (id., ibid., p. 187).

\footnotetext{
${ }^{89}$ O início da pós-história pode ser datado em 1945 (fim da Segunda Guerra Mundial) ou em 1974 (data do final do colonialismo).
} 
Se nas situações históricas de agressão e de violência o mal está bem empregado, no novo contexto pós-histórico, ele fica desempregado, e passa a agir arbitrariamente sem nenhum motivo. Lido na chave da psicologia dostoievskiana, o crime dos jovens que queimaram o índio Galdino na cidade de Brasília no final da década de 1990 mostra que no tédio pós-histórico tanto o que é rejeitado quanto o que é apreciado se decide num indiferente lance de dados, como se o fortuito e o lotérico tudo comandassem.

Também a fenomenologia heideggeriana do Dasein entediado elaborada no curso de 1929-1930 Os conceitos fundamentais da metafísica é, conforme esclarece Sloterdijk, a instrução de um "filósofo punk" (id., ibid., p. 188) sobre como arrebentar o palácio de vidro e reabrir a relação do indivíduo com o exterior e o monstruoso. Se no interior do palácio da tecnosfera tudo já está decidido, e a existência dominada vive na despossessão de si mesma, só a incitação à finitude pode quebrar a letargia do tédio póshistórico, possibilitando novas lufadas historicizantes. No caso específico do curso de 1929, o tédio profundo conduz a um tal despossuimento de si e a uma experiência tão radical de autonadificação, que desta "revelação do nada fútil no tempo vazio, o Dasein ascende a uma exacerbação aguda da existência no tempo da ação" (id., 2009a, p. 553). Como em muitos outros textos de Heidegger, neste também acontece de o inimigo da dialética insistir numa dialetização, segundo a qual o negativo termina por liberar sua enorme força positiva, fazendo do derrotado um vitorioso especial.

O que Heidegger buscava era um antídoto contra uma existência tornada leve e na qual nada é muito significativo, daí a tentativa de retomar a gravidade do "caso crítico" (id., ibid., p. 551) e das situações-limite. Para vencer a dispersão e a falta de recolhimento, é preciso contar com a experiência da comoção e o poder do negativo. $\mathrm{O}$ mestre de Freiburg pretendia com isso

redramatizar o mundo pós-histórico [...]. Como dramaturgo do ser que terá de voltar a advir, Heidegger exprime o postulado de uma evasão para fora da platitude pós-histórica a partir do centro de reflexão Alemanha, como que para admitir a história mais uma vez, no último momento (id., 2008b, p. 188).

Para Sloterdijk, a fobia conservadora à leveza resume, em certo sentido, a participação de Heidegger no movimento da revolução nacional-socialista: o velho heroísmo da gravidade, comum também a pensadores como Gehlen e Schmitt, recusava "as condições modernas da vida na "sociedade de consumo" (id., 2009a, p. 553). Contrariamente ao que Heidegger esperava do apelo capaz de ultrapassar o confortável, 
o desenraizado e o arbitrário, Sloterdijk afirma que a única coisa com a qual se podia contar - moralmente falando - era o antifascismo, e este era aliado dos Estados Unidos, “esses perfeitos exemplos de migração para fora da 'história' que, em suplemento ao interior total do palácio de cristal, haviam de inventar o parque nacional e o parque de atrações pós-históricas em pleno ar livre” (id., 2008b, p. 188).

Parece claro que, para Sloterdijk, não há uma decisão, seja ela ativa do Dasein ou sofrida medialmente por este, que seja capaz de abrir "outro início da história" (HEIDEGGER, 2015, p. 93). O homem moderno é aquele que prefere a satisfação com o ente e os mimos do bem-estar à ousadia do seer $\left(\right.$ Seyn) $:^{90}$ ele não pretende convalescer-se da dispersão no ente, restituindo a solidez do seer. Distante do páthos heroico, a vida civilizada, imunizada tecnicamente, libera o homem do esforço excessivo da situação-limite, descarregando-o do peso e da gravidade. Leveza e levitação são os termos-chave para uma analítica da modernidade assumida. "Quem não quer falar do impulso para cima tem de guardar silêncio [...] sobre a modernidade" (SLOTERDIJK, 2009a, p. 543).

O que está em jogo aqui é toda uma redefinição do conceito de realidade sem os traços duros do peso, da luta e da necessidade. Porque na civilização avançada da superabundância, os indivíduos estão mais descarregados, apenas os atletas e os que se autointitulam casos críticos estão obrigados, por autoimposição arbitrária, a uma relação conflituosa e pesada com o real. Contra o mestre de Freiburg, que acolheu o chamado da gravidade, Sloterdijk aposta na leveza e no impulso antigravitacional. Os seres humanos são seres criadores de mundo e a esferologia pluralista das espumas reconhece a multiplicidade das células-mundo. As espumas são espaços de animação surreais e fantasiosos, mas habitáveis, e no seu interior, os seres humanos encontram efetivamente lugar. Há assim uma pluralidade de realidades.

Under your Private Sky seria a resposta esferológica à pergunta: onde você realmente está? A palavra "privado" não significa aqui o fechamento do indivíduo em uma ilusão concebida para ele; mostra

\footnotetext{
90 Esta é a grafia utilizada por Heidegger no livro Contribuições à filosofia: do acontecimento apropriador para o termo "ser", que na tradução brasileira se optou por "seer". Nesta obra, no item 44 intitulado "Sobre as "decisões", o filósofo elenca doze pares pendulares do tipo se isto ou aquilo... Cito aqui três delas: 1) "Sobre se o ente enquanto o que há de mais óbvio solidifica tudo o que é médio, pequeno e mediano em meio à sua transformação em algo racional ou se o que há de mais questionável constitui a solidez integral do seer"; 2) "Sobre se o homem ousa o seer e, com isso, o ocaso ou se ele se satisfaz com o ente"; 3 ) "Sobre se a natureza é rebaixada a uma região de espoliação pelo cálculo e pelo erigir e se transforma, assim, em ocasião de 'vivência' ou se ela suporta como a terra que se cerra o aberto do mundo sem imagem" (HEIDEGGER, 2015, p. 92).
} 
que o habitar real tem lugar sob tendas, que, naturalmente, só cobrem um pequeno segmento do todo. $\mathrm{O}$ formato é a mensagem, o pedaço do real é o real. (id., ibid., p. 561)

Há, portanto, inúmeros reais, milhares de tipos de espumas constituídas micromaníaca, microdelirante ou micro-histericamente.

Parece claro que Sloterdijk é um pensador epocal que diagnostica e mostra o que é viver no grande interior do palácio de cristal sem demonizar e sem condenar a habitação na tecnosfera. Como já foi dito, não há, para ele, um ultrapassamento das condições modernas, nem qualquer processo revolucionário que levasse as massas para fora do habitáculo técnico. A questão é apenas de maior integração das populações ao mundo confortável possibilitado pela tecnociência. É também dentro do contexto da discussão, em torno da diagnose da forma arquitetônica, que melhor desvende o mundo capitalista, que aparecem as deficiências da escolha benjaminiana pelas passagens parisienses. Para Sloterdijk, essa escolha é equivocada e ultrapassada, principalmente se comparada com a forma fechada do edifício escolhido por Dostoiévski. Se a forma fechada já comportava "uma alusão ao capitalismo integral, orientado para o vivencial, popular, no qual o que estava em jogo mais não era do que a absorção global do mundo exterior em um espaço integralmente calculado" (id., 2008b, p. 190), as passagens não tinham essa forma de um todo fechado, mas eram abertas para praças e ruas. Enquanto pelas passagens podemos sair após atravessar as "ruas lascivas do comércio" e os "templos do capital das mercadorias", nas palavras de Walter Benjamin, citado por Sloterdijk (ibid.), o palácio já diz de um lugar que talvez não possamos ou não precisemos deixá-lo.

Sloterdijk acredita que Benjamin focou sua atenção em um edifício ultrapassado e que a interpretação das passagens baseada unicamente na ideia de que o fetichismo da mercadoria esconde o subsolo dantesco do trabalho impediu-o de "por a nu a energia do modus vivendi capitalista, criadora de interior e de contexto" (id., ibid., p. 189). Um edifício anacrônico como as passagens não poderia desvendar a dinâmica do capital tanto quanto o palácio de cristal, no qual a própria sociedade vira objeto de exposição. O tamanho pequeno e elitista das passagens contrasta com a enormidade abarcadora palaciana, prefiguradora já, em pleno século XIX, do projeto capitalista, que consiste em "transpor a totalidade da vida do trabalho, dos desejos e da expressão artística dos seres para a imanência do poder de compra" (id., ibid., p. 191). 
Benjamin menciona o palácio nos seus estudos, mas não desvenda o sentido profético presente naquela forma arquitetônica. Seus trabalhos - guiados fundamentalmente pelo desejo de ver em "todas as formas de expressão do contexto financeiro moderno" o repertório da alienação (id., ibid., p. 189) - testemunham, para Sloterdijk, "a felicidade vingadora do melancólico, que constitui um arquivo para provar que o mundo é um fracasso" (id., ibid.).

É comum, em Sloterdijk, a apropriação das ideias dos pensadores precedentes para levá-las adiante e corrigi-las. Aquilo que ele faz com Heidegger (correção e desenvolvimento da analítica do espaço), com Nietzsche (alargamento e aplicação das categorias nietzscheanas ao universo político em Ira e tempo; crítica da noção de alémhomem em Tu deves transformar tua vida; validação e correções da antropologia especulativa da Genealogia da moral com estudos empírico-positivos, entre outras operações), com Spengler (correção e desenvolvimento do termo "morfológico"), com Gehlen (inversão do sinal da antropologia da carência), repete-se aqui com Walter Benjamin, ${ }^{91}$ de um modo ainda mais incisivo. Trata-se de discriminar o que ainda é vivo e válido em um pensador daquilo que é preciso corrigir ou abandonar por ter caducado. E o critério, aqui, como sempre, é a própria exposição experiencial do filósofo ao seu tempo: "se alguém quiser dizer algo enquanto intelectual contemporâneo, tem de sentir os excedentes ilusórios da sua própria época e o seu terror" (id., 2007, p. 14). O intelectual não é um mensageiro do absoluto nem um agraciado pelo ser, mas alguém que tem "ouvido para as detonações do nosso tempo" (id., ibid.) e diz o que diz porque atravessa e está em consonância com o relógio epocal. No caso de Benjamin, Sloterdijk afirma que quem quiser herdar o legado deste gênio, que trabalhava sempre para o lado do beco sem saída, precisa submetê-lo tanto a "correções metodológicas" (id., 2008b, p. 189) quanto a reorientações de fundo.

Assim, a referência para se entender o presente deve ser buscada nas maquetes dos shoppings centers, "nos centros de feiras, nos grandes hotéis, nas arenas desportivas

\footnotetext{
${ }^{91}$ Provavelmente, a crítica mais importante que o pensamento de Sloterdijk dirige a Benjamin, e que é extensiva a Adorno, reside no páthos extremista e depressivo do seu núcleo filosófico, o que é compreensível se se atenta para o esforço sloterdijkiano de inverter esse páthos na filosofia do presente e possibilitar uma relação mais serena com a modernidade, lida em termos de progressiva descarga do peso do mundo e incremento dos mimos por meio de próteses oferecidas no processo de explicação. Assim, o processo civilizacional, ao assegurar substituições, favorece a replicação de cuidados. Um exemplo é a maternidade, que, uma vez explicitada, permite a um outro desempenhá-la. No caso de Benjamin, sua imagem do anjo da história, que via diante de si o acúmulo incessante das ruínas, representa para Sloterdijk o paradigma de um "século ofuscado por radicalismos" (SLOTERDIJK, 2009a, p. 528), que cabe a nós ultrapassar. Não obstante este conjunto de críticas, o diálogo de Sloterdijk com Benjamin é profícuo como veremos a seguir na discussão em torno do conceito de experiência.
} 
e nos parques de aventuras indoors" (id., ibid., p. 190). E quanto à famosa tese benjaminiana, exposta no texto de juventude, Kapitalismus als Religion (1921), de que o capitalismo universalizaria as dívidas e a culpa, Sloterdijk mostra que se dá exatamente o contrário, pois o capitalismo troca o "escudo psicossemântico proposto pelas religiões históricas pelos sistemas de previdência ativista” (id., 2008b, p. 191). Além disso, para Sloterdijk, também o socialismo/comunismo era um projeto simétrico ao capitalista: ambos visavam igualmente o palácio de cristal e o consumismo. A diferença está apenas em que

na [...] interpretação capitalista, as correntes do desejo conhecem um desenvolvimento de potência incomparável - o que também começam a admitir pouco a pouco os que tinham comprado ações do socialismo na bolsa das ilusões, ações de que se conservarão alguns exemplares, como essas notas de mil milhões de marcos do ano de 1923 (id., ibid.).

Uma das características fundamentais da globalidade consumada e, portanto, da estadia no grande palácio de vidro, é a densificação e a "vizinhança forçada" (id., ibid., p. 192) com coexistentes casuais. Onde vigoram as relações densas, diminuem a liberdade de agir e a não comunicação. No meio denso, os agentes se inibem mutuamente e se tornam cooperadores triviais. As telecomunicações são a "concretização prática da densificação" (id., ibid., p. 193), e quem reflete sobre os bilhões de e-mails por segundo ou nas trocas de trilhões de dólares sabe que a "produção do contexto mundial" (id., ibid.) visa a cooperação e, portanto, a inibição. A condição de alta densidade torna obsoleta a ofensiva unilateral e filtra inovações perigosas. Se a integração progressiva do outro no interior palaciano implica no amortecimento da ação, quem reivindica a desinibição ativa e a liberdade de agir é o crime organizado e o terrorista: são eles que detêm o monopólio da práxis na situação pós-histórica. $\mathrm{O}$ ato terrorista de 11 de setembro de 2011 sinaliza que novos atores tomaram para si o "motivo da desinibição" (id., ibid., p. 195).

[Estes] perdedores do campo não ocidental [...], ao contrário do que até então tinham feito os movimentos de perdedores após 1789, não imitam o modelo de uma "revolução"; macaqueiam directamente o momento original das expansões europeias após 1492. (id., ibid.)

Se os antigos conquistadores, em pleno gozo da unilateralidade, colocavam suas bandeiras em territórios, os terroristas assentam agora as suas na infovia do palácio de 
cristal. Eles são os provedores de conteúdo no assunto violência e o espaço da informação difunde a agressão aos "consumidores do terror" (id., ibid., p. 196). No interior dessa megainstalação de luxo, na qual os entes disponibilizados tecnicamente são acessados pelo poder de compra da subjetividade consumidora, os entediados consomem o terror, e a ideia de que haveria um inimigo externo, quando, na verdade, a agressão terrorista depende inteiramente do caráter hipercomunicativo da infosfera. Houvesse um silenciamento dos media ou uma "quarentena da informação" (id., ibid.), o terrorismo deixaria de existir, pois ele vive apenas do "processo mediático secundário" (id., ibid., p. 200).

Se a era histórica estava ligada a uma ética da ação, o palácio pós-histórico define o âmbito de uma ética da responsabilidade. Esta transição significa a "expulsão dos atores para fora do paraíso" (id., ibid., p. 202). O unilateralismo da conquista dá lugar ao caráter temeroso diante de efeitos colaterais de ações e às retroações. Os recuos impostos pela responsabilidade e multilateralismo fazem definhar a exuberância do começo espontâneo, pois, agora, tudo começa de um imenso e complexo emaranhado já tecido. Também a arte e o seu raio de ação inicial e fulgurante dá lugar ao redizer do redito e à hibridização. Segundo a fórmula de Sloterdijk, "a originalidade é, como a monocausalidade, um conceito para as pessoas de antigamente" (id., ibid., p. 205). Enquanto no era da ação, a energia desinibidora avança desbastando zonas virgens, na situação pós-histórica densa cada ação é mil vezes sopesada e interditada, tendo em vista os desencadeamentos de efeitos secundários de vários tipos: para

pregar um prego, é preciso o acordo de uma comissão que, antes de abordar a questão do prego, elege o presidente, o vice-presidente, o secretário, o delegado para as questões femininas e um membro externo que expõe as considerações éticas relativas à avaliação das consequências técnicas e ecológicas (id., ibid., p. 206).

Se, na situação pós-histórica, os artistas continua a simular inovações e radicalismos, quem esclarece a era das retrações é o ambiente das terapias de grupo, nas quais, alguém só fala depois que algum outro disse isso ou aquilo... e isso após alguém já ter falado antes.

Sloterdijk acredita que Dostoiévski captou a Stimmung na "realidade indoors generalizada" (id., ibid., p. 208) e os acontecimentos, mesmo os mais extraordinários, acontecem sob o teto de vidro. Quanto às populações abrigadas sob este teto imunológico, pode se dizer que, pelo menos dois terços dos quase 7 bilhões da nossa 
espécie estão excluídos e tentam sobreviver “em meio às suas tradições e improvisações" (id., ibid., p. 209). Há, para o autor da Crítica da razão cínica, "uma impossibilidade sistêmica de organizar materialmente uma integração de todos os membros do gênero humano num sistema de prosperidade homogênea, nas condições atuais da técnica, da política energética e da economia" (id., ibid., p. 210). Como a maioria não tem poder de compra e acesso aos mimos e confortos, a "crítica" se universaliza na delação da miséria, mas não aponta "os meios de a ultrapassar" (id., ibid.).

Mesmo havendo bilhões de seres não incluídos na grande estufa, não há oposição exterior ao palácio - "os against men”, de Negri e Hardt, ${ }^{2}$ já não se diferenciam dos "demais contemporâneos" (id., 2009a, p. 622) - tampouco uma outra forma de vida capaz de rivalizar com a palaciana. Para o pensador de Karlsruhe, a grande zona de conforto artificial, contrariamente a Heidegger e Dostoiévski, não é ultrapassável, muito embora o seu desenho imunológico sirva "à fração da humanidade com poder de compra” (id., 2008b, p. 211). Quem vive sob o céu técnico, já não está entre o céu e a terra, mas numa grande máquina de acessos cuja senha é o dinheiro. $\mathrm{O}$ possuidor de dinheiro acessa e dispõe de uma enormidade de coisas e equipamentos que podem, a qualquer momento, mudar de mãos e ser revogáveis. O dinheiro introduz uma flexibilização que faz as coisas migrarem "do mundo da pertença, para o mundo das opções" (id., ibid., p. 222). Se no mundo da pertença vigorava o enraizamento, e a coisa ficava parada junto de um "único proprietário orgânico" (id., ibid., p. 223) - isto é, alguém que acessa algo sem custos, pelo mero fato de ser isto ou aquilo, de ter esta ou aquela identidade -, no mundo das opções muda o "o estatuto ontológico das coisas e das pessoas" (id., ibid., p. 224) e ambas se flexibilizam, incluindo a identidade humana.

Sloterdijk é o pensador da segunda metade do século XX que, na esteira de Benjamin, Musil, Heidegger e outros, melhor articulou a transformação técnicomonetária do mundo. O ultrapassamento do natural pelo artificial e a consequente era das opções exprimem-se "cognitivamente pelo construtivismo" (id., ibid., p. 224). Como foi visto em Esferas III, uma vez que os entes encontram-se explicitados, posso construí-los e reconstruí-los, e são essas novas possibilidades que (in)determinam e passam a dominar, e não mais a transmissão tradicional. ${ }^{93}$ Nessas circunstâncias de

\footnotetext{
${ }_{92}^{92}$ Sloterdijk refere-se ao livro Império, de Antonio Negri e Michael Hardt.

93 Este seria o momento para introduzir um outro adendo focado nos trabalhos de Robert Musil e de Walter Benjamin, pois, tanto a questão do homen sem qualidades quanto a temática do empobrecimento
} 
hegemonia explicativa, qualquer coisa pode ser colocada às claras e ver revelada a "sua 'construção', a sua 'invenção', as suas 'politics"' (id., ibid., p. 224). Este desenraizamento e esta "demolição do natural se vai infiltrar nas relações do ser humano consigo próprio - razão pela qual, em clima construtivista, não se fazem bons prognósticos para as identidades fixas" (id., ibid.). É certo que esta flexibilização e desenraizamento têm limites e não pode desbaratar o enraizamento matricial exposto em Esferas I, nem que "possamos deixar de dizer de onde viemos e como nos situamos num quadro mais vasto" (id., ibid.).

A flexibilização não é uma psicotização. O que ocorre na era desonerada é que o "ego utente" toma o lugar do "ego culto" (id., ibid., p. 233). Se o último era o homem educado da Bildung, que guardava e recolhia o nexo coeso da sua história vivida, o utilizador de novos meios não literários já não precisa mais "recolher experiências" (id., ibid., p. 234). Ele as chama e as recolhe, mas, agora, o

que recolhe não são experiências, isto é, complexos de saber integrados sob forma pessoal, narrativa e conceitualmente ordenados: são endereços onde poderá dispor de agregados de saber mais ou menos formatados se, por uma razão ou por outra, quiser recorrer a eles (id., ibid.).

O “empobrecimento da experiência”, para usar a expressão benjaminiana, decorre da acessibilidade instantânea concedida pelos novos meios. Para que recolher camadas e camadas de pesquisas e integrá-las ao meu contexto de vida, se posso, num toque, dispor de qualquer informação? Essa é a pergunta que o homem leve e liberado dirige ao cultivado. Este, parece, é um perdedor ultrapassado, pois mesmo nas universidades e nos centros de humanidades, a cognição já há muitas décadas afastou-se da experiência...

Parafraseando o anti-heroi das Notas do subterrâneo, livro de Dostoiévski no qual aparece a questão do palácio de cristal, encerro este último capítulo da tese de forma um tanto arbitrária, pois ainda haveria muito a dizer sobre a vida no grande interior da estufa artificial... "Mas parece-me que se pode parar por aqui..." (DOSTOIÉVSKI, 1986, p. 137).

da experiência radica, em última análise, na viragem técnica. É somente à luz da explicação sloterdijkiana da era construtivista que se pode apreender a experiência de fundo que essas duas obras tentavam digerir. Sobre este tema cf. o ensaio "Musil e Benjamin: a ética do homem sem qualidades e o empobrecimento da experiência", a ser publicado nos Cadernos Benjaminianos (UFMG), que escrevi com Luciana Araujo Marques. 


\section{Conclusão}

A esferologia sloterdijkiana oferece um "princípio continuum" (SLOTERDIJK, 2009a, p. 620) capaz de consolidar uma analítica do lugar que cobre desde os agrupamentos arcaicos até as formas de vida contemporâneas. Esse continuum é a ideia condutora de receptáculo e é ela que permite percorrer e identificar as várias formas de inclusão (de ser-em). Dos receptáculos metabiológicos que abrigaram os primeiros hominídeos à estadia atual na superinstalação artificial, Sloterdijk mostra, com riqueza de detalhes histórico-filosóficos, as sucessivas metamorfoses na forma do mundo. $\mathrm{O}$ repertório da esferologia abre o campo semântico da filosofia, liberando-a do ponto de partida do indivíduo e do sujeito para pensar os fenômenos da animação e da conformação de mundos. Se a introdução do tema da animação e do aliado constitui por si só uma revolução paradigmática, ${ }^{94}$ que rompe com o pensamento moderno do "eu", as consequências dessa reviravolta são muito férteis. Isso porque as conformações de mundo são simultaneamente regimes específicos de relação com o aliado: no formato bolha, o regime da complementação é do tipo da díade mãe-bebê; o formato globo implica uma aliança complementadora na qual o ser humano é um sócio minoritário do absoluto e, quando o onde é a espuma, a autocomplementação individualista se dá por meio de aparelhos, máquinas protetizadoras e sistemas de caridade e de solidariedade. Se o primeiro formato se comprova, como se procurou mostrar, nos achados clínicos winnicottianos e pós-winnittianos da clínica não interpretativa do cuidado, o segundo formato abre para a filosofia a discussão da grande era do Homo Metaphysicus sob a chave imunológica. A forma globo possibilita assim o recontar da história de Deus e de suas relações com os homens. A ideia sloterdijkiana de que o homem metafísico é aquele abrigado no interior de um design imunológico específico, no qual a palavra "absoluto" goza de plenos direitos, e a Alma do mundo envolve a todos numa inclusividade benévola, é uma ideia que abre um enorme campo de discussão para teólogos e historiadores da filosofia que aceitem o desafio de olhar as coisas pelo viés da imunidade, sem dúvida, a contribuição central da esferologia. Quanto à analítica da espuma, é ela, certamente, que despertará mais polêmicas, pois a maioria dos

\footnotetext{
${ }^{94}$ Este termo tornado famoso por Thomas Kuhn foi utilizado por Ernildo Stein em Seis estudos sobre "Ser e tempo" para caracterizar o pensamento de Heidegger, e como se viu no capítulo 2 deste trabalho, também é utilizado por Z. Loparic no campo da psicanálise para se referir à vertente winnicottiana. Esta tese tentou sugerir que o que Heidegger representou para o século $X X$, na condição de figura incontornável da filosofia, Sloterdijk já representa para o século que se inicia.
} 
intelectuais, na esteira de autores da grandeza de Heidegger, Gehlen e dos integrantes da Teoria Crítica, tendem a uma visão muito negativa da modernidade e, Sloterdijk, com sua leitura do mundo moderno, como marcha da explicitação contínua, acentua positivamente as virtudes desse processo, na medida em que ele é causador de mimo. A explicação facilita o impulso para o mimo, para a leveza e a liberação da necessidade. É algo inédito que uma obra filosófica de grande envergadura esteja "a serviço" do amigamento da realidade contemporânea.

Viu-se nesta tese que, no seu percurso, ${ }^{95}$ Sloterdijk progressivamente abandonou as subculturas românticas e rebeldes, bem como as investigações em torno da gnose, dos fundamentos da crítica radical e do estranhamento do mundo, para dignificar a experiência do mundo e o aspecto luxuoso da cultura. Esta operação de sim para o nosso mundo soará inquietante para muitos. Os elogios da leveza e do mimo poderão, num primeiro momento, causar estranheza ao leitor de Sloterdijk. Talvez, para atenuar este estranhamento, uma das estratégias de Esferas III seja a de mostrar que, para além da mera facilitação da vida e de holding, posteriores à morte de Deus, as imunidades técnicas e as suas "coisas" e "aparatos" também são vivos e animados. Sloterdijk recorre a Winnicott e a Latour para conferir direito e "subjetividade" às coisas. Há assim, um mundo comum de homens e coisas e elas "nos falam”. Não só nós a transformamos como a "república das coisas", no dizer de Latour, também nos transforma na mesma medida em que fraldas e ursinhos impulsionam e possibilitam o devir dos bebês. Além disso, no universo da explicitação crescente, há sempre o direito ao "não saber" e à destematização, conforme foi abordado na alergologia de Nietzsche. ${ }^{96}$

Se o sim para a realidade contemporânea, e sua leveza desoneradora no "espaço pós-necessitário" (id., 2008b, p. 227), causa uma certa perplexidade é, provavelmente,

\footnotetext{
${ }^{95}$ Na língua do clichê e do estereótipo literário, se poderia contar o caminho de Sloterdijk desde o estudante que se nutria de Bloch, Adorno e Sartre, passando pelo jovem cabeludo que frequentava grupos terapêuticos na Índia sob a supervisão de Osho, desgostoso já com o "clima" e a colonização do jargão filosófico pela Teoria Crítica, até o engravatado reitor da Escola Superior de Artes Aplicadas de Karlsruhe, com um programa, famoso na Alemanha, de debates televisivos. A riqueza de experiências e de lugares de olhar, nesse percurso, faz de Sloterdijk, nietzscheanamente falando, um filósofo no sentido mais forte da palavra, com uma liberdade que transcende escolas, modas e posições fixas. Ele tem "mão bastante para deslocar perspectivas" (NIETZSCHE, 2007, p. 25). Frequentemente, quando Sloterdijk dialoga com algum outro autor, nota-se que ele conhece a posição melhor do que o próprio, por já ter percorrido e passado por aquele lugar de experiência e de pensamento.

${ }^{96}$ Deve-se notar também que, com a desoneração da vida, Sloterdijk não recomenda o consumo e a mera busca hedonista pelo conforto. Ao contrário, a liberação do fardo da necessidade possibilita a busca dos exercícios melhores para cada um (Du Mußt dein Leben ändern) e o investimento de forças timóticas (não eróticas) nisso. Melhor exemplo é o próprio Peter Sloterdijk que, em vez de passear e olhar vitrines, escreveu uma obra ambiciosa de mais de trinta volumes.
} 
não só porque muitos espíritos se entristecem com o fato de que o capricho e a banalidade ganham tanto espaço, mas também porque é mais difícil dizer sim do que não. (O sim implica um engajamento construtivo muito trabalhoso.) Uma das virtudes da esferologia sloterdijkiana, e sua já mencionada virada de Stimmung, é atenuar o déficit de sim na filosofia contemporânea e desconfiar do comodismo da negação e da indústria da indignação.

Sloterdijk não dá continuidade às teses pós-heideggerianas do primado do não e o seu endeusamento pelas subculturas estéticas. Ao contrário, ele mostra que o desamparo e o não dependem de fracassos na participação. Não há assim, um superinvestimento na categoria do desamparo: são muito poucos os que nele obram ou dizem e fazem a partir do não-lugar ou de sua transfiguração mística. Segundo a esferologia, enformada winnicottianamente, a primeira tese de uma topologia geral poderia ser dita na fórmula: ao sermos humanos somos num lugar! Desse modo, como o adendo I procurou esclarecer, o elogio de Kafka por Blanchot ou Bataille, similar ao de Deleuze a Artaud ou a de Lacan a Joyce e Duras - que consagram o artista radical como uma espécie de paradigma para ultrapassar o pobre cidadão comum identitário, que apenas reproduziria o ranger estridente do mesmo e da máquina do mundo alienada são elogios um tanto suspeitos, principalmente quando pretendem migrar do campo do extremismo da subcultura estética para o do gesto político. Não há dúvida de que, em maior ou menor grau, todos esses elogios que aguardam um "homem novo" repetem a admiração de Heidegger por Hölderlin ${ }^{97}$ e a sua espera pelo mortal não mais metafísico. Contra esta última religião da modernidade, Sloterdijk mostra que a outra época diferente, no sentido do mago de Meßkirch, de homens "eckartianos" que prescindiriam da identidade, jamais chegará. Uma vez que esse homem novo, resultado de uma transformação na essência do ser humano e de sua relação com a negatividade, não virá, é mais conveniente situar a discussão política a partir das imunidades dos sistemas de amparo. Assim, a própria discussão política hoje em voga, no Brasil e no mundo, sobre a crescente diminuição de direitos e a desarticulação do Wellfare State é, fundamentalmente, uma discussão imunológica, que versa sobre o quanto há de perda no repertório moderno dos amparos, dos mimos e das desonerações.

Dito de um modo sintético pode-se afirmar que se Esferas I põe em nova chave a questão da antropogênese, e Esferas II, o modo de contar a história de Deus, Esferas III

\footnotetext{
${ }^{97}$ Lacan em Lituraterra chega a dizer que Joyce "foi direto ao melhor que se pode esperar de uma análise no fim".
} 
reabre o debate em torno do presente com mais sensatez, pois nos liberta da hermenêutica dos extremos e do ponto de vista dos eleitos. Esta é uma contribuição terapeuticamente importante, pois, apesar da pluralidade dos mundos, estamos no mesmo barco.

Para concluir este trabalho, gostaria de evocar na mente do leitor alguns dos conceitos mencionados com os quais Sloterdijk ampliou o vocabulário filosófico e libertou a filosofia tanto do jargão do pensamento moderno da subjetividade quanto da já esgotada virada para a linguagem (com todas as subvariantes da ideia de que o universo é um caso do discurso). Nos termos elencados a seguir, parece-me que não só a filosofia se expandiu generosamente como se abriu para um amplo espectro de leitores desejosos de nela ainda encontrar respostas sérias à pergunta pelo onde e pela localização. São alguns deles: díade, consubjetividade, animação, ek-stase, ens-tase, ontologia da carência, stress, antroposfera, peso e leveza, inibição e desinibição, póshistória, antropologia da riqueza, mimo, isolamento conectado, ilhas artificiais, nãoobjetos etc. Nestes termos, oriundos do diálogo com várias áreas, abrem-se questões incontornáveis para aquele que pretende seguir pensando, apesar das dificuldades, e não quer se entregar aos automatismos e mantras do já conhecido. O incontornável, bem entendido, significa algo muito além da mera concordância ou discordância com o autor. 


\section{Referências bibliográficas}

\section{Livros de Sloterdijk}

SLOTERDIJK, P. A árvore mágica. Trad. Andrea J. H. Fairman. Rio de Janeiro: CasaMaria Editorial,1988.

Mobilização copernicana e desarmamento ptolomaico. Trad. Heidrun Krieger

Olinto. Rio de Janeiro: Tempo Brasileiro, 1992.

No mesmo barco: ensaio sobre a hiperpolítica. Trad. Claudia Cavalcanti. São

Paulo: Estação Liberdade, 1999a.

. Sphären II. Frankurt: Suhrkamp, 1999 b.

1. Essai d'intoxication volontaire. Trad. Olivier Mannoni. Paris: Calmann-Lévy, 1999c.

El pensador en escena: el materialismo de Nietzsche. Trad. de Germán Cano. Valência: Pre-Textos, 2000a.

$2000 \mathrm{~b}$.

La Domestication de l'être. Trad. Olivier Mannoni Paris: Mille et une Nuits,

Regras para o parque humano. Trad. José Oscar de Almeida Marques. São

Paulo: Estação Liberdade, 2000c.

A mobilização infinita: para uma crítica da cinética política. Trad. Paulo Osório

de Castro. Lisboa: Relógio D’Água, 2002a.

. O desprezo das massas: ensaio sobre lutas culturais na sociedade moderna.

Trad. Claudia Cavalcanti. São Paulo: Estação Liberdade, 2002b.

Esferas I. Trad. Isidoro Reguera. Madri: Siruela, 2003.

. Esferas II. Trad. Isidoro Reguera. Madri: Siruela, 2004a.

. O quinto "evangelho" de Nietzsche. Trad. Flávio Breno Siebenichler. Rio de

Janeiro: Tempo Brasileiro, 2004b.

Venir al mundo, venir al linguaje: lecciones de Frankfurt. Trad. German Cano.

Valência: Pre-Textos, 2006

O sol e a morte. Trad. Carlos Correia Monteiro de Oliveira. Lisboa: Relógio D’Água, 2007.

2008a.

O estranhamento do mundo. Trad. Ana Nolasco. Lisboa: Relógio D’água,

Palácio de cristal: para uma teoria filosófica da globalização. Trad. Manuel Resende. Lisboa: Relógio D’Água, 2008 b.

. Esferas III. Trad. Isidoro Reguera. Madri: Siruela, 2009a.

$2009 \mathrm{~b}$.

Derrida, um egípcio. Trad. Evando Nascimento. São Paulo: Estação Liberdade,

. "Cioran ou l'excès de la parole sincère". In: TACOU, Laurence \& PIEDNOIR, Vincent. L'Herne. Trad. Olivier Mannoni. Paris: L'Herne, 2009b.

Die nehmende Hand und die gebende Seite. Berlim: Suhrkamp, 2010.

Sin salvación: tras las huellas de Heidegger. Trad. Joaquín Chamorro Mielke.

Madri: Akal, 2011.

Crítica da razão cínica. Trad. de Marco Antonio Casanova et al. São Paulo:

Estação Liberdade, 2012a.

- Ira e tempo: ensaio político-psicológico. Trad. de Marco Antonio Casanova.

Estação Liberdade, 2012b.

. Temperamentos filosóficos: um breviário de Platão a Foucault. Trad. João

Tiago Proença. Lisboa: Edições 70, 2012c. 
. Has de cambiar tu vida. Trad. Pedro Madrigal. Valencia: Pre-Textos, 2013.

2014.

Morte aparente no pensamento. Trad. Carlos Leite. Lisboa: Relógio d'Água,

Après Nous Le Déluge. Trad. Olivier Mannoni. Paris: Payot, 2016.

\section{Sobre Sloterdijk}

BOLZ, Norbert. "Sein und Raum". In: Jongen, Marc et al (org.). Die Vermessung des Ungeheuren. Munique: Wilhelm Fink, 2009.

CORDUA, Carla. Sloterdijk y Heidegger: la recepción filosófica. Santiago do Chile: Universidad Diego Portales, 2008.

COUTURE, Jean-Pierre. "A Public Intellectual”. In: ELDEN, Stuart (org.). Sloterdujk Now. Cambridge: Polity, 2012.

ELDEN, Stuart (org.). Sloterdujk Now. Cambridge: Polity, 2012.

GUMBRECHT, Hans Ulrich. "In der Welt sein und auf der Bühne stehen: Die intellektuelle Physiognomie von Peter Sloterdijk". In: JONGEN, Marc et al (org.), Die Vermessung des Ungeheuren. Munique: Wilhelm Fink, 2009.

JONGEN, Marc et al (org.). Die Vermessung des Ungeheuren. Munique: Wilhelm Fink, 2009.

KATE, Laurens ten. "Zwischen Immunität und Unendlichkeit: Der Ort in Peter Sloterdijks Sphärologie im Hinblick auf seine philosophische Analyse des christlichen Erbes". In: JONGEN, Marc et al (org.), Die Vermessung des Ungeheuren. Munique: Wilhelm Fink, 2009.

KRISTAL, Efraín. "Literature in Sloterdijk's Philosophy”. In: ELDEN, Stuart (org.), Sloterdijk Now. Cambridge: Polity, 2012.

LATOUR, Bruno. "Spheres and Networks: Two Ways to Reinterpret Globalization" (palestra na graduação em design de Harvard). In: Harvard Design Magazine, 30 primavera/verão, 2009.

MARQUES, José Oscar de A. "Sobre as Regras para o parque humano de Sloterdik". Natureza Humana, v. IV, n. 2, 2002, p. 363-381.

WERNTGEN, Cai. "Denken am Nullpunkt der Geschichte: Notizen zur Philosophie Peter Sloterdijks". In: Die Vermessung des Ungeheuren. Munique: Wilhelm Fink, 2009.

\section{Entrevistas com Sloterdijk}

Spheres Theory: Talking to Myself About the Poetics of Space. Harvard Universtiy Graduate School of Space. 17 fev. 2009 (Palestra de Sloterdijk em forma de entrevista consigo mesmo). Publicado na Harvard Design Magazine, primavera/verão 2009, n. 30. Entrevista com Sloterdijk no Simpósio do Berggruen Center em Filosofia e Cultura realizada no St. John's College of Divinity, Cambridge University, 25, jun. 2015.

\section{Livros de Heidegger}

HEIDEGGER, Martin. Heidegger. "Que é metafísica?", "Carta sobre o humanismo", "Tempo e ser” (Coleção Os Pensadores). Trad. Ernildo Stein. São Paulo: Abril Cultural, 1979.

L'auto-affirmation de l'université allemande. Trad. Gérard Granel. TransEurop-Repress, 1982.

Sein und Zeit. Tübingen: Max Niemeyer, 1984.

Der Feldweg. (edição sem informações de responsável, data e local) 
History of the Concept of Time: Prolegomena. Trad. Theodore Kisiel. Indianapolis: Indiana University Press/ Midland Book, 1992.

Serenidade. Trad. Maria Madalena Andrade e Olga Santos. Lisboa: Instituto Piaget, 2000.

. A caminho da linguagem. Trad. Marcia Sá Cavalcante Schuback. Petrópolis:

Vozes, 2003a.

Os conceitos fundamentais da metafísica: mundo, finitude, solidão. Trad. Marco

Antonio Casanova. Rio de Janeiro: Forense Universitária, 2003b.

Vozes, 2006.

Ser e tempo ( $8^{\underline{a}}$ ed). Trad. de Márcia Sá Cavalcante Schuback. Petrópolis:

. Was ist metaphysik? (60 $\mathrm{a}$ ed.). Frankfurt: Vittorio Klostermann, 2007.

Introdução à filosofia. Trad. de Marco Antonio Casanova. São Paulo: Martins

Fontes, 2008.

. Fenomenologia da vida religiosa. Trad. Enio Paulo Giachini; Jairo Ferrandin e

Renato Kirchner. Petropólis: Vozes, 2010.

Contribuições à filosofia: do acontecimento apropriador. Trad. de Marco

Antonio Casanova. Rio de Janeiro: 2015.

\section{Livros sobre Heidegger}

CASANOVA, Marco Antonio. Compreender Heidegger, 2 $2^{\underline{a}}$ ed. Petrópolis: Vozes, 2009.

DUARTE, André. Vidas em risco: crítica do presente em Heidegger, Arendt e Foucault. Rio de Janeiro: Forense Universitária, 2010.

FRANCK, Didier. Heidegger e o problema do espaço. Trad. João Paz. Lisboa: Instituto Piaget, 1997.

HAAR, Michel. Heidegger e a essência do homem. Trad. Ana Cristina Alves. Lisboa: Instituto Piaget, 1997.

MACDOWELL, João Augusto A. Amazonas. A gênese da ontologia fundamental de Martim Heidegger. São Paulo: Herder/USP, 1970.

NUNES, Benedito. Passagem para o poético: filosofia e poesia em Heidegger. São Paulo: Loyola, 2012.

SHARR, Adam. La cabaña de Heidegger: um espacio para pensar. Trad. Joaquín Rodríguez Feo. Barcelona: Gustavo Gili, 2008.

STEIN, Ernildo. Seis estudos sobre "Ser e tempo" (Martin Heidegger). Petrópolis: Vozes, 1988.

XOLOCOTZI, Ángel; TAMAYO, Luis. Los demonios de Heidegger: Eros y mania en el maestro de la Selva Negra. Madri: Trotta, S. A., 2012.

ZARADER, Marlène. A dívida impensada: Heidegger e a herança hebraica. Trad. Sílvia Meneses. Lisboa: Instituto Piaget, 1999.

ZIMMERMAN, Michael E. Confronto de Heidegger com a modernidade: tecnologia política arte. Trad. João Sousa Ramos. Lisboa: Instituto Piaget, 2001.

\section{Geral}

ADORNO, Theodor W. Minima Moralia: reflexões a partir da vida lesada. Trad. Gabriel Cohn. Rio de Janeiro: Azougue, 2008.

\& Horkheimer, Max. Dialética do esclarecimento: fragmentos filosóficos. Trad.

Guido Antonio de Almeida. Rio de Janeiro: Jorge Zahar, 1985.

AGAMBEN, Giorgio. O que é contemporâneo? e outros ensaios. Trad. Vinícius Nicastro Honesko. Chapecó: Argos, 2009. 
Homo sacer: o poder soberano e a vida nua I. Trad. Henrique Burigo. Belo Horizonte: UFMG, 2010.

. A potência do pensamento: ensaios e conferências. Trad. António Guerreiro. Belo Horizonte: Autêntica, 2015.

AGOSTINHO, Santo. A Cidade de Deus (Parte I). Trad. Oscar Paes Leme. Petrópolis: Vozes, 1989.

ALMEIDA, Jorge \& BADER, Wolfgang. Pensamento alemão. Trad. São Paulo: Cosac Naify, 2009.

ARENDT, Hannah. Homens em tempos sombrios. Trad. Denise Bottmann. São Paulo: Companhia das Letras, 1987.

A condição humana, $11^{\underline{a}}$ ed. Trad. Roberto Raposo. Rio de Janeiro: Forense Universitária, 2010.

Entre o passado e o futuro. $7^{\mathrm{a}} \mathrm{ed}$. Trad. Mauro W. Barbosa e outros. São Paulo, Perspectiva, 2014.

BACHELARD, Gaston. A psicanálise do fogo. Trad. Paulo Neves, Lisboa: Estudios Cor, 1972.

. A poética do espaço. Trad. de Antônio de Pádua Danesi. São Paulo: Martins Fontes, 2012.

BADIOU, Alain. A aventura da filosofia francesa do século XX. Trad. Antônio Teixeira e Gilson Iannini. Belo Horizonte: Autêntica, 2015.

BATAILlE, Georges. A experiência interior. Trad. Celso Libânio Coutinho, Magali Montagné e Antonio Ceschin. São Paulo: Ática, 1992.

A literatura e o mal. Trad. Fernando Scheibe. Belo Horizonte: Autêntica, 2015.

BLANCHOT, Maurice. L'espace littéraire. Paris: Gallimard, 1988.

. O livro por vir. Trad. Leyla Perrone-Moisés. São Paulo: Martins Fontes, 2005.

BENJAMIN, Walter. Magia e técnica, arte e política: ensaios sobre literatura e história da cultura (Obras Escolhidas I). Trad. Sérgio Paulo Rouanet. São Paulo: Brasiliense, 2012.

BOBBIO, Norberto. Dalla strutura ala funzione: nuovi studi di teoria del diritto. Milão: Edizioni di Comunità, 1977.

CACCIARI, M. Méridiens de la décision dans la pensée contemporaine. Combas: L'Éclat, 1992.

CASTELLO BRANCO, Lúcia. Os absolutamente sós: Llansol - a letra - Lacan. Belo Horizonte: Autência, 2000.

Chão de letras: As literaturas e a experiência da escrita. Belo Horizonte:

UFMG, 2011.

CIORAN, Emil. De I'Inconvénient d'être né. Paris: Gallimard, 1973.

DELEUZE, Gilles. Conversações. Trad. Peter Pál Pelbart. São Paulo: Editora 34, 1992. Crítica e clínica. Trad. Peter Pál Pelbart. São Paulo: Editora 34, 1997.

1998.

\& PARNET, Claire. Diálogos. Trad. Eloisa Araújo Ribeiro. São Paulo: Escuta,

DIAS, Elsa Oliveira. A teoria do amadurecimento de D.W. Winnicott. Rio de Janeiro: Imago, 2003.

DIDI-HUBERMAN, Georges. Sobrevivência dos vaga-lumes. Trad. Vera Casa Nova e Márcia Arbex. Belo Horizonte: UFMG, 2011.

DOSTOIÉVKSKI, Fiodor. Notas do subterrâneo. Trad. Moacir Werneck de Castro. Rio de Janeiro: Civilização Brasileira, 1986.

ECKHART, Mestre. Sobre o desprendimento. Trad. Alfred J. Keller. São Paulo: Martins Fontes, 2004. 
FLORIÊNSKI, Pavel. A perspectiva inversa. Trad. Neide Jallageas e Anastassia Bytsenko. São Paulo: Editora 34, 2012.

FLUSSER,Vilém. Bodenlos: uma autobiografia filosófica. São Paulo: Annablume, 2007.

2011.

Pós-história: vinte instantâneos e um modo de usar. São Paulo: Annablume,

FOUCAULT, Michel. A hermenêutica do sujeito. Trad. Márcio Alves da Fonseca \& Salma Tannus Muchail. São Paulo: Martins Fontes, 2014.

FREIRE, Paulo. Professora, sim; tia, não. Rio de Janeiro: Paz e Terra, 2013.

GAGNEBIN, Jean Marie. Lembrar, escrever, esquecer. São Paulo: Editora 34, 2006.

História e narração em Walter Benjamin. São Paulo: Perspectiva, 2011.

GALIMBERTI, Umberto. Psiche e techne: o homem na idade da técnica. Trad. José Maria de Almeida. São Paulo, 2006.

GROYS, Boris. Introdução à antifilosofia. Trad. Constantino Luz de Medeiros. São Paulo/Bauru: Edipro, 2013.

GUMBRECHT, Hans Ulrich. Produção de presença: o que o sentido não consegue transmitir. Trad. Ana Isabel Soares. Rio de Janeiro: Contraponto/Puc Rio, 2010.

GUNTRIP, Harry. "Minha experiência de análise com Fairbairn e Winnicott". Trad. Miguel A. de Mello Silva. In: Natureza Humana, v. 8, n. 2, p. 383-411, jul.-dez., 2006.

HAAR, Michel. Nietzsche et la métaphysique. Paris: Gallimard, 1993.

HABERMAS, Jürgen. Profils philosophiques et politiques. Paris: Gallimard, 1974.

HADOT, Pierre. Exercícios espirituais e filosofia antiga. Trad. Flavio Fontenelle \& Loraine Oliveira. São Paulo: É Realizações, 2014.

HAN, Byung-Chul. Sociedade do cansaço. Trad. Enio Paulo Giachini. Petrópolis: Vozes, 2015.

HOMEM, Maria Lucia. No limiar do silêncio da letra: traços da autoria em Clarice Lispector. São Paulo: Edusp/Boitempo Editorial, 2012.

HONNETH, Axel. Luta por reconhecimento: a gramática moral dos conflitos sociais. Trad. Luiz Repa. 2a . ed. São Paulo: Editora 34, 2011.

JASPE, Anselm. Crédito à morte. Trad. Robson J. F. de Oliveira. São Paulo: Hedra, 2013.

KAFKA, Franz. Contemplação e O foguista. Trad. Modesto Carone. São Paulo: Brasiliense, 1991.

KELSEN, Hans. Teoria pura do direito. 4르 ed. Trad. João Baptista Machado. Coimbra: Armênio Amado, 1976.

KHAN, M. Masud R. Quando a primavera chegar: despertares em psicanálise clínica. Trad. Claudia Starzysnki Bacchi. São Paulo: Escuta, 1991.

KOYRÉ, Alexandre. Estudos de história do pensamento filosófico. Trad. Maria de Lourdes Menezes. Rio de Janeiro: Forense Universitária, 1991.

LACAN, Jacques. O seminário. Livro 3. As psicoses (1955-1956). Trad. Aluísio Menezes. Rio de Janeiro: Jorge Zahar, 1988.

LÉVINAS, E. Totalidade e infinito. Trad. José Pinto Ribeiro. Lisboa: Edições 70, 2008. LITTLE, Margaret. Ansiedades psicóticas e prevenção: registro pessoal de uma análise com Winnicott. Trad. Maria Clara de Biase Fernandes. Rio de Janeiro: Imago, 1992.

LOPARIC, Zeljko. "Winnicott: uma psicanálise não-edipiana". Percurso, ano IX, n. 17, p. 41-47, 1997.

MADUENHO, Alexandre. "Transicionalidade, simbolização e transferência: processos de cura e amadurecimento no acompanhamento terapêutico". CADERNOS HabitAT, “Transferências", n. 1, v. 2, p. 31-53, 2012. 
NIETZSCHE, Friedrich. Além do bem e do mal. Trad. Paulo César de Souza. São Paulo: Companhia das Letras, 1992.

Ecce Homo: Como alguém se torna o que é. Trad. Paulo César de Souza. São

Paulo: Companhia das Letras, 2007.

Assim falou Zaratustra. Trad. Paulo César de Souza. São Paulo: Companhia das

Letras, 2011.

NUNES, Benedito. Ensaios filosóficos. Victor Sales Pinheiro (org.). São Paulo: Martins Fontes, 2010.

PARMÊNIDES. Pré-socráticos (Os Pensadores). Trad. José Cavalcante de Souza. São Paulo: Abril Cultural, 1978.

PESSANHA, Juliano Garcia. "Ensaio de filosofia fisionômica". In: Natureza Humana, v. 16, n. 1, p. 141-148, 2014. Disponível em: <http://revistas.dwwe.com.br/index.php/NH/article/view/80>. Acesso em nov. 2016.

. Testemunho transiente. São Paulo: Cosac Naify, 2015.

. \& MARQUES, Luciana Araujo. "Musil e Benjamin: a ética do homem sem qualidades e o empobrecimento da experiência". Cadernos Benjaminianos (UFMG) (no prelo).

PESSOA, Fernando. Prosa íntima e de autoconhecimento. Lisboa: Assírio \& Alvim, 2007.

PHILLIPS, Adam. Winnicott. Trad. Alessandra Siedschlag. Aparecida. São Paulo: Ideias \& Letras, 2006.

PORTINARO, Pier Paolo. La crisi dello jus publicum euro-paeum. Saggio su Carl Schmitt. Milão: Edizioni di Comunità, 1982.

RICOEUR, Paul. Tempo e narrativa, v. I, II. Trad. Claudia Berliner. São Paulo: Martins Fontes, 2012. 2014.

O si-mesmo como outro. Trad. Ivone C. Benedetti. São Paulo: Martins Fontes,

ROCHA, Angela Maria. Representações: coisas, pessoas e fazeres. Tese de livre docência. FAU/USP, 2012.

SAFRA, Gilberto. Hermenêutica na situação clínica: o desvelar da singularidade pelo idioma pessoal. São Paulo: Sobornost, 2006.

SCHELER, Max. La Situation de l'homme dans le monde. Trad. M. Dupuy. Paris: Aubier, 1951.

SCHMITT, Carl. "I tre tipi di pensiero giuridico". In: Le categorie del "político": saggi di teoria politica. Trad. Gianfranco Pierangelo Schiera Miglio. Bologna: Società editrice il Mulino, 1972.

O conceito do político. Trad. Alvaro L. M. Valls. Petrópolis, 1992.

TAYLOR, Charles. Argumentos filosóficos. Trad. Adail Ubirajara Sobral. São Paulo: Loyola, 2000.

As fontes do self: a construção da identidade moderna, $3^{\underline{a}}$. Trad. Adail Ubirajara e Dinah de Abreu Azevedo. São Paulo: Loyola, 2011.

TODOROV, Tzvetan. A beleza salvará o mundo. Trad. Caio Meira. Rio de Janeiro: Difel, 2011.

TSVETÁIEVA, Marina. Vivendo sob o fogo. Trad. Aurora Bernardini. São Paulo: Martins Fontes, 2008.

WINNICOTT, D. W. O brincar \& a realidade. Trad. José Octávio de Aguiar Abreu e Vanede Nobre. Rio de Janeiro: Imago, 1975.

Natureza humana. Trad. Davi Litman Bogomoletz. Rio de Janeiro: Imago, 1990. 2011 .

Tudo começa em casa, 5ª ed. Trad. Paulo Sandler. São Paulo: Martins Fontes, 
VERNANT, Jean-Pierre. As origens do pensamento grego. (4a. ed.). Trad. Ísis Borges B. da Fonseca. São Paulo: Difel, 1984. 